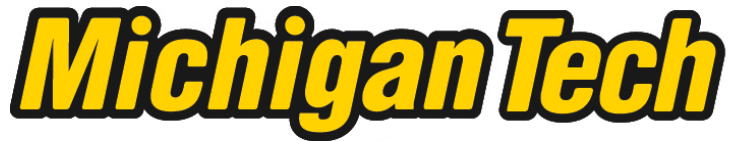 \\ Michigan Technological University Create the Future Digital Commons @ Michigan Tech
}

\section{Geophysical and geological analysis of the Collingwood Member of the Trenton Formation}

Ryan M. Banas

Michigan Technological University

Follow this and additional works at: https://digitalcommons.mtu.edu/etds

Part of the Geophysics and Seismology Commons

Copyright 2012 Ryan M. Banas

\section{Recommended Citation}

Banas, Ryan M., "Geophysical and geological analysis of the Collingwood Member of the Trenton Formation", Master's Thesis, Michigan Technological University, 2012.

https://doi.org/10.37099/mtu.dc.etds/312

Follow this and additional works at: https://digitalcommons.mtu.edu/etds

Part of the Geophysics and Seismology Commons 


\section{A GEOPHYSICAL AND GEOLOGICAL ANALYSIS OF THE COLLINGWOOD MEMBER OF THE TRENTON FORMATION}

By

Ryan M. Banas

\section{A THESIS}

Submitted in partial fulfilment of the requirements for the degree of MASTER OF SCIENCE

(Geophysics)

MICHIGAN TECHNOLOGICAL UNVIERSITY

2011

(c) 2011 Ryan M. Banas 
This thesis, "A Geophysical and Geological Analysis of the Collingwood Member of the Trenton Formation," is hereby approved in partial fulfillment of the requirements for the Degree of MASTER OF SCIENCE IN GEOPHYSICS.

Department of Geological and Mining Engineering and Sciences

Signatures:

Thesis Advisor

Wayne D. Pennington

Department Chair

Wayne D. Pennington

Date 


\section{TABLE OF CONTENTS}

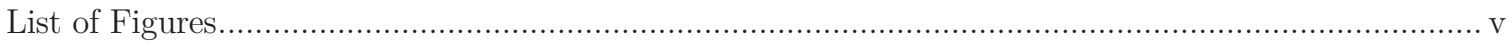

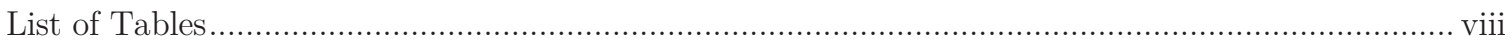

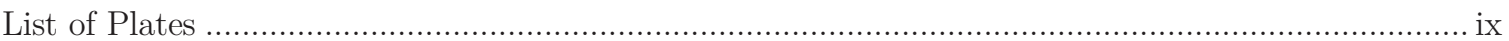

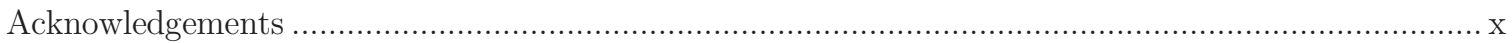

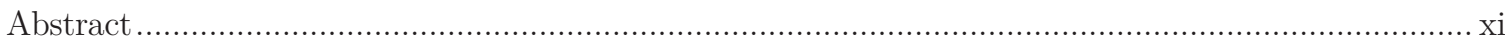

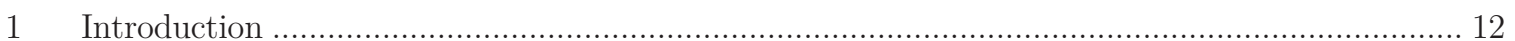

2 Geologic Framework of the Michigan Basin ............................................................................ 15

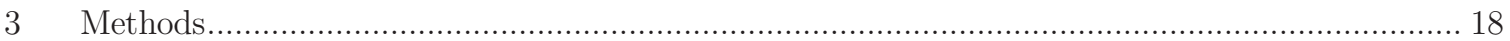

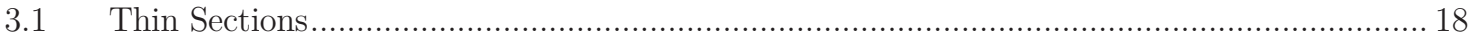

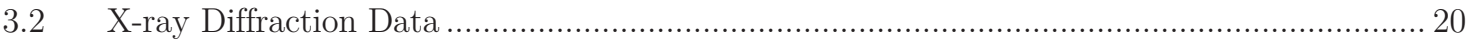

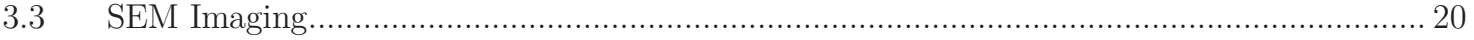

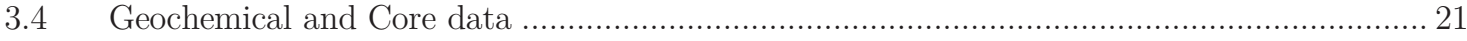

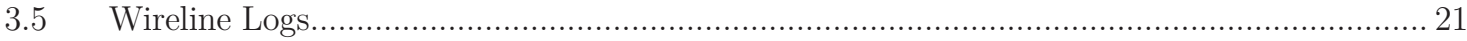

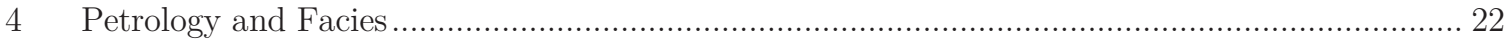

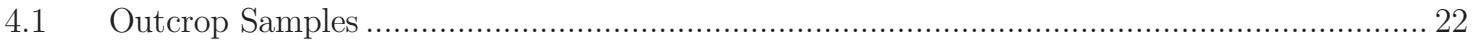

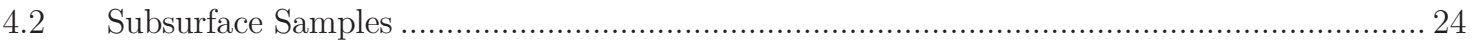

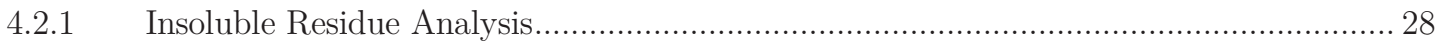

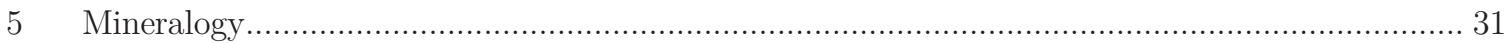

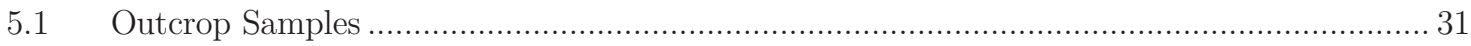

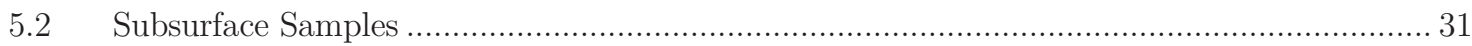

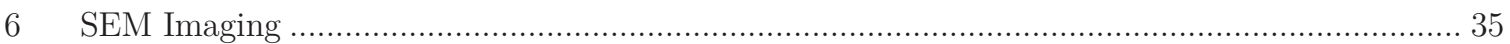

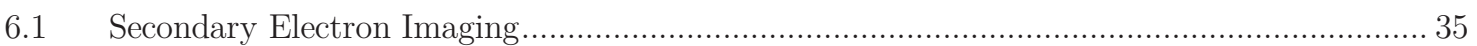

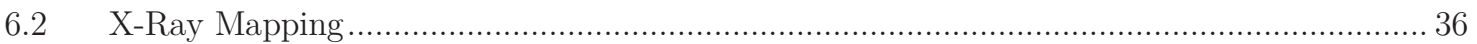

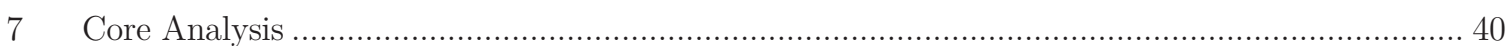

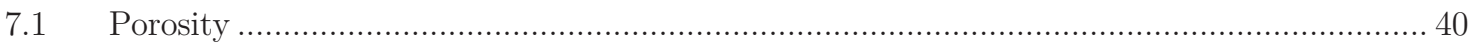

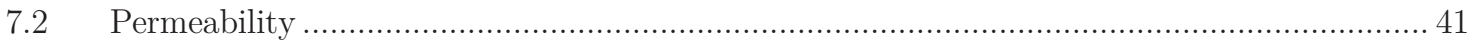

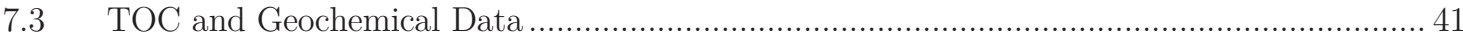

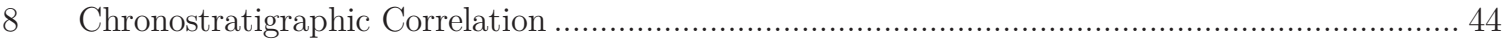

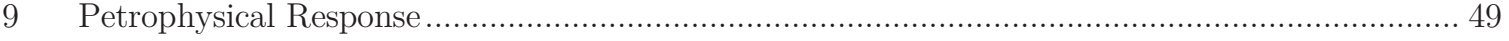

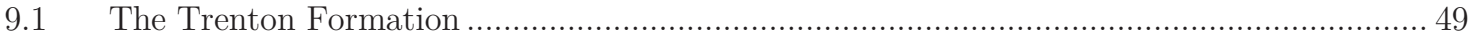




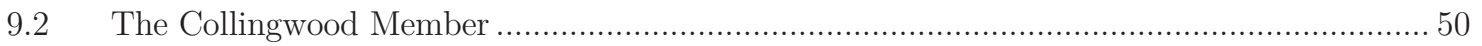

9.3 The Utica Shale

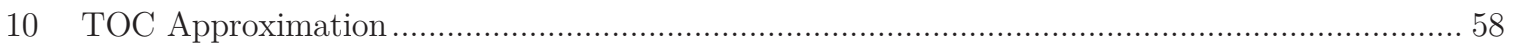

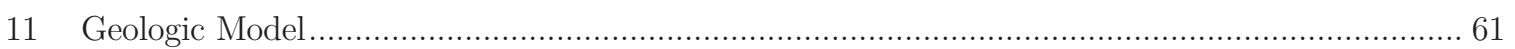

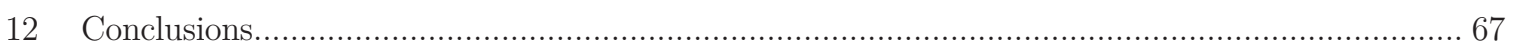

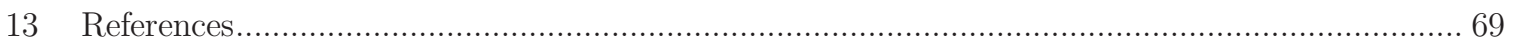

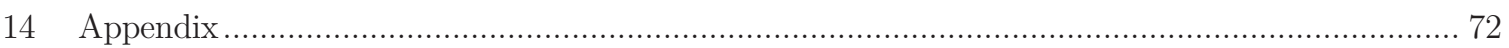


List of Figures

Figure 1.1: Collingwood outcrop region in Ontario, Canada along Georgian Bay. City of Collingwood marked in red, outcrop is shown as shaded region. ........................................................ 12

Figure 2.1: Geology of the Michigan Basin and surrounding structural features............................... 15

Figure 2.2: Stratigraphy of Collingwood and surrounding Ordovician units based on Correlation Of Stratigraphic Units of North America (COSUNA) (AAPG 1983-1986) and Michigan Department of Environmental Quality Geological Survey Division Map (Catacosinos et al., 2000) 16

Figure 3.1: USGS Outcrop Geology Map (Reed and Daniels, 1987) superimposed over an image of the Upper Peninsula of Michigan. Outcrop sample location indicated by the pin. Units described in accompanying text. Outcrop map data courtesy of U.S. Geological Survey. Google earth image courtesy of Google. 18

Figure 3.2: Outcrops, mapped on perspective view after Hussey (Hussey, 1952). Red dot (upper right) indicates Haymeadow Creek sample location. Google map image courtesy of Google. 19

Figure 4.1: Well core section (left) with four distinct facies highlighted (right). Hunt Energy Corporation, Winterfield Deep Unit A1 (API: 21-035-33680-0100), Clare County, MI. ......... 24

Figure 5.1: Carbonate and quartz contributions from JEM Petro Corp. Bruggers No. 3-7 (API: 21113-34078-0000), Missaukee County, MI. 32

Figure 5.2: Pattern matching of insoluble residue using Crystal Impact's Match! Software (XRD peaks and superimposed patterns shown). Sample from JEM Petro Corporation, Bruggers No. 3-7 (API: 21-113-34078-0000), Missaukee County, MI, 9,663' core depth.

Figure 5.3: Diagram depicting outcrop and well bore locations with available Collingwood samples in the Michigan Basin. Wells used in Hiatt's study are shown in black. Wells used in this study are shown in red. Wagner \#2 is unlabeled but shown in Delta County in the Upper Peninsula of Michigan. 34

Figure 6.1: X-Ray mapping regions 1 (left) and 2 (right). Points where EDS analysis performed are labeled. Images taken from a prepared thin section, JEM Petro Corporation, Bruggers No. 3-7 (API: 21-113-34078-0000), Missaukee County, MI, 9,666' core depth.................................... 37

Figure 6.2: Elemental yields x-ray map region 1, JEM Petro Corporation, Bruggers No. 3-7 (API: 21113-34078-0000), Missaukee County, MI, 9,666' core depth. 37

Figure 6.3: Point 3 EDS spectrum (left), Point 5 EDS spectrum (right), JEM Petro Corporation, Bruggers No. 3-7 (API: 21-113-34078-0000), Missaukee County, MI, 9,666' core depth......... 38

Figure 6.4: Elemental yields x-ray map region 2, JEM Petro Corporation, Bruggers No. 3-7 (API: 21113-34078-0000), Missaukee County, MI, 9,666' core depth. 38

Figure 7.1: Core measured porosity and TOC (solid lines) against carbonate and silica XRD mineralogy (I/C) computations (markers). JEM Petro Corporation, Bruggers No. 3-7 (API: 21-113-34078-0000), Missaukee County, MI. Core depth shown in feet.

Figure 7.2: Estimated Oil \& Gas Window for the Collingwood calculated from Trenton Formation Conodont Color Alteration Index Data (Hogarth and Sibley, 1985) and pyrolysis data. Temperatures shown are pyrolysis TMax values in degrees Celsius. The shaded region represents the extent of the Collingwood Member. 
Figure 8.1: Typical Trenton Gamma-Ray Signature showing TG-1 (as indicated by red X), from Miller Bros. \& Atlantic Richfield, Arcon \& Patton 1-34 (API: 21-147-38965-0000), St. Clair County, MI.

Figure 8.2: Selected wells in zone of thickness transition (Trenton Formation) highlighted in red (see figure 8.3). Black contours indicate burial depth (feet). Grey contours and colors indicate thickness of the Trenton Formation.

Figure 8.3: Gamma-ray, caliper, and resistivity logs for the Dart Oil and Gas Corporation, Dalrymple et al 1-16 (API: 21-143-34537-0000), Roscommon County, MI (left) and Marathon Oil Co., Weingartz et al 1-7 (API: 21-035-34611-0000), Clare County, MI (right). Well locations

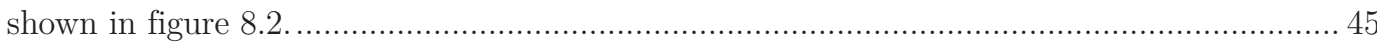

Figure 8.4: Correlative regions of gamma-ray in the Trenton Formation...................................46

Figure 8.5: Isopach map of the Trenton Formation with contours and colors indicating thickness in feet. White dotted line indicates proposed location of carbonate shelf margin as discussed in

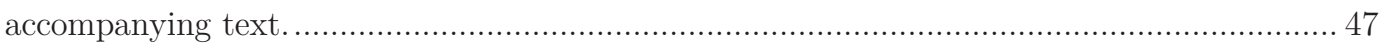

Figure 8.6: Top of Trenton Formation to TG-1 isopach (left) and TG-1 to top of Black River Formation isopach (right). The thicknesses values depicted by contours are shown in feet... 48

Figure 9.1: Trenton Formation gamma-ray amplitude trend shown. The gamma-ray value is computed as an average over the entire interval. Contours and colors indicate amplitude in GAPI. The highest gamma-ray amplitudes are shown in red. .49

Figure 9.2: Facies and core lithology depicted against wireline gamma-ray. JEM Petro Corporation, Bruggers No. 3-7 (API: 21-113-34078-0000), Missaukee County, MI. Log depth shown is 4'

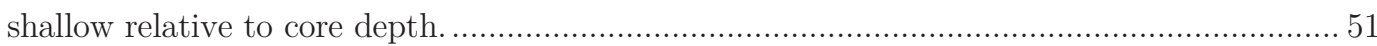

Figure 9.3: Collingwood Member gamma-ray amplitude trend shown. The gamma-ray value is computed as an average over the entire interval. Contours and colors indicate amplitude in GAPI. The highest gamma-ray amplitudes are shown in red. 52

Figure 9.4: Log suite from Collingwood to Black River interval. The characteristic resistivity doublet is visible in the second track. Energy Acquisition Corporation, North Michigan Land \& Oil Corp. 1-27 (API: 21-029-34824-0000), Charlevoix County, MI. .53

Figure 9.5: Log suite showing bulk density deviation from limestone standard $\left(2.71 \mathrm{~g} / \mathrm{cm}^{3}\right)$ shaded in red. Petoskey Exploration LLC, State Pioneer 1-3 (API: 21-113-59919-0000), Missaukee County, MI.

Figure 9.6: Full log suite, JEM Petroleum Corporation, Bruggers No. 3-7 (API: 21-113-34078-0000), Missaukee County, MI. Depth shown is log depth. Core data displayed depth shifted to match log depth.

Figure 9.7: Isopach of the Collingwood Member. Thickness depicted in contours and color in feet. Black dots on image are wellbore data points used to constrain contours. Minimum curvature gridding algorithm used. ..... .56

Figure 10.1: Linear regression computed for sonic transit time (from wireline logs) and TOC wt\% (from pyrolysis data) for both the JEM Bruggers 3-7 (API: 21-113-34078-0000), Missaukee County, MI, and Hunt Energy Winterfield Deep Unit A-1 (API: 21-035-33680-0000), Clare County, MI in the Collingwood interval............................................................... 58

Figure 10.2: DT vs. $\log _{10}$ (Deep Lateralog Resistivity) and corresponding regression line (blue). JEM Bruggers 3-7 (API: 21-113-34078-0000), Missaukee County, MI. .59 
Figure 10.3: Core measured TOC against TOC calculated via Passey's method and resulting regression to indicate fit. JEM Bruggers 3-7 (API: 21-113-34078-0000), Missaukee County, MI.

Figure 11.1: Gamma-ray logs from the Trenton Formation in the Michigan Basin. Log scale shown is 0-150 GAPI. Larger image shown in appendix (figure 14.1).

Figure 11.2: Stratigraphic cross-section as depicted by pink line shown. Cross section is leveled on TG1 as datum. Picks for Utica Shale, Collingwood, Trenton, Black River, and Glenwood formation tops shown. Larger image in appendix (figure 14.2).

Figure 11.3: Collingwood isopach (colors) superimposed on Trenton isopach (contours). All displayed values measured in feet. Red represents maximum thickness.......................................... 63

Figure 11.4: Structural features of the Michigan Basin that may be responsible for the deposition pattern of the Collingwood (shaded region). 64

Figure 11.5: Collingwood isopach (colored contours) superimposed on Trenton isopach (wireframe). Both units measured in feet.

Figure 14.1: Gamma-ray logs from the Trenton Formation in the Michigan Basin. Log scale shown is 0-150 GAPI..

Figure 14.2: Stratigraphic cross-section as depicted in figure 11.2. Cross section is leveled on TG-1 as datum. Picks for Utica Shale, Collingwood, Trenton, Black River, and Glenwood formations are shown. All measurements are in feet. 73 
List of Tables

Table 1: Quantitative $\mathrm{I} / \mathrm{I}_{\mathrm{C}}$ mineralogy for outcrop samples in the Collingwood and Trenton. .... 31

Table 2: Computed $\mathrm{I} / \mathrm{I}_{\mathrm{C}}$ mineralogy for subsurface samples from JEM Petro Corporation, Bruggers No. 3-7 (API: 21-113-34078-0000), Missaukee County, MI. Core depth shown.

Table 3: Approximate dolomite percentages in the Collingwood and Trenton (Michigan Basin) from XRD analysis $\left(\mathrm{I} / \mathrm{I}_{\mathrm{C}}\right)$. 34

Table 4: Spectral gamma-ray data summary from Hunt Energy Corporation, Winterfield Deep Unit A-1, (API: 21-035-33680-0100), Clare County, MI. 51 
List of Plates

Plate 4.1: Dyed surface outcrop samples shown in transmitted plane light ................................2 23

Plate 4.2: Hardground facies from JEM Petro Corporation, Bruggers No. 3-7 (API: 21-113-340780000), Missaukee County, MI at 9,660' core depth. .................................................. 25

Plate 4.3: Packed biomicrite (fossil debris) facies from JEM Petro Corporation, Bruggers No. 3-7 (API: 21-113-34078-0000), Missaukee County, MI at 9,661' core depth.

Plate 4.4: Laminated mud (siliceous micrite) and homogenized facies from JEM Petro Corporation, Bruggers No. 3-7 (API: 21-113-34078-0000), Missaukee County, MI at 9,666' and 6,671' core depth respectively. 27

Plate 4.5: Insoluble residue from JEM Petro Corporation, Bruggers No. 3-7 (API: 21-113-34078-0000), Missaukee County, MI at 9,663' core depth (siliceous micrite facies) under reflected light. 29

Plate 6.1: Secondary Electron Images from JEM Petro Corporation, Bruggers No. 3-7 (API: 21-11334078-0000), Missaukee County, MI, 9,669' core depth (region of highest measured porosity). 
Acknowledgements

I would like to thank SPWLA for the generous grant to conduct this research. Special thanks to William B. Harrison (Michigan Geological Repository for Research and Education at Western Michigan University) for supplying well core and data. I also would like to thank Wayne

Pennington, Roger Turpening, James Wood, Ted Bornhorst, George Robinson, and Robert Barron at Michigan Technological University for their support. 


\begin{abstract}
The Collingwood Member is a mid to late Ordovician self-sourced reservoir deposited across the northern Michigan Basin and parts of Ontario, Canada. Although it had been previously studied in Canada, there has been relatively little data available from the Michigan subsurface. Recent commercial interest in the Collingwood has resulted in the drilling and production of several wells in the state of Michigan.

An analysis of core samples, measured laboratory data, and petrophysical logs has yielded both a quantitative and qualitative understanding of the formation in the Michigan Basin. The Collingwood is a low permeability and low porosity carbonate package that is very high in organic content. It is composed primarily of a uniformly fine grained carbonate matrix with lesser amounts of kerogen, silica, and clays. The kerogen content of the Collingwood is finely dispersed in the clay and carbonate mineral phases.

Geochemical and production data show that both oil and gas phases are present based on regional thermal maturity. The deposit is richest in the north-central part of the basin with thickest deposition and highest organic content. The Collingwood is a fairly thin deposit and vertical fractures may very easily extend into the surrounding formations. Completion and treatment techniques should be designed around these parameters to enhance production.
\end{abstract}




\section{Introduction}

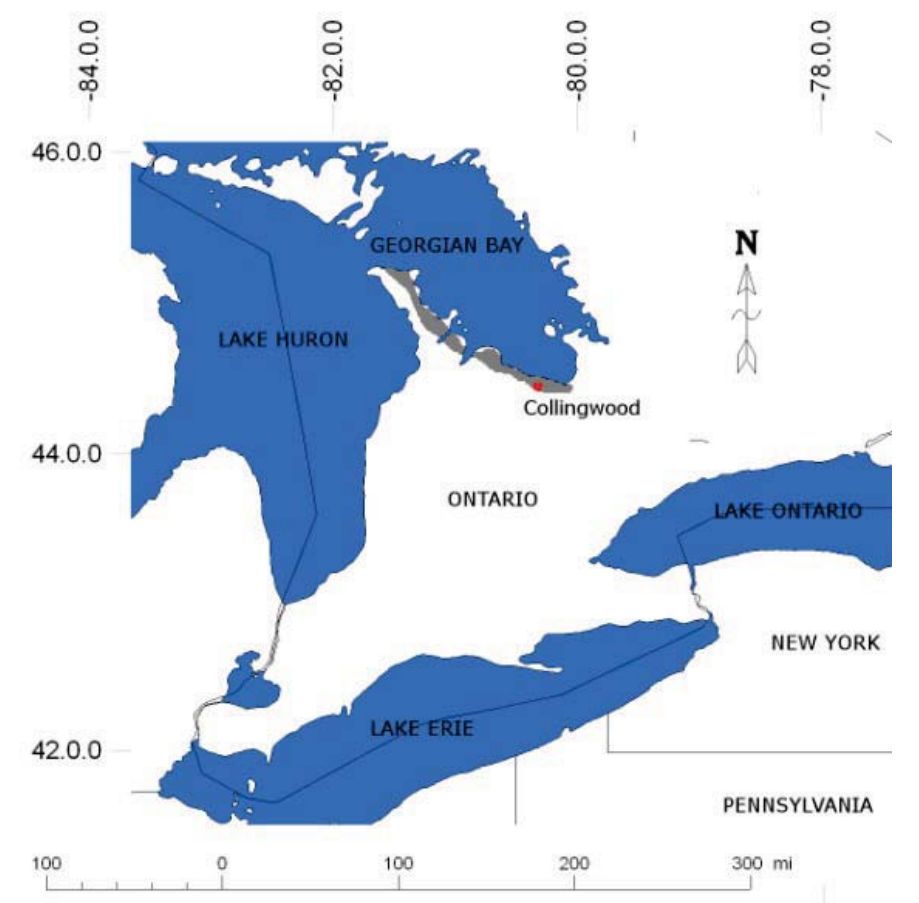

Figure 1.1: Collingwood outcrop region in Ontario, Canada along Georgian Bay. City of Collingwood marked in red, outcrop is shown as shaded region.

The Collingwood Member of the Trenton Formation (also known as the Collingwood Shale) is a mid to late Ordovician carbonate package deposited across the northern half of the Michigan Basin and regionally in Ontario, Canada (figure 1.1). Where it is present, it occupies the uppermost section of the Trenton Formation, and is overlain by the Utica Shale. It was named after Collingwood, Ontario, Canada where it was originally identified as an oil shale by Henry Youle Hind of the University of Toronto in 1857 (Tuffnell and Ludvigsen, 1984). The Collingwood was subsequently mined for hydrocarbons from 1859 to 1861 near Craigleith, Ontario with reported values of 250 gallons of crude oil extracted from 30-36 tons of bituminous shale (Tuffnell and Ludvigsen, 1984). The mining stopped in 1861 when sources of cheaper, more conventional oil were found in other areas of Ontario (Harris, 1985).

In 1979, the Canadian province of Ontario established an incentive to obtain energy self-sufficiency of $37.5 \%$ by 1995 (Cochrane, 1984). As a result of this incentive the Hydrocarbon Energy Resources Program (HERP) was initiated in 1981 to review and catalog all of the potential hydrocarbon resources in the Ontario subsurface, including oil shale, coal, and conventional oil and gas. The Oil Shale Assessment Project (OSAP) was launched as a component of the HERP and was conducted by the Ontario Geological Survey (Churcher, et al., 1991). The HERP and OSAP resulted in a number of 
results in the form of core, geophysical, and geochemical data that have since been published by many authors in Canada.

The Collingwood in the Michigan Basin was studied during the mid 1980's by Hiatt at Michigan Technological University. Her study utilized well core provided by Shell and geophysical well logs from the very northern part of the Michigan Basin. The findings were numerous including petrological analysis of thin sections, XRD and XRF analysis, and development of a geologic model of deposition. Wireline data however was limited as was the geographic extent of the well cores provided in the study. A very important conclusion was made by Hiatt in the Michigan Basin, demonstrating that Collingwood there is a fine grained carbonate source rock (Hiatt, 1985).

Prior to the first quarter of 2009 there had not been any wells deliberately drilled into the Collingwood as a potential reservoir target. This changed on July $30^{\text {th }}, 2009$ when Encana Corporation filed a permit for the State Pioneer \#1-3 in Missaukee County. The well was completed with a horizontal leg, stimulated with hydraulic fracture, and then production tested in March, 2010. Data available from the Michigan Department of Environmental Quality (MDEQ) indicate that the first few months of testing resulted in gas flow rates between 1.43 and 3.188 MMCF/D with small contributions of water and condensate (MDEQ Online Oil and Gas Database, 2010; Harrison, 2011).

The attention garnered from the State Pioneer well resulted in a record breaking mineral lease auction for the State of Michigan auction in May of 2010. The total sum netted of $\$ 178$ million is the largest in the state's history and is nearly equal to the entire total of lease sales since 1929, \$190 million (Fox, 2010). The State Pioneer well was eventually shut in (June $\left.1^{\text {st }}, 2010\right)$, likely due to low gas flow rates and high water production (MDEQ Online Oil and Gas Database, 2010).

The subsequent lease auction in October of 2010 resulted in a net sale of only $\$ 10$ million, a large decrease from May's total of $\$ 178$ million (Awdish, 2011). In the time since the completion of the State Pioneer \#1-3, two other wells have been drilled and completed in the Collingwood, one by Encana Corporation (St. Koehler \& Kendall 1-27HD) and the other by Atlas Oil \& Gas (Lucas \#113). In addition to these, a large number of wells targeting the Collingwood are currently in the permitting or drilling stage at the time of this writing (MDEQ Online Oil and Gas Database, 2010).

An obvious interest in the Collingwood is demonstrated by the large capital investment; this may be partially due to the popular association of the formation with the current emphasis on shale plays in the United States. Nonetheless, it remains fairly poorly understood with the only publicly available study in the Michigan Basin being the one conducted by Hiatt in 1985. In addition, the apparently poor long term performance of the first wells to be completed suggests that a more thorough understanding of the Collingwood Member is necessary to make it an economical play. 
In this study core data from three deep basin wells and a large number of wireline logs were used in conjunction with all previously published data in order to fully characterize the Collingwood in Michigan. The core was made available through the Michigan Geological Repository for Research and Education (MGRRE), of Western Michigan University. A full scale approach was taken employing analyses including: petrographic, x-ray diffraction mineralogy, SEM imaging, core, geochemical, and petrophysical interpretation and mapping. From this data, conclusions can be drawn about the intrinsic properties of the formation and its geologic history. 


\section{Geologic Framework of the Michigan Basin}

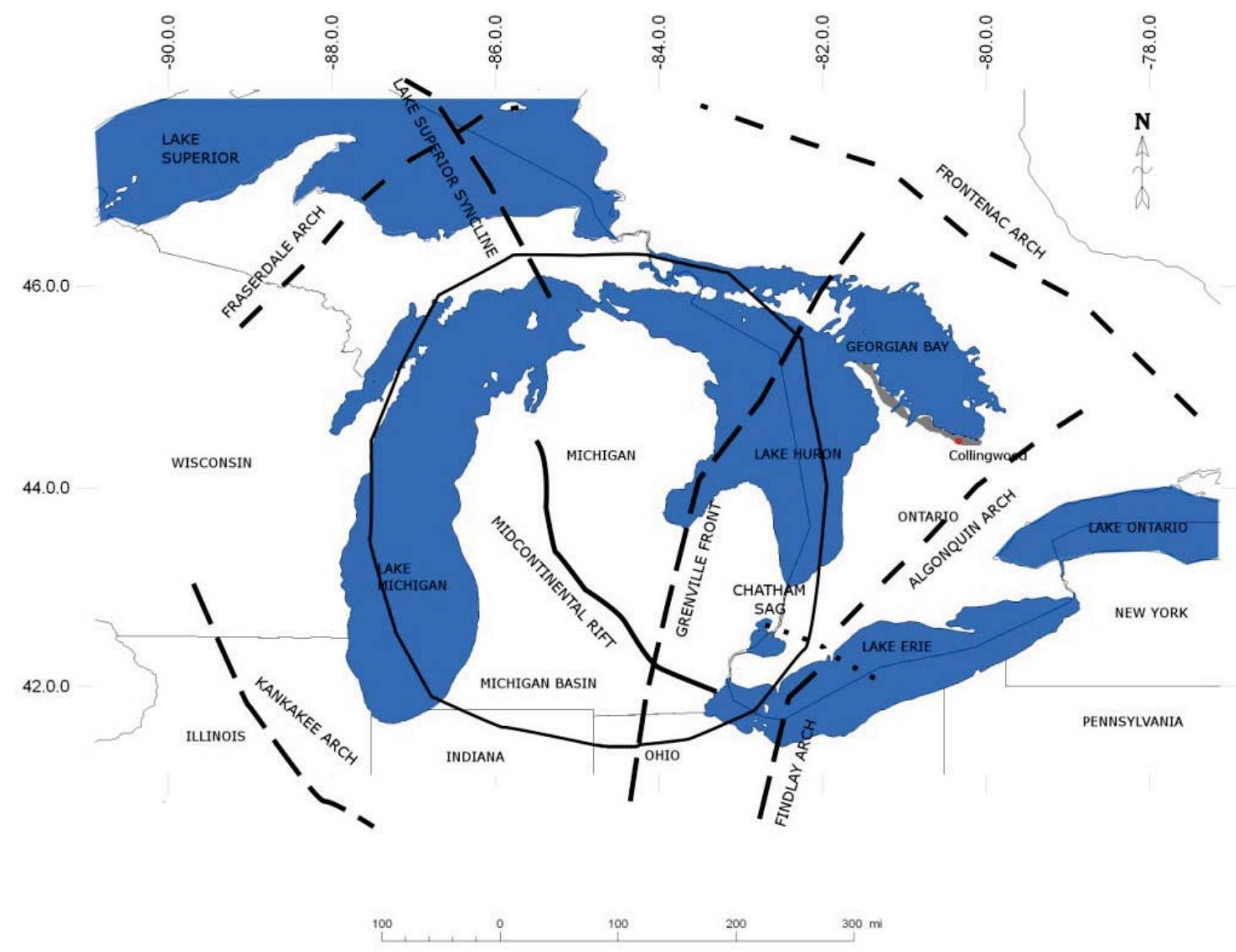

Figure 2.1: Geology of the Michigan Basin and surrounding structural features.

Several authors have published theories for the formation of the Michigan Basin. Quinlan states that "although numerous hypotheses have been suggested for the origin of this structure [the basin], including thermal contraction, deep crustal metamorphism, and lithospheric stretching, no consensus has been reached concerning the tectonic development of the basin" (Quinlan, 1987). Cross et al suggest that basins generally form in response to processes such as heating events and tectonic loading (Cross, et al., 1995).

Catacosinos et al show that, although the Michigan Basin's origins are not well understood there is a plausible model (Catacosinis et al., 1991). They suggest that the development of the basin is likely related to a two part process. The first was the origin and primary evolution of the basin from midcontinental rifting approximately 1 billion year ago in the Precambrian. Post rifting, they provide for the formation of a sag basin from thermal subsidence that occurred about 520 million years ago in the late Cambrian. Catacosinos et al also note that other "coeval cratonic basins" have formed from extensional regimes and thermal events associated with the breakup of a late Precambrian supercontinent (Catacosinis et al., 1991). 


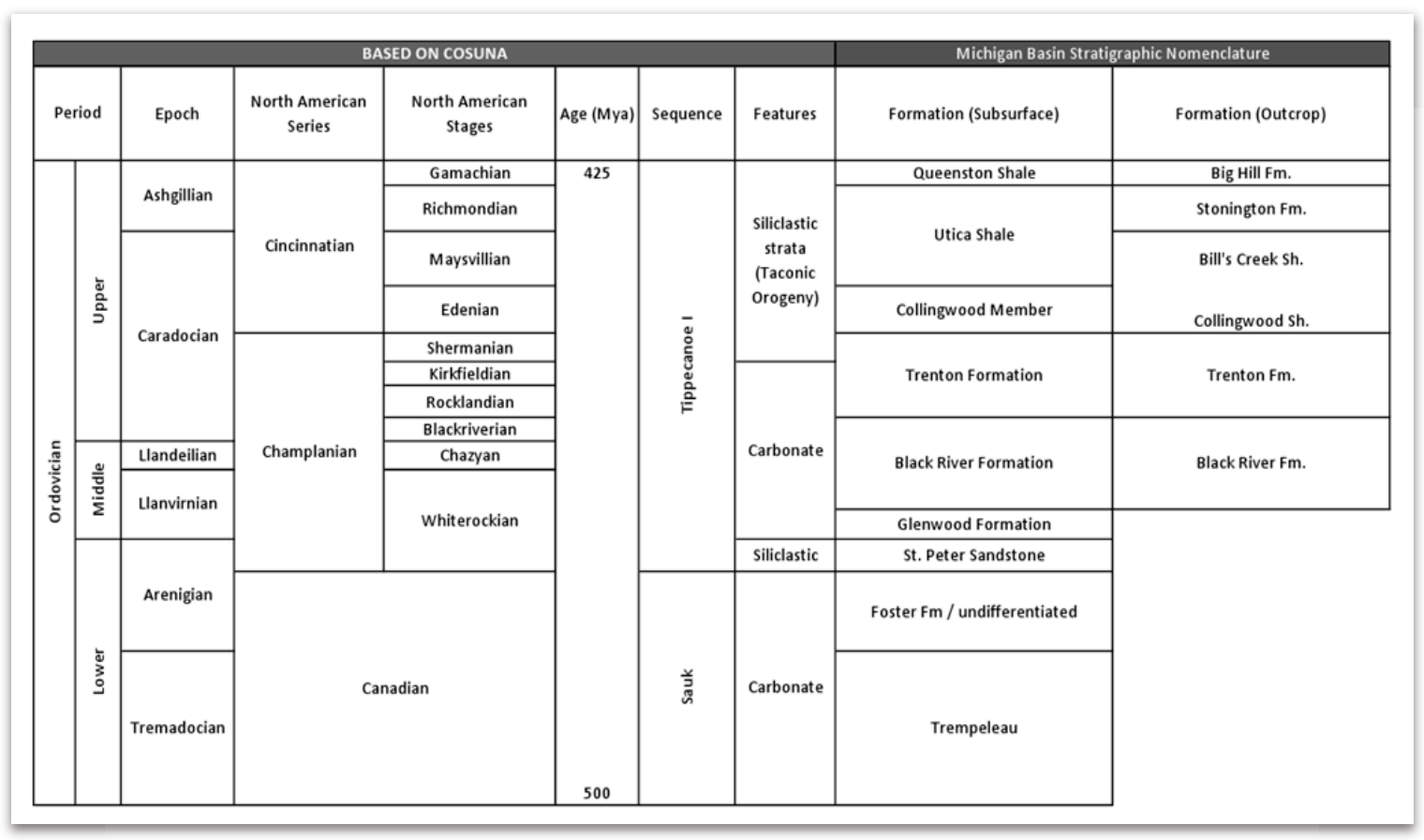

Figure 2.2: Stratigraphy of Collingwood and surrounding Ordovician units based on Correlation Of Stratigraphic Units of North America (COSUNA) (AAPG 1983-1986) and Michigan Department of Environmental Quality Geological Survey Division Map (Catacosinos et al., 2000)

The Michigan Basin itself is a rather basic bowl shaped depression that is slightly elongated in the NW-SE direction, approximately 300 miles in diameter, and about 16,000 feet deep (Howell and Van der Pluijm, 1990). Surrounding it are additional structures such as the Kankakee and FindlayAlgonquin Arches in the south and Fraserdale and Frontenac Arches in the north (figure 2.1). These arches serve as boundaries between the Michigan Basin and surrounding basins such as the Illinois and Appalachian.

At the beginning of the Ordovician, the present day North American continent (Laurentia) lay approximately at the equator separated from the newly forming Taconic Arc by the Iapetus Ocean. As time passed into the late Ordovician the Taconic Orogeny occurred, where the island arc contacted the continent resulting in uplifting and mountain building. Closure of the Laurentian-Taconic margin also resulted in the restructuring of the Iapetus Ocean and alteration of the seas.

These orogenic actions greatly affected the Michigan Basin, not only structurally from the collision, but also contributed to changes in ocean currents, water oxygenation and sediment types. All of these changes are visible in cores across the Michigan Basin, where one environment in the middle Ordovician has significantly changed by the late Ordovician. One example of this is the rather abrupt influx of the Utica Shale from the Queenston delta over the thick carbonate deposits of the Trenton and Black River. It has also been suggested that the Appalachian orogenic activity may be responsible for the events of subsidence that have occurred in the Michigan Basin, specifically a period of tectonic subsidence during the middle Ordovician in and around the time of Collingwood deposition (Howell 
and Van der Pluijm, 1990). Catacosinos et al note that "major basinal subsidence" began during the Early Ordovician and had created the "distinctive basinal configuration" by the end of the Early Ordovician (Catacosinis et al., 1991).

The particular profile of subsidence suggested by Howell and Van der Pluijm for the sequence of 438$474 \mathrm{MYa}$ is a transition from (the first) basinal centered subsidence in the Middle Ordovician to regional eastward tilted subsidence in the Late Ordovician (Howell and Van Der Pluijm, 1999). The change in subsidence profile is attributed to Taconic orogenic activity with the eastward subsidence being late Taconic in time (Howell and Van Der Pluijm, 1999). Subsidence is considered a linear process by Howell and Van der Pluijm in the Ordovician. Wilson et al also note that the basin typically is considered to have a uniform subsidence pattern throughout geologic history of about 1020 meters per million years, with the exception of the Late Silurian and Early Devonian (Wilson et al., 2001).

More specific chronostratigraphic units for the time frame of the Collingwood and surrounding strata are given as the Shermanian and Edenian stages of the Champlainian and Cincinnatian series of the Upper Ordovician (figure 2.2) (Keith, 1988). Each is given respectively for the Trenton and Collingwood, with the deposition of the Collingwood starting just about as Edenian time began. Shown by Keith, according to COSUNA charts, the south-western half of the Michigan Basin was in a subtidal facies of clean carbonate rocks and the north-eastern half part of a subtidal facies of argillaceous carbonates or interbedded carbonates and shale (Keith, 1988). As time progressed into the Edenian, water levels rose resulting in a deeper subtidal facies with clastic rocks prograded over carbonates, likely due to the input from the Taconic Orogeny as spillover from the Taconic foreland basin. Eventually in Maysvillian time, that of the Utica, the entire basin was a deep subtidal facies composed entirely of shale (Keith, 1988).

It is also known that in the Michigan Basin, wrench faulting has been observed and typically follows a NW-SE trend with a complementary SW-NE trend (Prouty, 1988). Catacosinos et al state the origins of this trend are likely due to a compressive event in the NW-SE direction that resulted in the structural lineaments along with other features such as the Howell anticline (Catacosinos et al., 1991). Hinks suggests that this wrench faulting may also lead to subsequent Riedel shearing and fault blocks in higher stratigraphy responsible for many of the hydrothermally dolomitized reservoirs in the basin (Hinks, 2011). It is important to contrast the differences in the deep rooted and shallow features associated with this type of faulting.

Other curiosities exist in the Michigan basin, such as the mid continental rift system that has been identified and mapped via a Bouguer gravity anomaly. Proximity to this rift may affect thermal maturity of deposits suggested by pyrolysis data in this study. Additionally, the Grenville Front is noted by Wilson et al as being important to Ordovician deposition patterns, as it produces a basement high in the basin (Wilson et al., 2001). 


\section{Methods}

\subsection{Thin Sections}

Outcrop samples for thin sections were obtained from the Haymeadow Creek area north of Rapid River in the Upper Peninsula of Michigan (lat/long 46.021775, -86.859305). This general sample location was selected based on two criteria: (1) it was the only accessible surface outcrop area of the Collingwood in the Upper Peninsula (via stream cuts) and (2) it had been identified in a field trip guide published by Hussey (Hussey, 1952) that outlined Ordovician age outcrops in the EscanabaStonington area and in the USGS Bedrock Geology map for the Upper Peninsula of Michigan (Reed and Daniels, 1987).

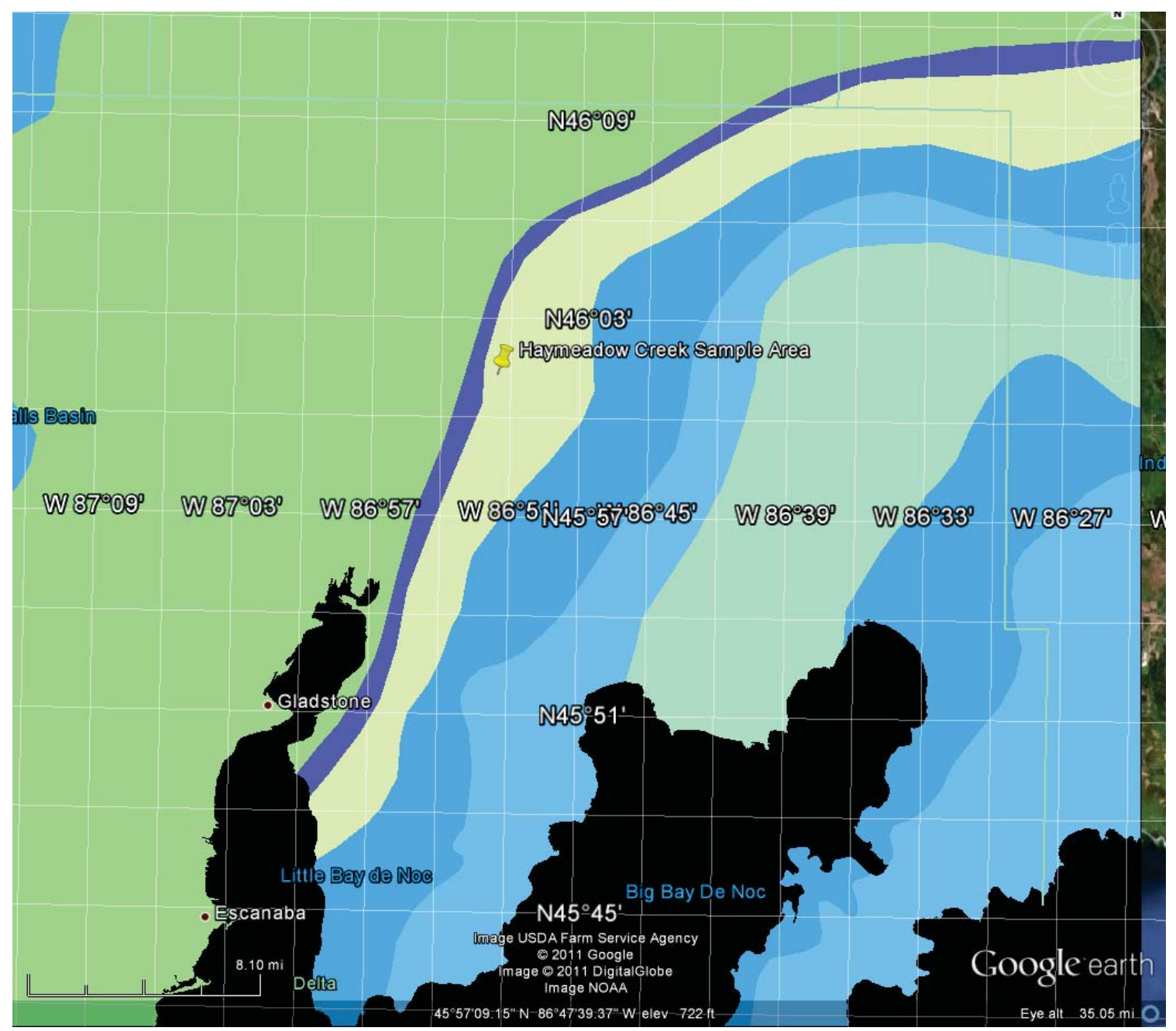

Figure 3.1: USGS Outcrop Geology Map (Reed and Daniels, 1987) superimposed over an image of the Upper Peninsula of Michigan. Outcrop sample location indicated by the pin. Units described in accompanying text. Outcrop map data courtesy of U.S. Geological Survey. Google earth image courtesy of Google. 


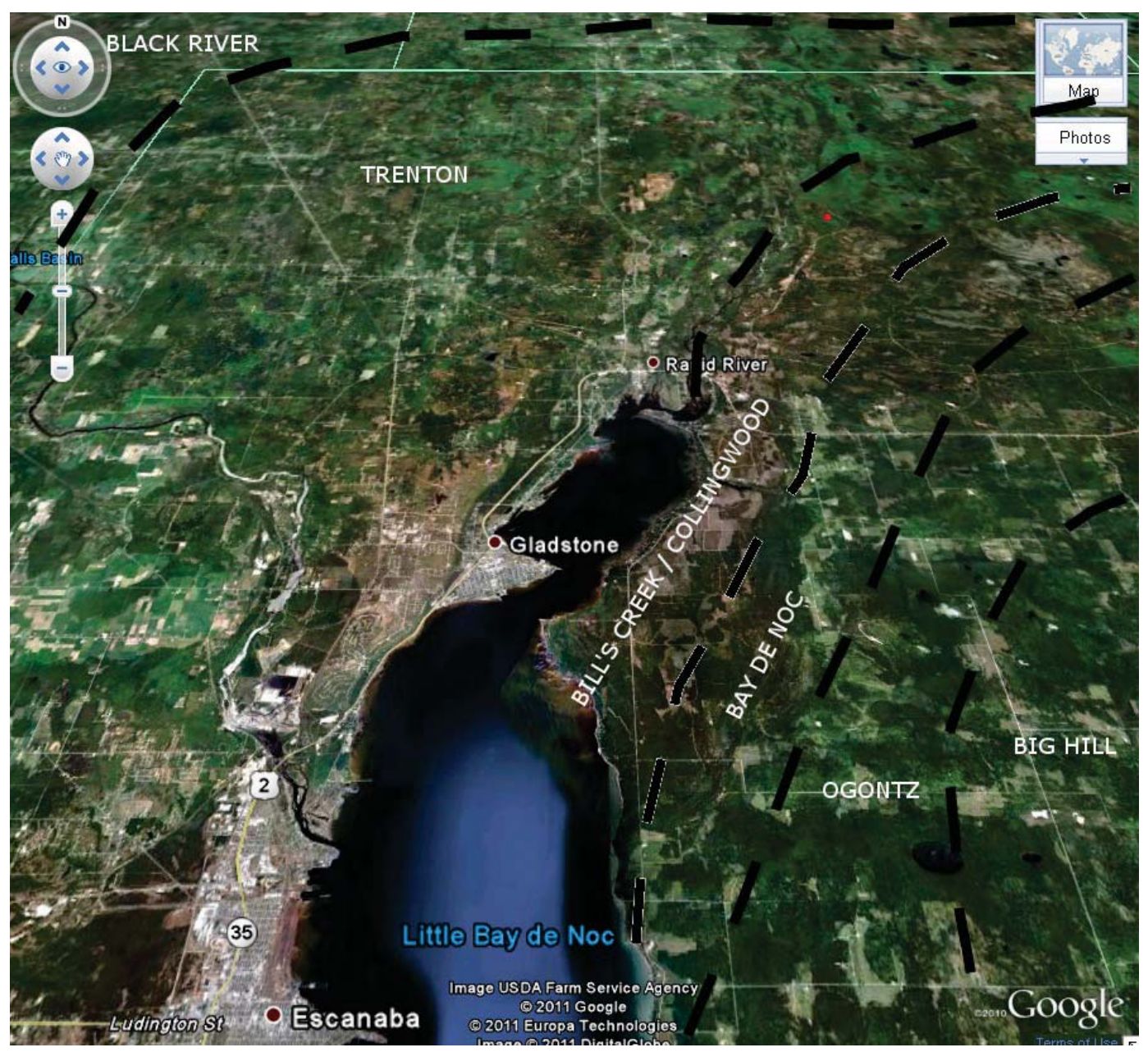

Figure 3.2: Outcrops, mapped on perspective view after Hussey (Hussey, 1952). Red dot (upper right) indicates Haymeadow Creek sample location. Google map image courtesy of Google.

There is some ambiguity concerning the outcrop exposures in the Michigan's Upper Peninsula. In the USGS outcrop map (figure 3.1), the thin purple strip to the west of the sample area (indicated by the pin) is identified as the Collingwood Limestone and the sample area is within the area identified as the Utica Shale (tan). O the other hand, in Hussey's map (figure 3.2) the Collingwood is not specifically identified as an outcrop region, but is labelled as, Bill's Creek unit, of which the Collingwood is a part. This presents a dilemma as to whether or not our surface sample location is within the Bill's Creek Shale, Collingwood Limestone, or Utica Shale.

Subsurface samples were obtained from the JEM Bruggers 3-7 core at MGRRE. After examining the core, chips were extracted from the Utica Shale, Collingwood Member and Trenton Formation at 14 points in varying sizes suitable for x-ray diffraction (XRD) and other analyses. After small samples were crushed for XRD analysis, large chips that remained were sorted by facies for thin section preparation. In total, 5 samples were selected from 4 unique facies. They were fixed to glass slides with optical grade epoxy and subsequently polished with silica carbide grit until suitable for viewing under transmitted plane light in a petrographic microscope. 
Some samples were stained with alizarin red (1\%) and potassium ferrocyanide (10\%) dye solutions mixed with a hydrochloric acid solution (for etching) in order to characterize carbonate content. Specifically, all surface samples were stained, but two subsurface samples were left unstained after it was found that the process resulted in poor transmitted light through the dark, kerogen rich lithology. In addition to the samples prepared at Michigan Tech, several existing thin sections from the JEM Bruggers 3-7 well were viewed from collections at MGRRE.

\subsection{X-ray Diffraction Data}

Samples for x-ray diffraction were obtained from the sources listed in the preceding section with the addition of two samples of Trenton Limestone recovered from Groos Quarry in Escanaba, MI. These samples were extracted from the upper portion of the quarry as a baseline comparison to the Collingwood.

To prepare the XRD samples, rock chips were pulverized in a steel apparatus and then transferred to a ceramic mortar and pestle until reduced to a fine powder. This powder was then affixed to double sided tape on a glass slide, levelled and inserted into the x-ray diffraction instrument. Samples were run with a $\mathrm{CuK}_{\alpha}$ filament $(1.5418 \mathrm{~A}$ ) in varying degree ranges (as appropriate) at a $2 \mathrm{deg} / \mathrm{min}$ continuous rate. Peak correlation and $\mathrm{I} / \mathrm{C}\left(\mathrm{I} / \mathrm{I}_{\mathrm{C}}\right)$ quantitative calculations were produced with Crystal Impact's Match! XRD analysis software and International Centre for Diffraction Data (ICDD) databases.

In addition to XRD studies of crushed rock samples, a residual non-carbonate analysis was conducted on a $6 \mathrm{~g}$ sample of the Collingwood from the JEM Bruggers 3-7 well $(9,663$ ' core depth) by treating it with hydrochloric acid, hydrogen peroxide, and acetic acid for a week in order to dissolve the carbonate content. During treatment the sample was passively disaggregated in order to increase the reaction rate.

\subsection{SEM Imaging}

Two chips from the JEM Bruggers 3-7 well at core depth 9,669' (region of highest porosity) were chosen to prepare an SEM puck. These samples were left whole and submerged in optical grade epoxy to set. The puck was then polished with silica carbide grit and diamond paste to render a flat, reflective surface. Additional coatings of carbon and platinum were applied to the sample in order to enhance imaging. Secondary electron (SE), or low energy, inelastic scatter images were then taken of these samples at various magnifications.

A thin section prepared at core depth 9,666' of the siliceous micrite facies (region of highest TOC) from the JEM Bruggers 3-7 well was also coated with carbon and used for x-ray mapping and EDS analysis via SEM. Quantitative analysis in EDS images was computed via 4Pi Analysis' Revolution software. SE images were subsequently processed via ImageJ using threshold analysis for porosity calculations. 


\subsection{Geochemical and Core data}

Pyrolysis data at one foot intervals along with measured physical core properties (i.e. $\phi$ (porosity), K (permeability)) were provided through MGRRE for the JEM Bruggers 3-7, JEM Weingartz 1-7 and Hunt Winterfield Deep Unit A1 wells. Chromatography data was also provided through the Michigan DEQ Office of Oil, Gas and Minerals for the Encana St. Koehler \& Kendall 1-27HD. Thermal models for the Trenton Formation in the Michigan Basin were constructed from Conodont CAI data (Hogarth and Sibley, 1985).

\subsection{Wireline Logs}

Formation tops, well location and raster image databases were obtained from MDEQ online in Microsoft Access (mdb) format. These access databases were then converted to SQL format and imported into mysql in order to perform multi database searches. SQL scripts were written in order to locate specific wells which intersected the Collingwood by cross linking results from the formation tops database, identifying Utica and Trenton picks with the well locations and spatial coordinates, and scanned well logs from the raster image database. These results were then tabulated and well logs that were not already available in LAS format (from MDEQ or Michigan Tech) were subsequently digitized using Neuralog software.

In addition to these Collingwood intersecting wells, a suite of existing well logs available at Michigan Tech, from wells that intersected the Trenton were added to aid in chronostratigraphic correlation of the Collingwood horizon and analysis of the Trenton Formation. Mud logs were also found to be available for several wells during this search and subsequently gathered for analysis. Additional mud logs were provided via W.B. Harrison's 2010 publication of organic shales in the Michigan Basin (Harrison, 2010). 


\section{Petrology and Facies}

\subsection{Outcrop Samples}

Rock samples were collected in the deepest section of the Bill's Creek shale as indicated by the outcrop region marked by Hussey (Hussey, 1952). This region should correspond to the Collingwood Member as it lies directly above the Trenton Limestone outcrop area exposed at the Groos Quarry and Chandler Falls locales in Escanaba, MI as well as in the Whitefish River north of Rapid River, MI. The surface samples that were acquired were determined to be of a significantly different lithology than those observed in drill cores retrieved from the subsurface of the basin. The samples obtained in this study are primarily buff grey dolomitic limestones absent of kerogen. The discrepancy between surface and subsurface lithology may be attributed to inaccuracies in Hussey's approximation of Ordovician outcrops, or to the possibility of a different depositional environment that was present in this area.

Two distinct lithologies were observed in samples acquired from the Haymeadow Creek bed. The stratigraphically higher of the two is a very competent chocolate brown dolostone. Using the Folk classification (Carozzi, 1993, p. 106-109; Flugel, 2010, p. 339-368), employed for all samples hereon, this lithology classifies as an equigranular anhedral to subhedral grain-supported dolostone with a matrix grain size ranging from 25-125 microns. The rock is very homogeneous and semi sutured with a xenotopic mosaic and very few fossils. The porosity in this rock is intergranular and is easily visible in thin section. The dolomite content appears to be ferroan exhibiting a turquoise blue tint after staining. Authigenic pyrite was observed sparsely in well formed relatively large cubic crystals. This lithology may correspond to a dolomite cap facies that is associated with the top of the Trenton Formation regionally in the Michigan Basin. An image of this lithology is shown in plate 4.1, image 1.

The stratigraphically lower lithology sampled is a buff grey, highly fossiliferous limestone in the majority of the samples collected. This lithology classifies as a dolomitic packed biomicrite with a porphyrotopic mosaic. It exhibits porphyroidal neomorphism of dolomite and coalescive neomorphism of calcite. In the micrite matrix, isolated, euhedral, floating dolomite rhombs are easily visible and appear ferroan from staining. The rock is highly fossiliferous with a large spectrum of Ordovician fauna including graptolites, gastropods, conodonts, crinoids, byrozoans, echinoderms, and ostracods. The fossil fragments physically appear angular and well preserved suggesting a lack of high energy transportation from their source. This lithology also contains authigenic pyrite very similar to the dolostone lithology in frequency of occurrence, crystal habit and size.

In plate 4.1, image 2, section A, fine grained calcite crystals exhibit coalescive neomorphism by recrystallization of larger crystals dyed in red. Siliceous content found from other analyses may be present in this section as opaques. Section B shows unstained and partially stained (ferroan) saddle dolomite in contrast to the calcite of section A. 

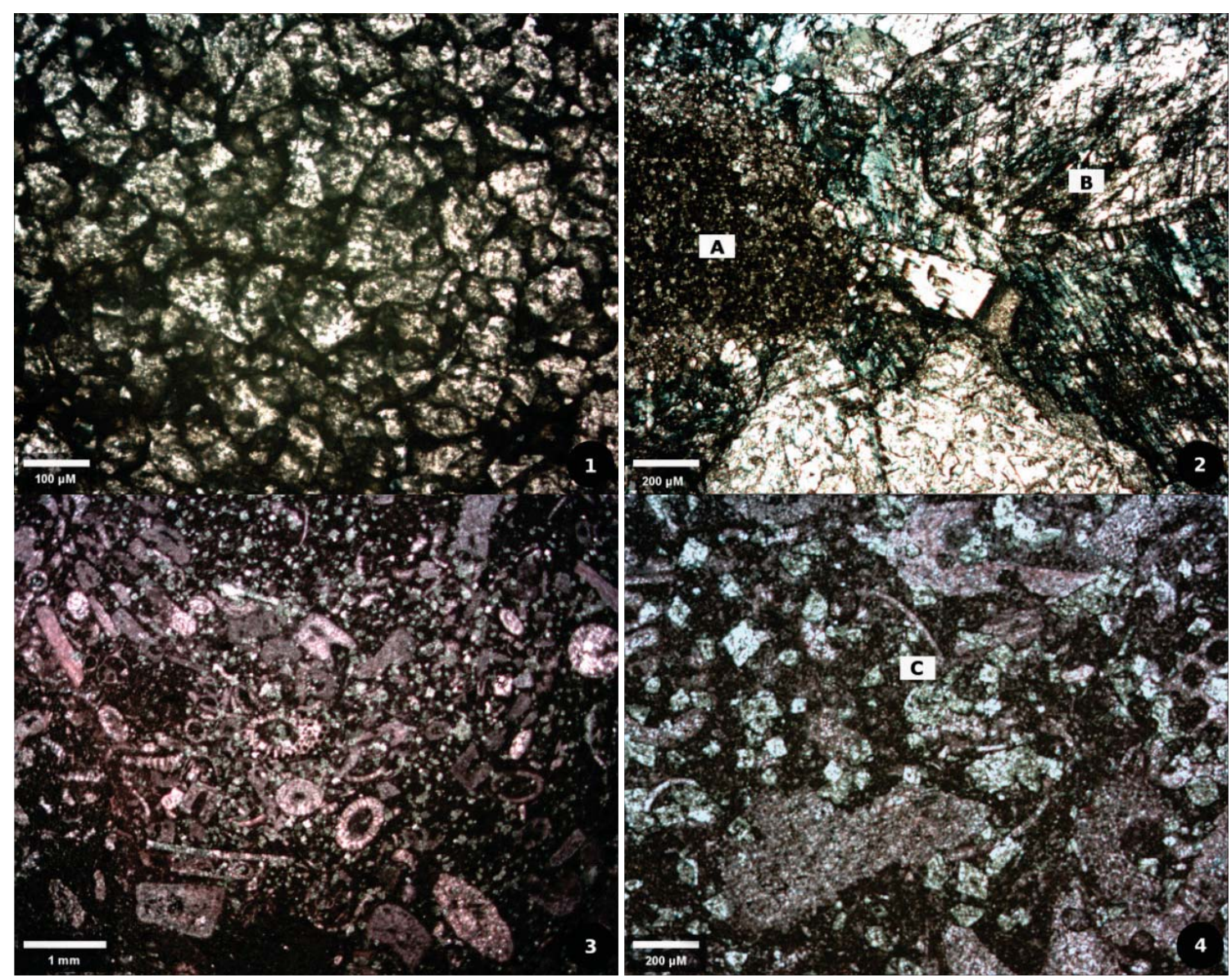

Plate 4.1: Dyed surface outcrop samples shown in transmitted plane light

Image 1: Grain-supported dolostone: grain structure

Image 2: Dolomitic packed biomicrite: depiction of carbonate content, calcite (A), dolomite (B)

Image 3: Dolomitic packed biomicrite: fossil content

Image 4: Dolomitic packed biomicrite: porphyroidal neomorphism: floating rhombs of dolomite and dedolomitization $(\mathrm{C})$

Image 3 shows the large array of Ordovician fauna preserved in these rocks as fossils. Image 4 shows a closer look at the porphyrotopic mosaic and floating dolomite rhombs. Many of the rhombs are well formed, planar, euhedral crystals indicating dolomitization of calcite. Other rhombs in the sample (i.e. as shown directly below section C) exhibit a dedolomitization process where calcite is replacing dolomite.

This second lithology correlates very well to what was observed in the Shell State Blair 2-24 well of Grand Traverse County by Hiatt (Hiatt, 1985). In this well, Hiatt had determined that the Collingwood was absent and leads us to believe that our outcrop samples were either obtained from the lower most Collingwood or the upper Trenton Formation correlative with that of Grand Traverse County. Additional sampling needs to be performed in order to determine whether or not the Collingwood is actually present in this area and the nature of its deposition. This may be aided by developing a robust chronostratigraphic framework with metabentonites visible in Chandler Falls. 


\subsection{Subsurface Samples}

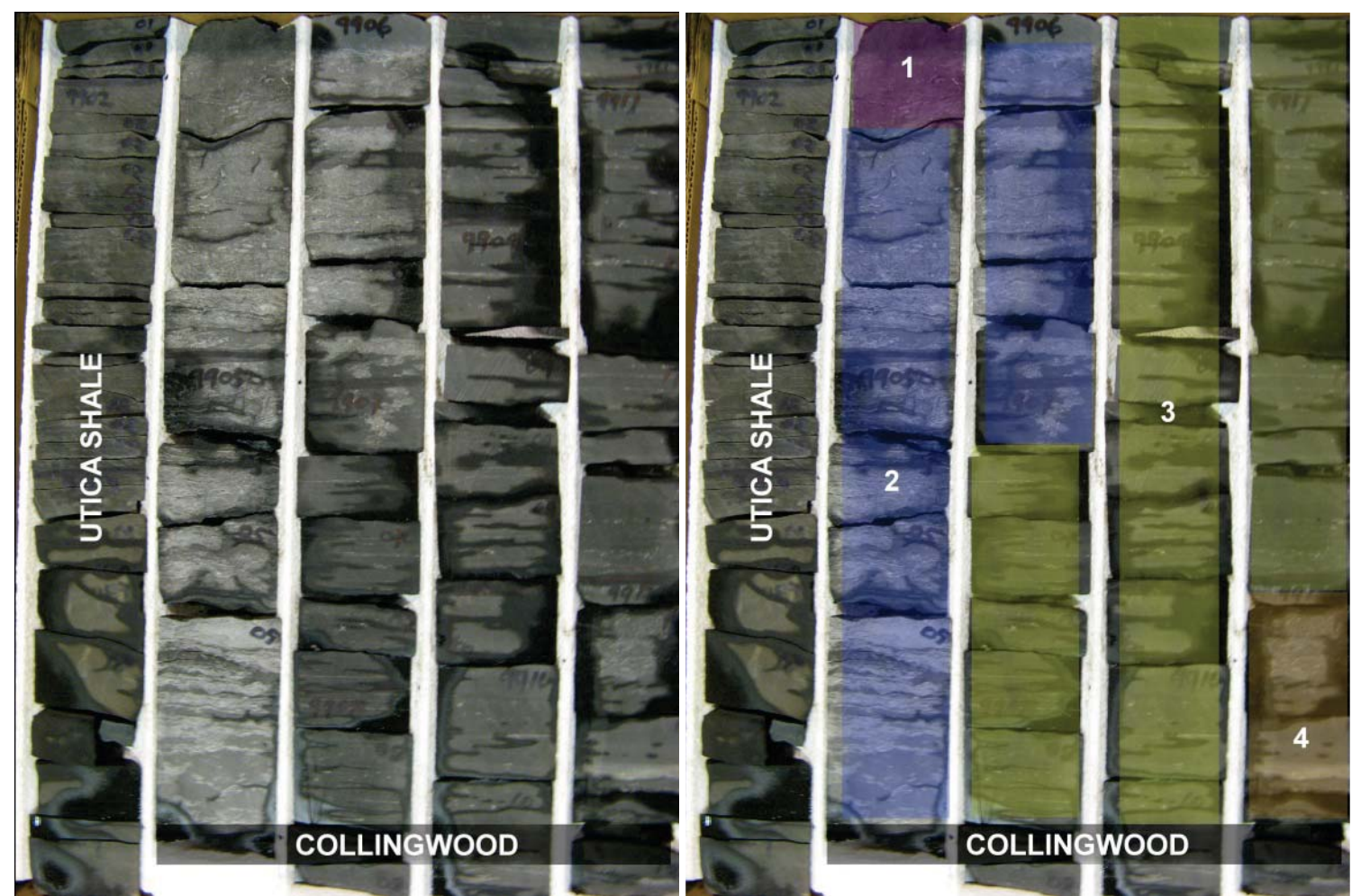

Figure 4.1: Well core section (left) with four distinct facies highlighted (right). Hunt Energy Corporation, Winterfield Deep Unit A1 (API: 21-035-33680-0100), Clare County, MI.

Subsurface samples were obtained from core retrieved from the JEM Petro Corporation Bruggers No. 3-7 (API: 21-113-34078-0000) in Missaukee County, MI. Selections were made from four distinct facies that were identified: (1) a marine hardground contact; (2) a shell debris layer; (3) a low energy finely laminated mud; and (4) a homogenized facies of mud and fossil debris. The drill core from the Hunt Energy Corporation Winterfield Deep Unit A-1 (API: 21-035-33680-0100) in Clare County, MI is shown as equivalent to the JEM Bruggers 3-7 in figure 4.1. Here, the same four unique facies are highlighted on a macroscopic scale.

The hardground contact facies is a phosphatic, finely crystalline, equigranular subhedral to euhedral dolostone with an idiotopic mosaic. Anhydrite was observed as a replacement mineral in the samples. Phosphatic nodules and phosphatised debris are dispersed in the dolomite matrix and at times have been replaced by dolomite. Pyrite in this facies is in a disseminated granular form with an approximate size of 20 microns. Dolomite matrix crystals are generally between 15-20 microns in size. Plate 4.2, image 1 illustrates the nature of the matrix and phosphatised debris in the contact facies. Section A shows a fracture filled with anhydrite. Plate 4.2, image 2 shows well developed dolomite rhombs replaced by anhydrite in section B and the fine grained idiotopic matrix dolomite in section C.

This facies has been observed in many cores by other authors in both Michigan and Canada. It is thought to be related to (1) a lithified marine sea floor and a long period of non deposition or (2) 

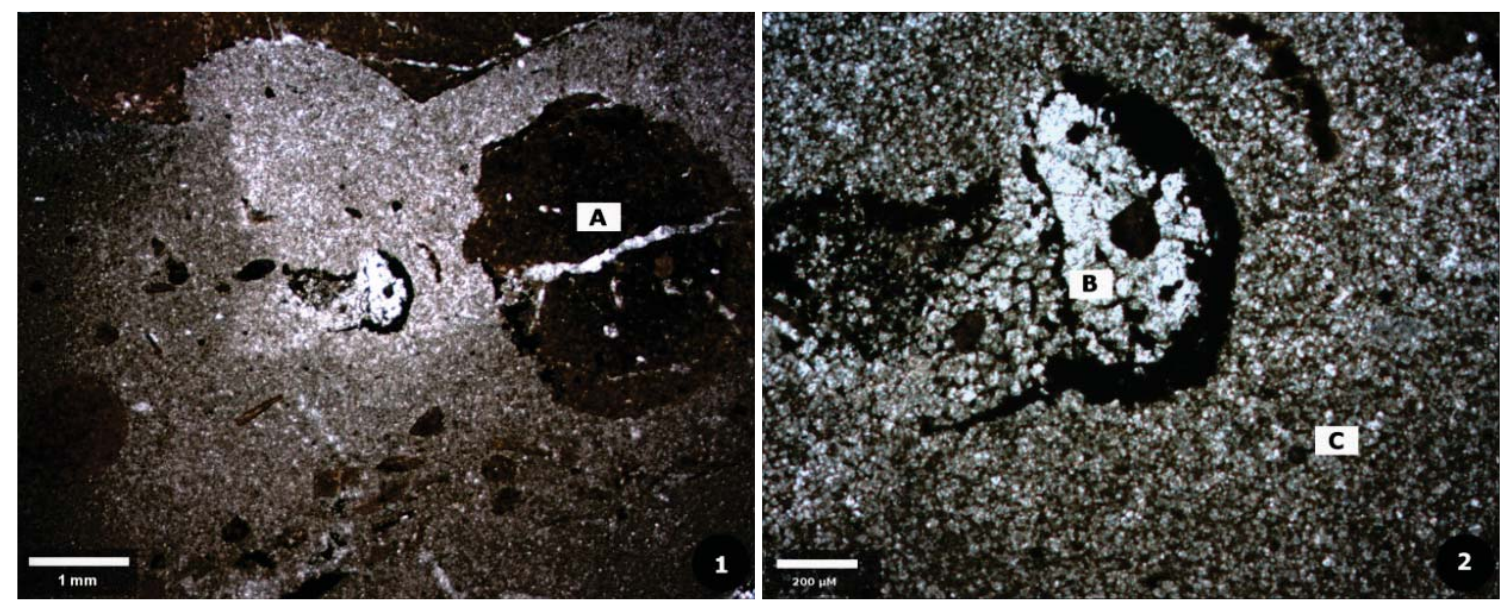

Plate 4.2: Hardground facies from JEM Petro Corporation, Bruggers No. 3-7 (API: 21-113-340780000), Missaukee County, MI at 9,660' core depth.

Image 1: Nodules and phosphatized debris: anhydrite replacement (A)

Image 2: Anhydrite replacement of dolomite (B) and dolomite matrix (C) also seen in the center of image 1

an erosional surface (Churcher, et al., 1991). It is interesting to note that Ordovician hardgrounds have been widely observed and studied in Ontario (Brett and Liddell, 1978). The facies is only present at the top of the unit for several inches and should not be confused with ferroan dolomitic caps of the Trenton.

The shell debris facies classifies as a packed biomicrite with many well preserved Ordovician fossils bound together in a dark, kerogen rich, microcrystalline calcite matrix. There is no particular orientation of the allochemical debris in this rock. Orientation (or hydraulic sorting) of shell debris may be used as an indicator to differentiate the source as either a tempestite or turbidite (Flugel, 2010, p. 593-600). After careful examination of crinoids in samples prepared from this facies and applying the criteria of Flugel (Flugel, 2010, p. 551-554) and others (Mehrtens, 1988), the limited observations suggest that the source of the fossil debris is more closely attributed to tempestites rather than turbidites. Crinoid fossil fragments observed in thin section occur in random orientations and do not appear to be hydraulically sorted. In addition, Bouma sequences were not observed in well core, rather, sharp bases of storm beds are present. Additional criteria noted for tempestite deposits are undulations of beds, hummocky cross stratification, and bioturbation (burrowing) present at the top of the storm beds. Undulations of shell lag and bioturbation were observed, however hummocky cross stratification was not. The lack of coarse grained storm beds suggests a distal tempestite as the source rather than a proximal (Flugel, 2010, p. 593-600). Additional work needs to be performed in order to verify these results in different regions of the Collingwood.

Many of the fossils exhibit microsparite recrystallization of micritic calcite (also noted by Hiatt) (Hiatt, 1985). Disseminated pyrite is also observed throughout the sections with diameters ranging from 20-30 microns. This facies is present throughout the core but is generally most concentrated near the top of the unit. Plate 3, image 1 shows the orientation and preservation of fossils that are dispersed in a, dark, muddy matrix. 


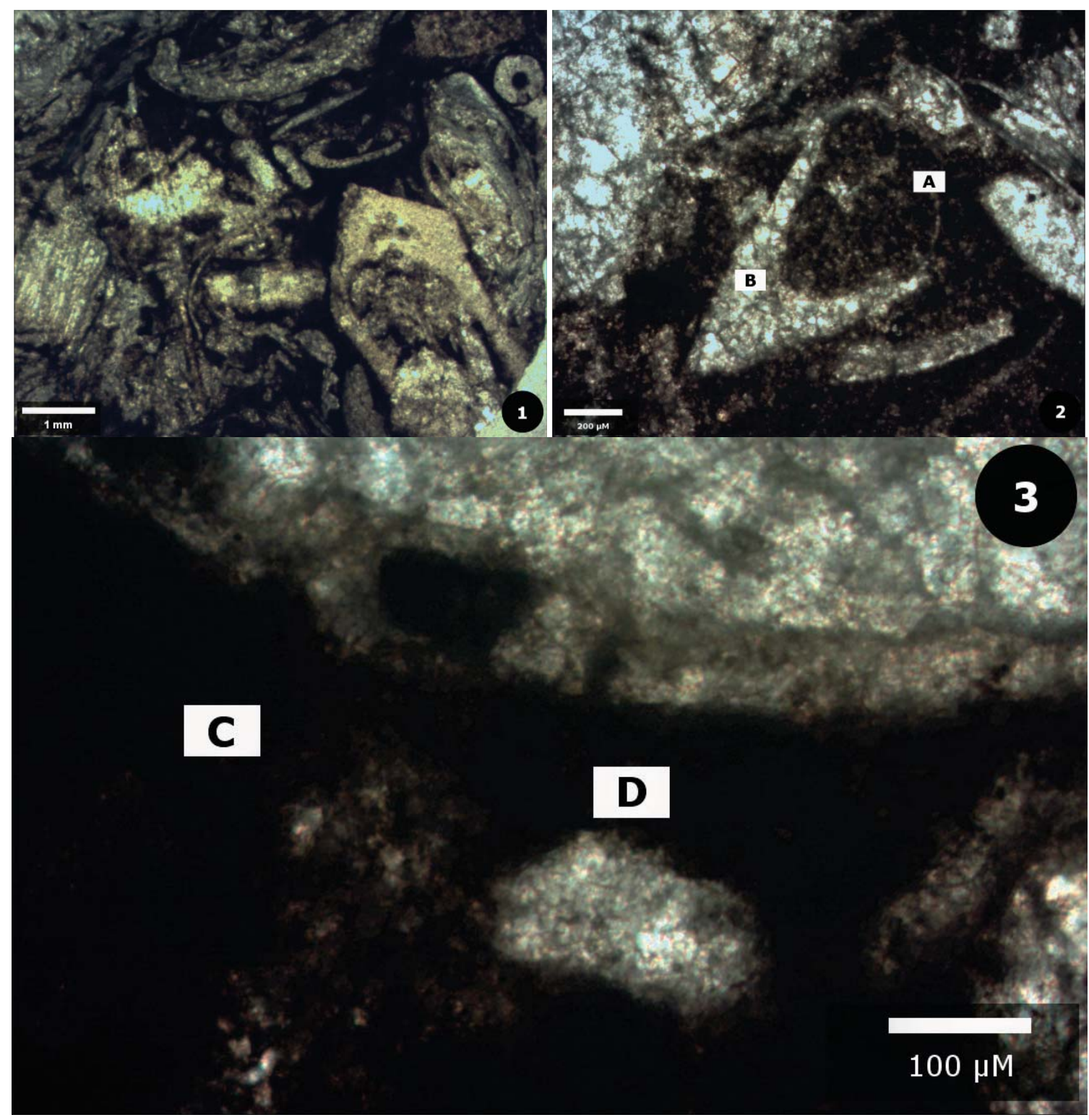

Plate 4.3: Packed biomicrite (fossil debris) facies from JEM Petro Corporation, Bruggers No. 3-7 (API: 21-113-34078-0000), Missaukee County, MI at 9,661' core depth.

Image 1: Fossiliferous debris and micrite matrix

Image 2: Micrite matrix crystal size (A) vs. fossil sparite recrystallization (B)

Image 3: Micrite matrix crystals in kerogen deficient $(\mathrm{C})$ and kerogen rich (D) regions

The second image demonstrates the difference in calcite crystal size between the kerogen rich mud (section A) and the spar crystallized fossils (section B). The third image also shows the micritic, but surprisingly angular, rhombohedral calcite crystals in both a kerogen rich (section C) and non kerogen rich (section D) environment in the matrix. The crystals appear to have a hypidotopic mosaic as noted by Flugel to be common in micritic rocks (Flugel, 2010, p. 73-99). 

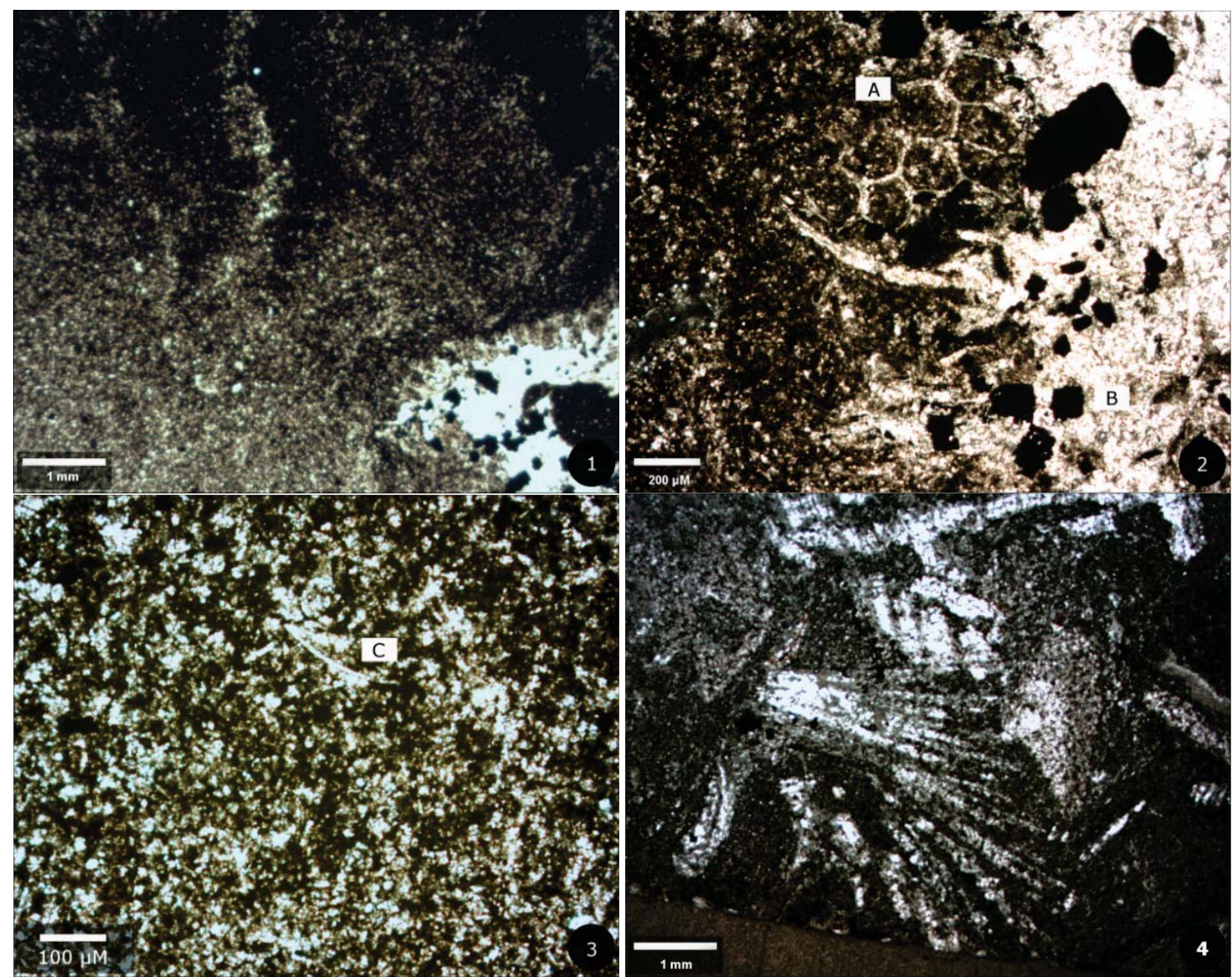

Plate 4.4: Laminated mud (siliceous micrite) and homogenized facies from JEM Petro Corporation, Bruggers No. 3-7 (API: 21-113-34078-0000), Missaukee County, MI at 9,666' and 6,671 ' core depth respectively.

Image 1: Siliceous micrite facies: Kerogen rich lithology

Image 2: Siliceous micrite facies: Bryozoan fossil (A) and pyrite crystals as opaque objects (B)

Image 3: Siliceous micrite facies: Small shelly fossil (C) in fine grained matrix

Image 4: Homogenized facies: Mixed fossil debris in micritic matrix

The laminated mud facies is the key distinguishing feature of the Collingwood Member in core. It is a finely laminated siliceous micrite that is highly organic in nature. It can be identified in core by its dark color, lack of fossil content, and the presence of thin, horizontal, low energy, lightly coloured, laminated calcite stringers. To note, the nature of the calcite stringers is unknown as they were not sampled in thin sections, however, it is theorized that they are likely related to fossil debris as seen elsewhere in the core.

The rich kerogen content makes it difficult to distinguish many features optically under transmitted plane light due to opacity (see plate 4.4, image 1). It is easy to see how one can misidentify the Collingwood as a shale in hand samples due to its dark fissile nature. However, the Collingwood carbonate content is identifiable in XRD analysis and partially in thin section. The silica content of the rock is extremely difficult to distinguish from calcite in thin section optically, also noted by Hiatt 
due to poor birefringence in small crystals (Hiatt, 1985). Fossil content is very sparse in this facies with few observations of byrozoans and very small shell fragments (plate 4.4, image 2, section A and plate 4.4 , image 3 , section $\mathrm{C}$ ).

Disseminated microgranular pyrite is also visible in this section with diameters of approximately 15-20 microns. Some large, well developed, euhedral cubic crystals of pyrite are observed with sizes of 100200 microns in vugs (plate 4.4, image 2, section B). The formation of the pyrite crystals is likely authigenic indicating formation under reducing conditions, within close proximity of rich organic material (Flugel, 2010). Additional work might be performed to determine if framboidal pyrite is present in the Collingwood to indicate a carbonate shelf or deep-marine environment (Flugel, 2010, p. 646-647).

The average size of carbonate matrix crystals ranges between 1 and $20 \mu \mathrm{M}$ along the longest crystal diameter. According to Folk (Folk, 1959) a crystal size limit of $4 \mu \mathrm{M}$ is required for classification as a micrite, however Flugel points out that upper crystal size limits vary among authors ranging from 10 $\mu \mathrm{M}$ to $30 \mu \mathrm{M}$ (Flugel, 2010, p. 75) and we will use an upper limit of $30 \mu \mathrm{M}$ for micrite in this paper. The micrite crystals present as anhedral to subhedral in shape (plate 4.4, image 3). To note, no large clusters of kerogen in pores were identifiable in thin section with the majority of organic material well dispersed in the matrix. This facies is present throughout the core and compromises the majority of deposition. It consequently also contains the regions of highest TOC and porosity both.

There is also the question as to whether or not the fine grained micrite present in the Collingwood was diagenetic in nature. Flugel discusses the process of grain diminution, or degrading neomorphism, a process by which larger crystals may be replaced by smaller ones during early and burial diagenesis (Flugel, 2010, p. 73-99). However, if this were the case, the larger calcite crystals $(>20 \mu \mathrm{M})$ found in fossils of the shell debris facies likely would not exist. There seems to be sufficient evidence to identify the laminated mud facies as low energy deposit.

A fourth and final facies exists as a homogenized variant of laminated mud and shelly debris (plate 4.4, image 4). This facies is a bio-micrite that contains some kerogen and silica content in its matrix. It is present throughout the core, but appears primarily near the bottom and Trenton transition. It can be distinguished from the Trenton by its kerogen content and non-nodular texture.

\subsubsection{Insoluble Residue Analysis}

A portion of the laminated mud (siliceous micrite) facies that was treated to remove carbonate content and kerogen resulted in a mixture of dark, kerogen rich, clay platelets mixed with finely crystalline (kerogen deficient) silicic grains. Small crystals of well formed, tabular anhydrite were also observed under reflected light. 


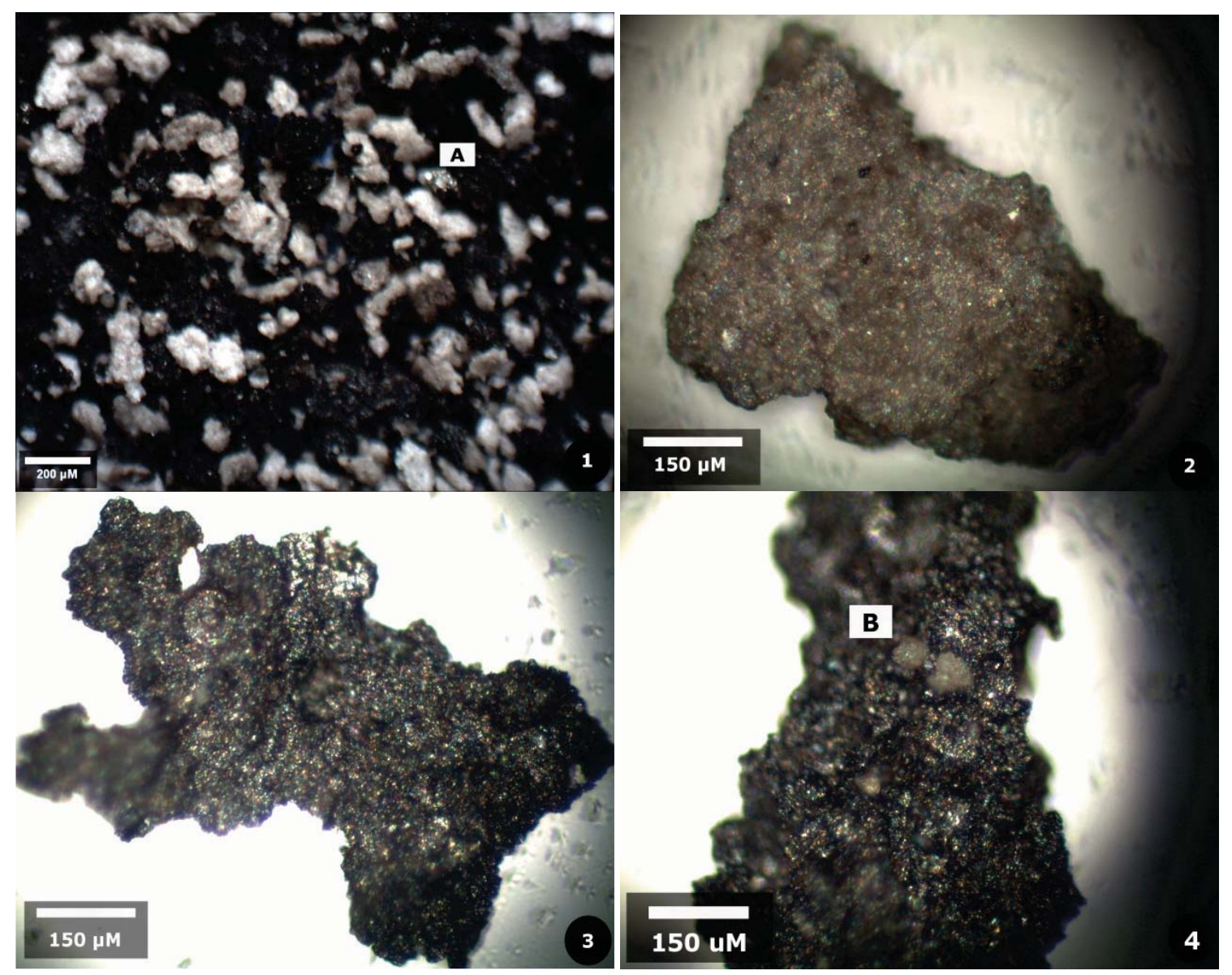

Plate 4.5: Insoluble residue from JEM Petro Corporation, Bruggers No. 3-7 (API: 21-113-340780000), Missaukee County, MI at 9,663' core depth (siliceous micrite facies) under reflected light. Image 1: Silica and clay clasts: pyrite coating silica clast (A)

Image 2: Silica clast

Image 3: Clay platelet

Image 4: Silica clasts embedded in clay platelet (B)

The source of the silica and clay components in the residual sample is unknown. The microcrystalline silica contains very little to a complete absence of pyrite and kerogen. The nature of the silica as can be seen from both transmitted and reflected light petrophotography, is simply micro to cryptocrystalline quartz that is anhedral to subhedral in crystal shape. It has not been seen in any cases as a fibrous (chalcedony) silica. It does however form particular shaped grains. The grains are not flat or plated, like the clay component and can be seen in both SEM images and in plate 4.5, images 1 and 2 .

The source of silica in the Collingwood has not yet been determined. Whether it was part of a replacement process, deposited as detrital quartz grains, or otherwise is unknown and it is beyond the scope of this project to determine the diagenetic process responsible if applicable. One possible terrigenous source is a metaquartize outlier as proposed by Rancourt for samples he studied on Manitoulin Island (Rancourt, 2009). Sharma et al also observed silica components in Collingwood samples from Ontario and Michigan both. They suggest replacement of calcite cement by chalcedony 
and observed fine-grained quartz sand in the matrix (Sharma et al., 2003). Neither of these forms of silica were found in samples prepared in this study.

The clay component of the insoluble residue is in the form of platy clasts. On a macroscopic level they appear to be blade-like and very thin, reflecting the typical appearance of phyllosilicate structures. The clay component can be seen as the dark black clasts in plate 4.5, image 1, image 3 and in image 4. The source of the clay component is not known, however the clay is very rich in organic material and contains authigenic pyrite indicating deposition in a reducing environment. The process by which the kerogen is incorporated into the clay structure is unknown, however possibly may be attributed to syndeposition. Silica clasts embedded in the clay can be seen in image 4, section B. 


\section{Mineralogy}

\section{$5.1 \quad$ Outcrop Samples}

The grain-supported dolostone lithology was found to be primarily dolomite by $\mathrm{x}$-ray diffraction results with an unmeasurable amount of calcite present that was only visually observed in thin section via staining. The dolomitic bio-micrite lithology produced results that ranged between 40-50\% dolomite and 50-60\% calcite with a low (2-4\%) quartz component. The high dolomite fraction may be indicative of a regional dolomite trend, as observed in other parts of the Michigan Basin (Catacosinos et al., 1991; Wilson et al., 2001). The two Trenton Limestone samples retrieved from Groos Quarry ranged from primarily calcite to partly dolomite with some quartz content. A summary of computed quantitative I/C results are in shown in table 1.

Table 1: Quantitative I/IC mineralogy for outcrop samples in the Collingwood and Trenton.

\begin{tabular}{llllll}
\hline Sample & Formation & Calcite \% & Dol. \% & $\mathrm{SiO}_{2} \%$ & Lithology \\
\hline $\mathbf{0 1}$ & Collingwood & & 100 & & Doloarenite \\
$\mathbf{0 2}$ & Collingwood & 50.8 & 45.5 & 3.7 & Dolostone \\
$\mathbf{0 3}$ & Collingwood & 55 & 43.1 & 1.9 & Dolostone \\
$\mathbf{0 4}$ & Trenton & 100 & & & Limestone \\
$\mathbf{0 5}$ & Trenton & 76.3 & 21.5 & 2.2 & Dolomitic Limestone \\
\hline
\end{tabular}

\subsection{Subsurface Samples}

The samples used were extracted from the JEM Bruggers 3-7 well core in the following formations and quantities: Utica Shale (1), Collingwood Member (11), and Trenton Formation (1). The Utica shale was found to contain primarily silica and clay content with a small carbonate fraction present. The Collingwood mineral composition varies with high dolomite content near the Utica contact in the hardground facies quickly grading to high calcite content (as the carbonate fraction) in the majority of the core with silica following its own independent trend. Near the Trenton contact, silica content grades out and calcite dominates. The Trenton formation was found to be primarily carbonate (calcite). These results can be interpreted as shown in table 2, or more easily visualized in accompanying figure 5.1 .

In the hardground contact dolomite, anhydrite, and phosphatic minerals were observed. After carbonate content was removed from a siliceous micrite sample, silica and clays were observed in the form of iron chlorite, muscovite and illite. The clay minerals were distinguished in XRD data by peak pattern matching. It was found that the micas (muscovite and illite) shared very similar peaks and only one was used in order to compute I/C results (figure 5.2). To note, Hiatt also observed these same clay minerals in samples from her study (Hiatt, 1985). These results were normalized to show an accurate contribution of silica and clay after dissolution. 
Table 2: Computed I/I $\mathrm{I}_{\mathrm{C}}$ mineralogy for subsurface samples from JEM Petro Corporation, Bruggers No. 3-7 (API: 21-113-34078-0000), Missaukee County, MI. Core depth shown.

\begin{tabular}{llllll}
\hline Depth & Formation & Carbonate \% & Silica \% & Clay \% & Facies \\
\hline $\mathbf{9 , 6 5 6}$ & Utica Shale & 5.6 & 40 & 54.4 & Utica Shale \\
$\mathbf{9 , 6 6 0}$ & Collingwood & 91.1 & 5.4 & & Hardground \\
$\mathbf{9 , 6 6 1}$ & Collingwood & 98.4 & 1.6 & & Shell Debris (dolomitic) \\
$\mathbf{9 , 6 6 2}$ & Collingwood & 100 & & & Shell Debris \\
$\mathbf{9 , 6 6 3}$ & Collingwood & 90 & 5.5 & 4.5 & Laminated mud \\
$\mathbf{9 , 6 6 6}$ & Collingwood & 89 & 11 & & Laminated mud \\
$\mathbf{9 , 6 6 9}$ & Collingwood & 79 & 21 & & Laminated mud \\
$\mathbf{9 , 6 7 1}$ & Collingwood & 94.5 & 5.5 & & Homogenized \\
$\mathbf{9 , 6 7 4}$ & Collingwood & 87 & 13 & & Homogenized \\
$\mathbf{9 , 6 7 6}$ & Collingwood & 87 & 13 & & Laminated mud \\
$\mathbf{9 , 6 8 0}$ & Collingwood & 89 & 11 & & Laminated mud \\
$\mathbf{9 , 6 8 6}$ & Collingwood & 89 & 11 & & Homogenized \\
$\mathbf{9 , 6 9 0}$ & Trenton & 96.5 & 3.5 & & Trenton Limestone \\
\hline
\end{tabular}

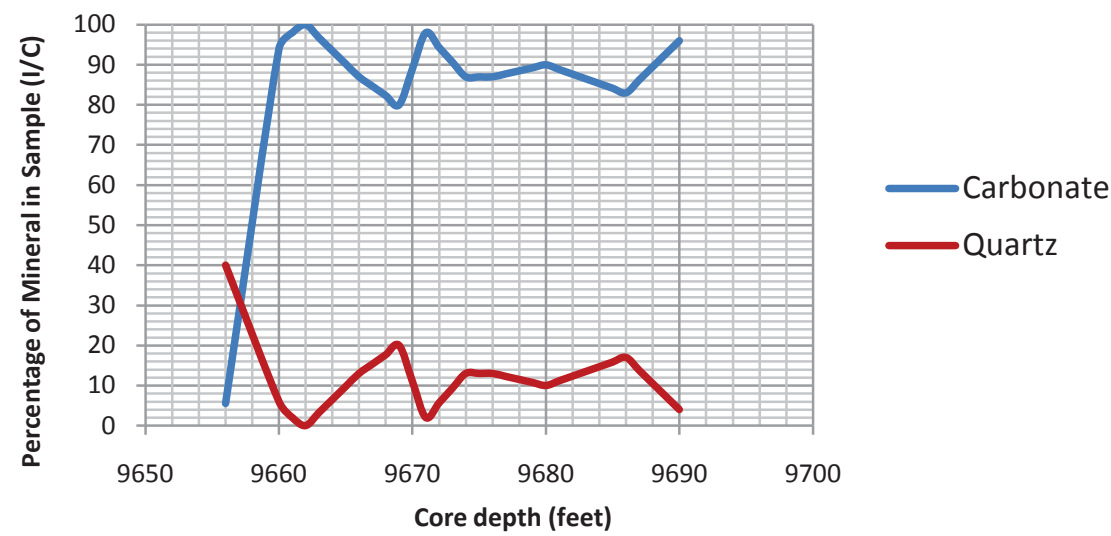

Figure 5.1: Carbonate and quartz contributions from JEM Petro Corp. Bruggers No. 3-7 (API: 21113-34078-0000), Missaukee County, MI.

It was not possible to account for the amount of kerogen due to its insoluble and inseparable nature, therefore its contribution to the bulk rock volume is unknown. Calculations however were performed based on wireline and pyrolysis data in order to get an estimate of bulk kerogen volume. The following equation was used, as presented by ResTech (Luffel and Lorenzen, 2009).

$$
K_{v}=\left[\frac{T O C-S 1 * C_{S 1}}{C_{K}}\right] * \frac{\rho_{b}}{\rho_{K}}
$$




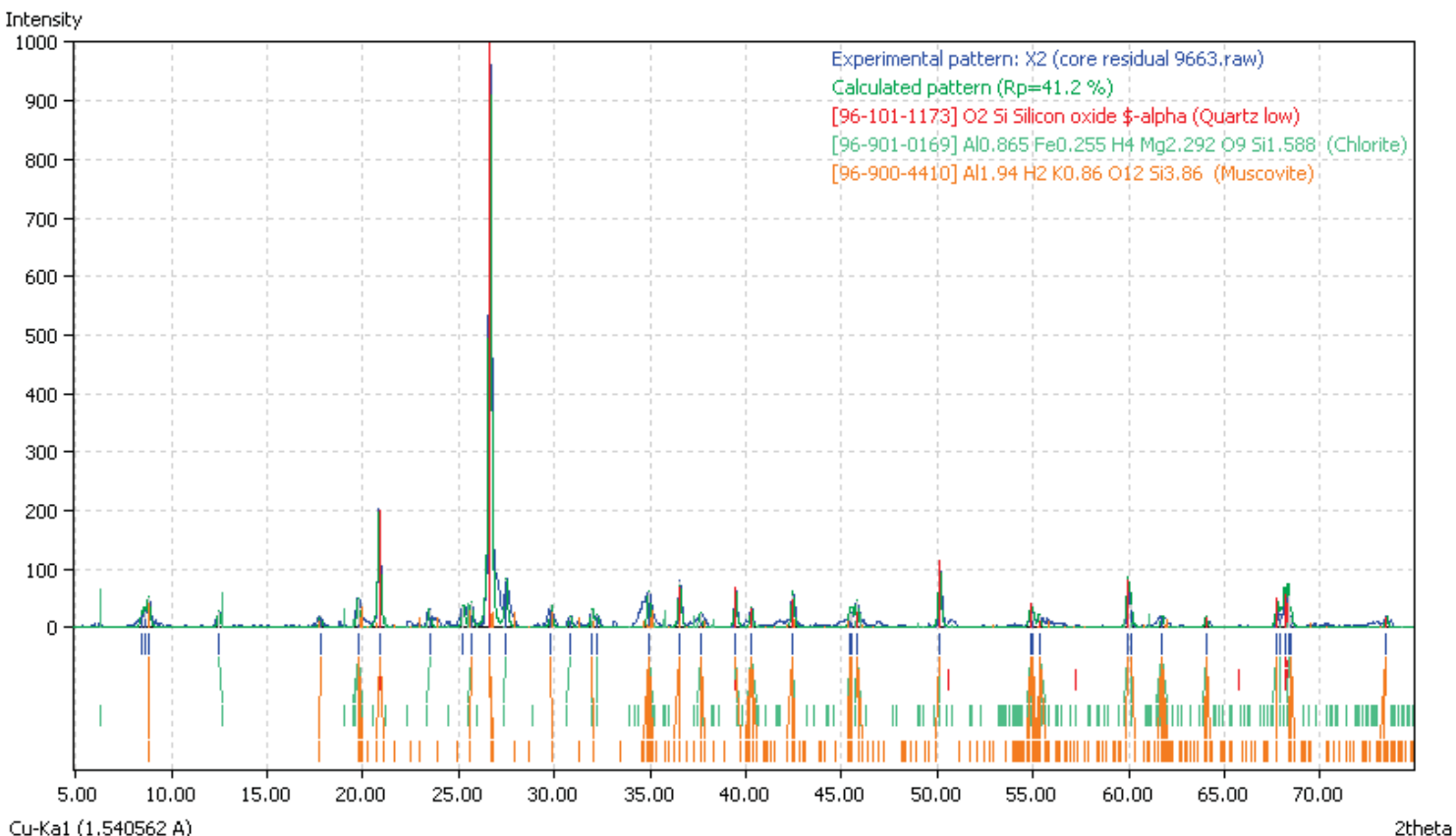

Figure 5.2: Pattern matching of insoluble residue using Crystal Impact's Match! Software (XRD peaks and superimposed patterns shown). Sample from JEM Petro Corporation, Bruggers No. 3-7 (API: 21-113-34078-0000), Missaukee County, MI, 9,663' core depth.

Using this calculation (with values of $\mathrm{TOC}=3.17, \mathrm{~S} 1=0.61, \rho_{\mathrm{b}}=2.612$ from $\log , \mathrm{\rho}_{\mathrm{K}}=1.1, \mathrm{C}_{\mathrm{S} 1}=0.87$ and $\mathrm{C}_{\mathrm{k}}=0.77$, the latter two assumed for thermal maturity) we find that at the depth of 9,663' in the JEM Bruggers 3-7 well, kerogen volume is computed to be $7.3 \%$. It should be noted that clays were not calculated where not shown and quantitative I/C assumes only carbonate and silica fractions (table 2 ). Correction for kerogen and clay content should reduce total contributions of the carbonate and silica phases to bulk rock volume.

It is important to note that the overlying Utica Shale is mineralogically a traditional shale in the sense that it consist of primarily silica and clay with very little carbonate content. The Collingwood conversely classifies as a carbonate, having values of roughly between $80-90 \%$ carbonate content with very small siliceous and argillaceous components.

The dolomite content of the Collingwood is variable in the Michigan Basin. Well cores examined by Hiatt (figure 5.3) indicated higher dolomite content than the JEM Bruggers 3-7 analysed in this study from the deep basin (Hiatt, 1985). A summary of averaged dolomite percentages is shown in table 3. These average values were computed either by digitizing scanned images and averaging integrated values with Neuralog software or with numerical data. To note hydrothermal dolomitization processes that have been observed in the Michigan Basin could occur on a local basis, especially along observed fractures or fault systems (Prouty, 1988; Catacosinis et al., 1991). In addition, Hiatt considered the Wagner \#2 core to contain stoichiometric dolomite and suggested that it was regional in nature and indicative of mineralizing solutions. 
Table 3: Approximate dolomite percentages in the Collingwood and Trenton (Michigan Basin) from XRD analysis $\left(\mathrm{I} / \mathrm{I}_{\mathrm{C}}\right)$.

\begin{tabular}{lllll}
\hline Source & Well & County & Formation & Avg. Dol \% \\
\hline Hiatt & St. Blair \#2-24 & Grand Traverse & Trenton & 25 \\
Hiatt & St. Albert \#1-10 & Montmorency & Collingwood & 20 \\
Hiatt & Taratua \#1-13 & Presque Isle & Collingwood & 20 \\
Hiatt & St. Allis \#2-30 & Presque Isle & Collingwood & 20 \\
Hiatt & Wagner \#2 & Delta & Collingwood & 40 \\
Banas & Bruggers \#3-7 & Missaukee & Collingwood & $<5$ \\
Banas & Outcrop & Delta & Unknown & 45 \\
\hline
\end{tabular}

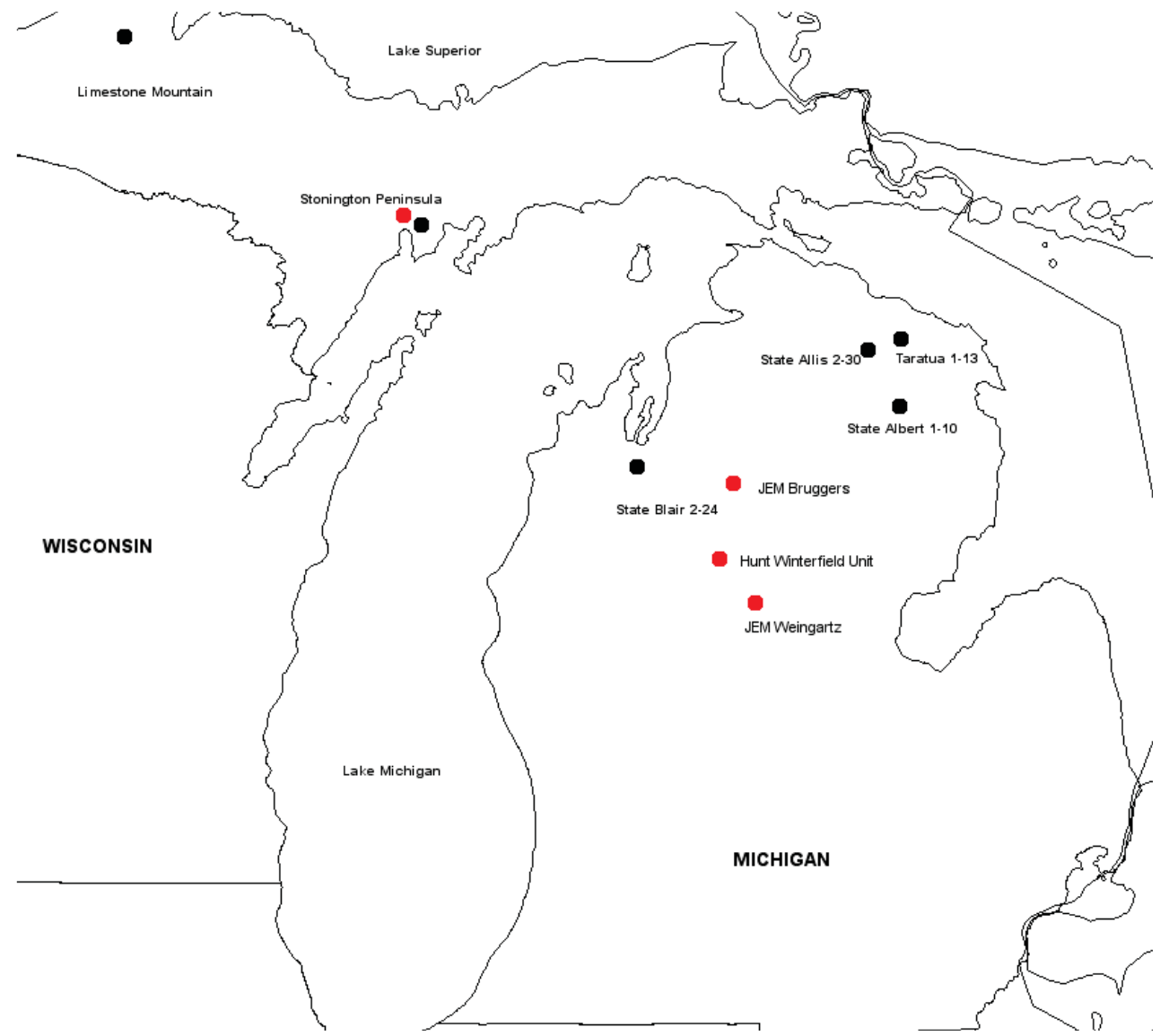

Figure 5.3: Diagram depicting outcrop and well bore locations with available Collingwood samples in the Michigan Basin. Wells used in Hiatt's study are shown in black. Wells used in this study are shown in red. Wagner \#2 is unlabeled but shown in Delta County in the Upper Peninsula of Michigan. 


\section{SEM Imaging}

SEM imaging and X-ray mapping was performed to gain both a quantitative and qualitative understanding of the porosity structure and physiological relationship of minerals in the Collingwood. Samples from the JEM Bruggers 3-7 core at depths of 9,666' and 9,669', both siliceous micrites, were imaged and mapped respectively.

\subsection{Secondary Electron Imaging}

Secondary electron imaging provides additional information about the nature of silica and clay content embedded in the microcrystalline carbonate matrix of the Collingwood. Results indicate that the vast majority of porosity in the rock is directly associated with the carbonate matrix. These images coupled with reflected light images from samples with carbonate content removed show the nature of silica and clay components of the Collingwood and their lack of porosity.

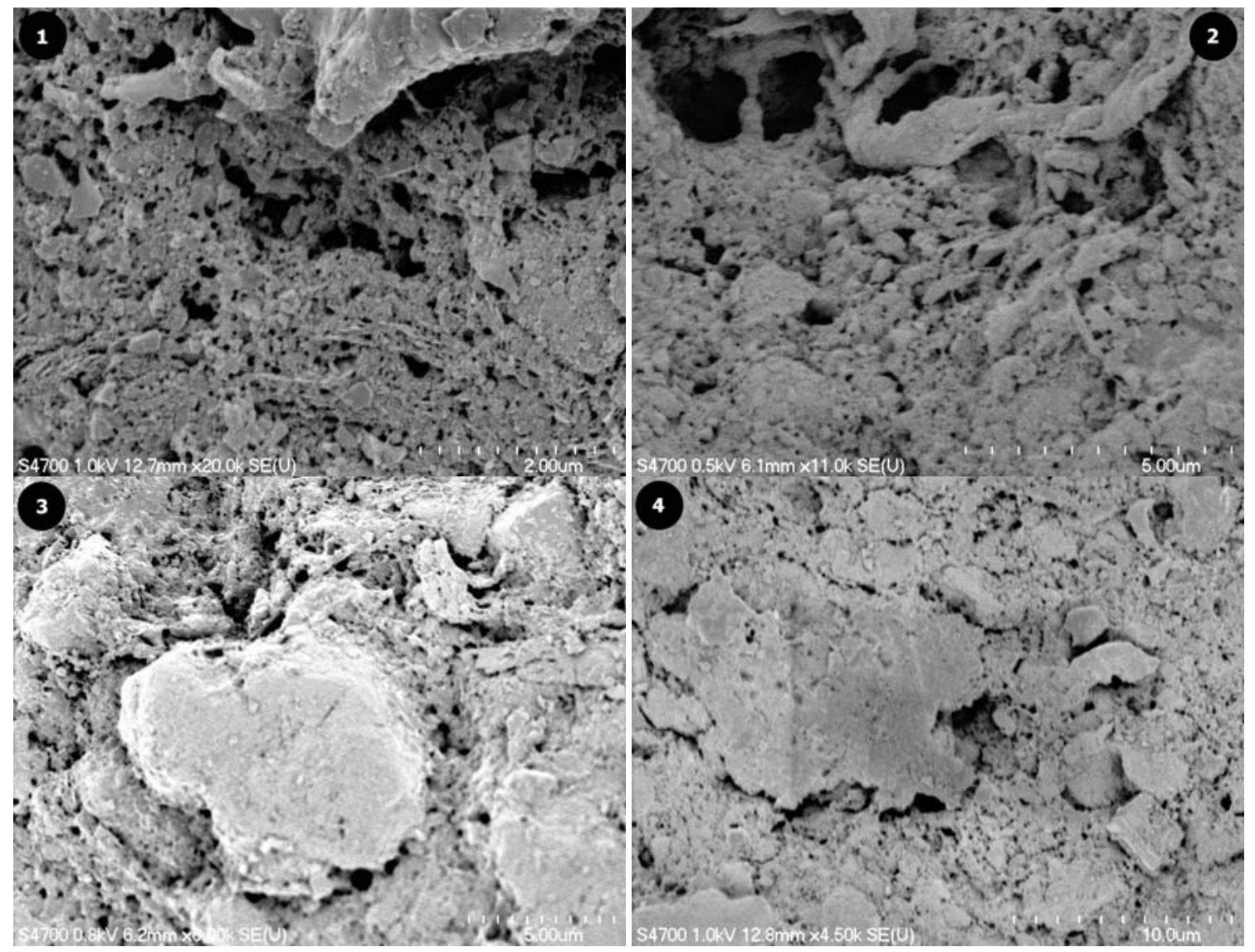

Plate 6.1: Secondary Electron Images from JEM Petro Corporation, Bruggers No. 3-7 (API: 21113-34078-0000), Missaukee County, MI, 9,669' core depth (region of highest measured porosity). Image 1: 20,000 times magnification of micrite matrix and porosity structure Image 2: 11,000 times magnification of micrite matrix and porosity structure Image 3: 6,000 times magnification of embedded clast in matrix

Image 4: 4,500 times magnification of embedded clasts in matrix 
The Collingwood matrix (plate 6.1) shows small plates of calcite and allochemical debris bound together to form the porosity structure of the rock. ImageJ threshold porosity of these images are as follows: (1) $21 \%$ at 20,000 times, (2) $19 \%$ at 11,000 times, (3) $6 \%$ at 6,000 times, (4) $7 \%$ at 4,500 times magnification. To note, images at 500 times magnification exhibit roughly $2 \%$ porosity.

The nature and size of the porosity structure in the microcrystalline calcite matrix of the Collingwood is best classified as microporosity (Flugel, 2010, p. 73-99). The classification of microporosity given by Flugel is a 5-10 $\mu \mathrm{M}$ scale micropore system in micritic limestones. He indicates that it includes "both primary and solution-enhanced intercrystalline pores, as well as micromolds, microvugs and microchannels...and is developed in many subsurface micritic limestones" (Flugel, 2010, p. 74). As has been observed from secondary electron SEM imaging, this is a very fitting description of the microfabric of the Collingwood matrix. Pores measured in plate 6.1, image 1 range from less than 1 $\mu \mathrm{M}$ in size to a maximum of 6-7 $\mu \mathrm{M}$. The large pores in the upper left hand corner of plate 6.1, image 2 are 15-17 $\mu \mathrm{M}$ along their longest diameter.

As was seen in reflected light petrographic images, clasts of clay and silica were produced as insoluble residue after carbonate content was dissolved. These same types of clasts similar in both shape and size are visible in secondary electron images. It is possible to see in plate 6.1, images 3 and 4 , the nature and size of these embedded objects. To note, the large detrital deposit in the center of plate 6.1, image 4 is $150 \mu \mathrm{M}$ in diameter, approximately the same magnitude in size as the siliceous residue in plate 4.5 , image 1 .

It is also worthy to discuss the absence of limestone generating phytoplankton, coccolith or other structures in SEM images. This indicates a complete dissolution of calcareous nano-organisms and a recrystallization of calcite during diagenesis (Flugel, 2010, p. 73-99).

\subsection{X-Ray Mapping}

X-ray mapping was performed in order to gain a better understanding of the spatial relationship of mineral phases in the Collingwood. Two specific sections were targeted (figure 6.1) and mapped yielding the following results.

The first region mapped (figure 6.1, left) corresponds with a silica rich section and likely associated with a nodule of microcrystalline silica previously observed in secondary electron and microscopy images. The results (figure 6.2) show that there is a very high concentration of silicon and oxygen in the center of the image with deficiencies in all other elements indicating a form of silica. Supplemental EDS point analysis in this region (figure 6.1, left, pt. 1) confirmed these results.

EDS point analysis was also performed on the carbonate content in this sample (figure 6.1, left, pt. 2, pt. 4) and results show very little to no magnesium and high intensities of calcium, carbon, oxygen, aluminium, potassium and silicon. The latter elements are likely contributions from nearby clays. 


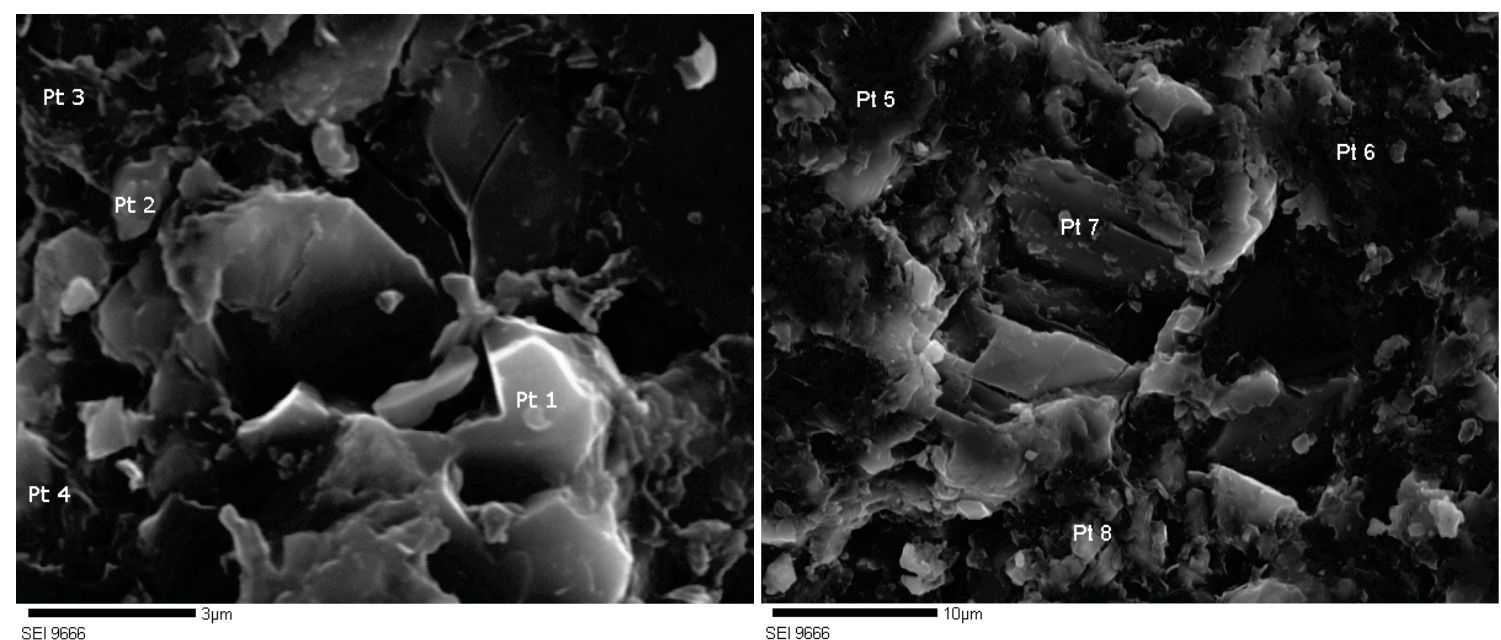

Figure 6.1: X-Ray mapping regions 1 (left) and 2 (right). Points where EDS analysis performed are labeled. Images taken from a prepared thin section, JEM Petro Corporation, Bruggers No. 3-7 (API: 21-113-34078-0000), Missaukee County, MI, 9,666' core depth.
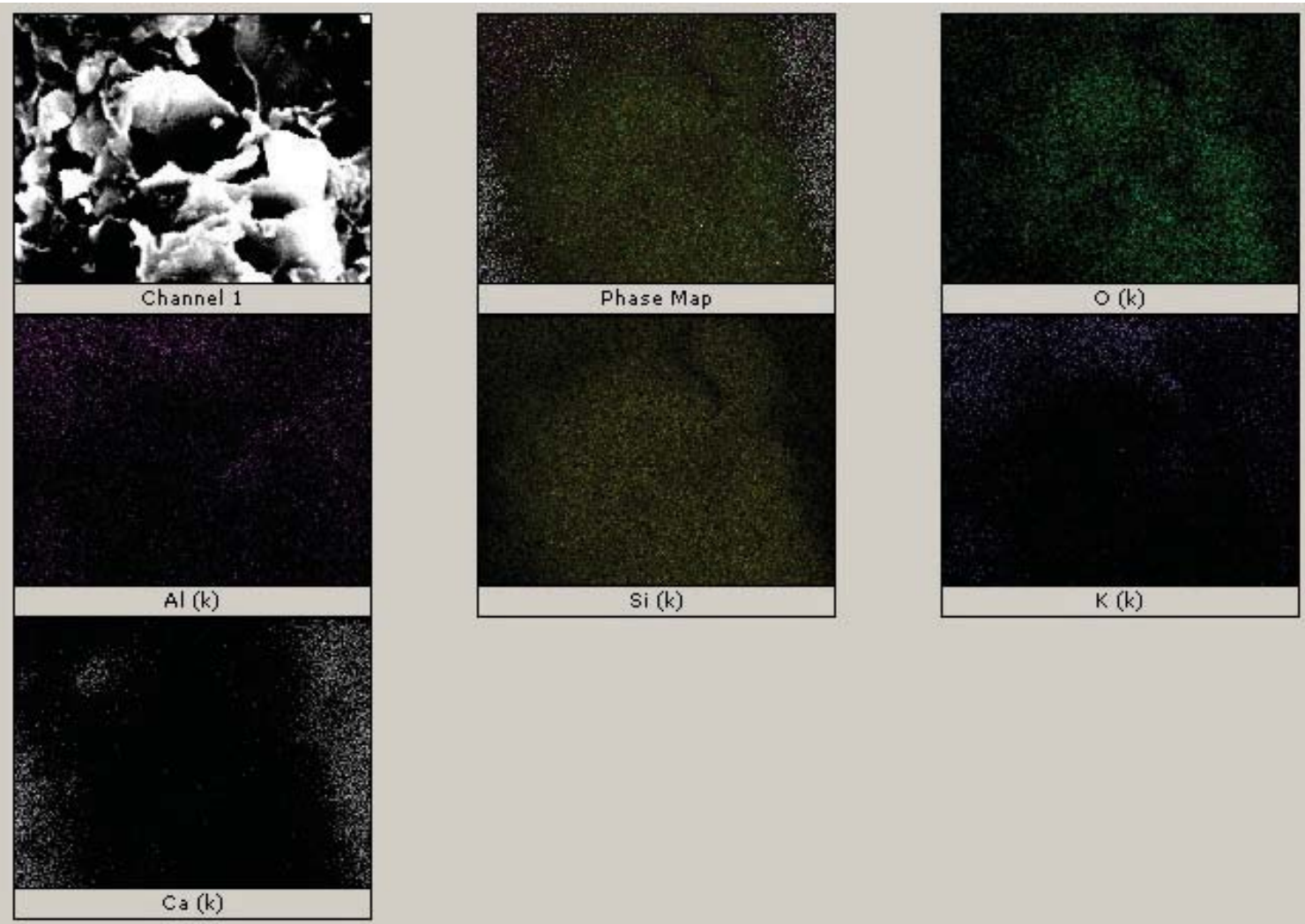

Figure 6.2: Elemental yields x-ray map region 1, JEM Petro Corporation, Bruggers No. 3-7 (API: 21-113-34078-0000), Missaukee County, MI, 9,666' core depth. 

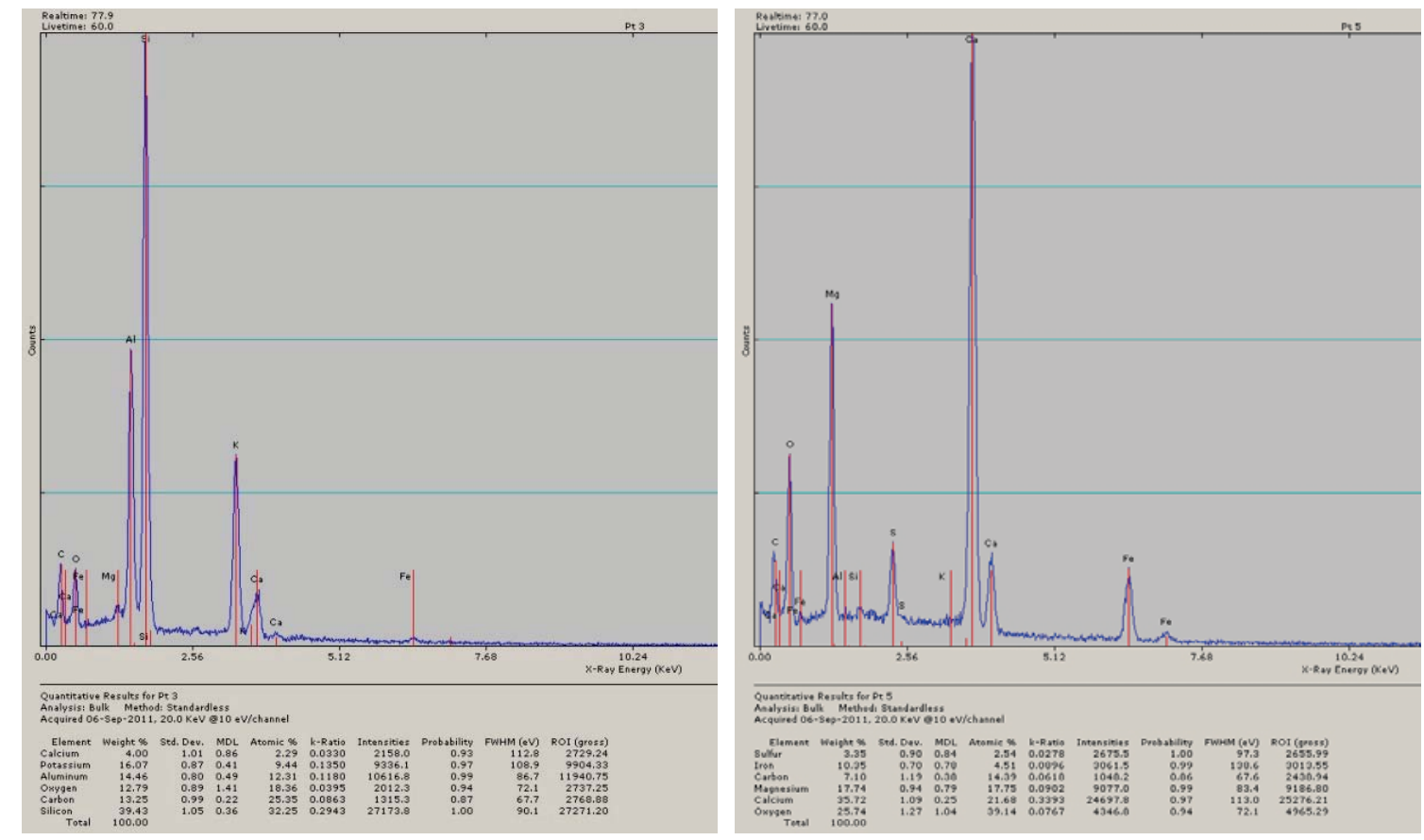

Figure 6.3: Point 3 EDS spectrum (left), Point 5 EDS spectrum (right), JEM Petro Corporation, Bruggers No. 3-7 (API: 21-113-34078-0000), Missaukee County, MI, 9,666' core depth.
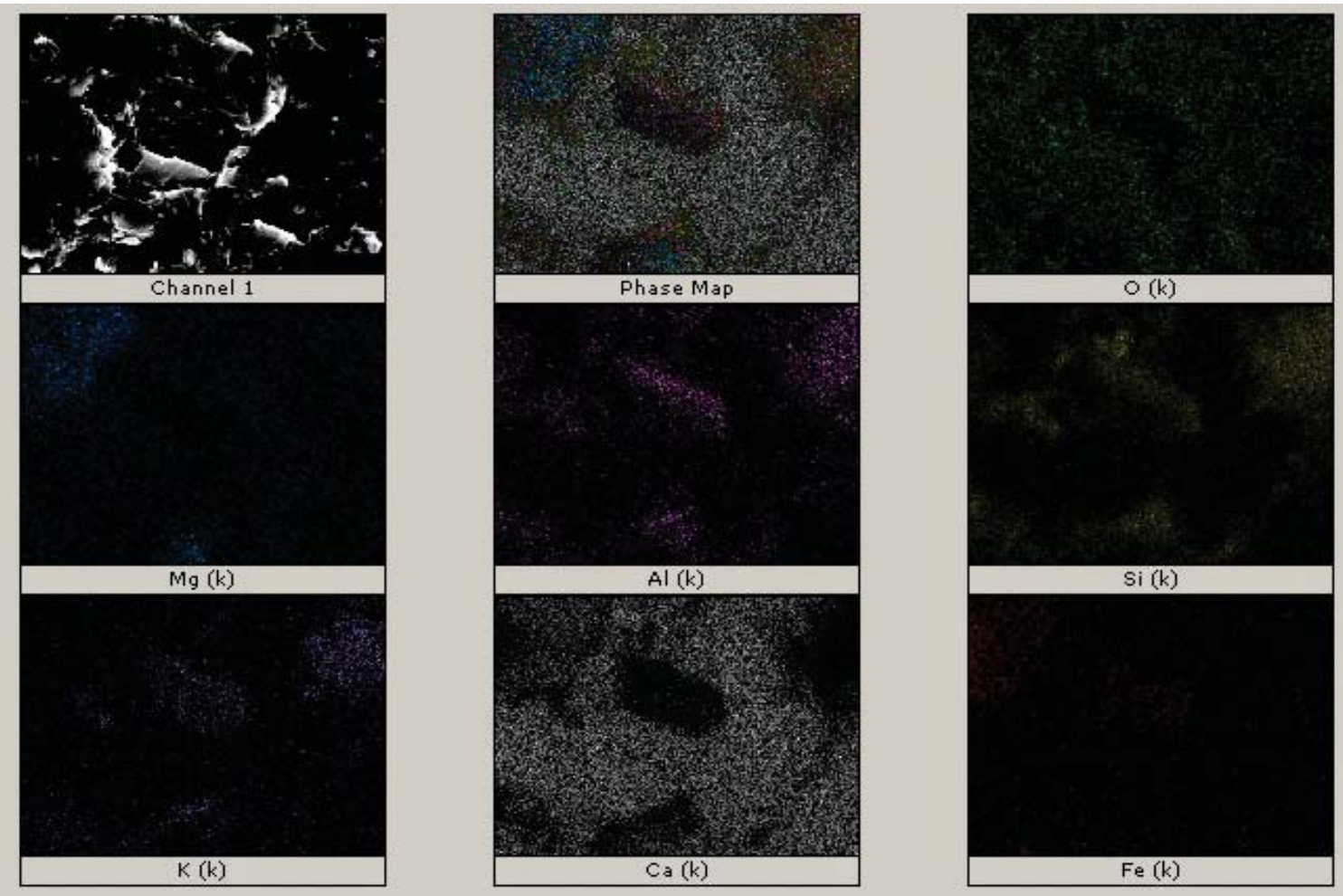

Figure 6.4: Elemental yields x-ray map region 2, JEM Petro Corporation, Bruggers No. 3-7 (API: 21-113-34078-0000), Missaukee County, MI, 9,666' core depth. 
The clay content found (pt. 3) was also analysed with EDS point analysis and found to be mica group minerals with elemental contributions of aluminium, silicon, and potassium and very little iron present (figure 6.3, left).

The second region mapped (figure 6.1, right) clearly defines several spatial areas of previously identified minerals from x-ray diffraction such as: iron chlorite, illite/muscovite, dolomite, pyrite, and calcite (figure 6.4). The upper left of the mapped region (figure 6.1, right, pt 5) shows elevated magnesium, oxygen, calcium, and iron content. An EDS point analysis of this area showed a large sulphur peak indicating a magnesium rich calcite or ferroan dolomite and contribution to the spectra from pyrite (figure 6.3, right).

The central portion of the image (pt 7), directly above the rhombohedral calcite crystal shows contributions from aluminium, silicon, potassium, and iron with a deficiency in calcium. It is likely that there is both iron chlorite and mica group minerals in this region consistent with these elements. An EDS point analysis was done in this region showing carbon, oxygen, aluminium, silicon, potassium, calcium and iron peaks with no sulphur present. The high concentration of calcium in this region (26.73\% I/C by weight) is indicative of the finely crystalline and dispersed nature of the microcrystalline calcite in the Collingwood.

The upper right portion of the image (pt 6) has high concentrations of silicon, oxygen, aluminium, and potassium. It is also deficient in calcium and does not have any iron contribution. An EDS point analysis shows carbon, oxygen, aluminium, silicon, potassium, and very small iron peaks with no sulphur. Based on the observed elements it is likely that this region is concentrated primarily with micas and not iron chlorite. Likewise, the region in the bottom center of the image (pt 8) shows a deficiency in calcium and a slight elevation in potassium, aluminium, and silicon. This area is likely also composed of mica group minerals. 


\section{Core Analysis}

Core data was supplied from MGRRE for three wells in the deep basin. Some sample points were also available in this data suite for the overlying Utica Shale and underlying Trenton Formation for comparison to the Collingwood. The data includes effective porosity (or hydraulically communicative porosity), permeability, and TOC wt\% via conventional whole core analysis measured by Core Labs.

\subsection{Porosity}

Core measurements show the Collingwood to have between 2-4\% porosity in its best regions. Comparison of these measured porosities to threshold porosities previously calculated from SEM images shows a good fit. These threshold porosity values between $2-4 \%$ were calculated at low magnifications (500 to 3,000 times). The Collingwood is most porous in the siliceous micrite and hardground (dolomitic) facies and least porous in the homogenized and shell debris facies. This is reasonable since dolomitization processes generally increase porosity, and that the sparite recrystallization and large amount of bioclasts in the shell debris facies will provide less porosity. Higher porosity in the siliceous micrite facies may also be attributed to the structure of the calcite matrix being affected by silica and clay deposition in the form of detrital clasts.

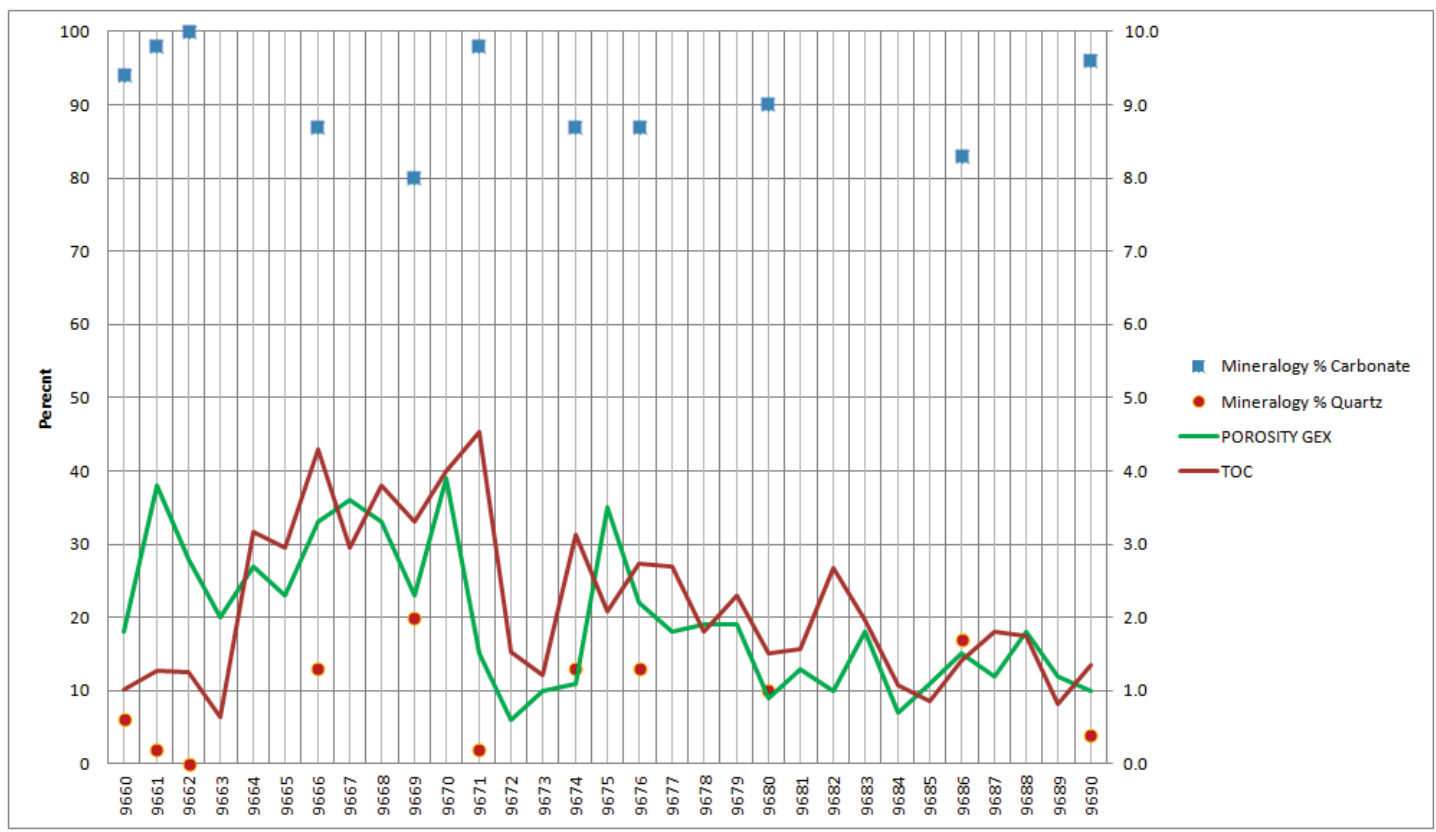

Figure 7.1: Core measured porosity and TOC (solid lines) against carbonate and silica XRD mineralogy (I/C) computations (markers). JEM Petro Corporation, Bruggers No. 3-7 (API: 21113-34078-0000), Missaukee County, MI. Core depth shown in feet. 
The siliceous micrite facies is also the richest in organic content and although kerogen was not easily visible it may have a large role in porosity generation. It also appears that based on core measured porosity (effective) and total porosity observations that there is likely very little non interconnected porosity in the Collingwood.

If we look at trends of core measured porosity vs. TOC we see what appears to be a correlating relationship (figure 7.1). This correlation suggests that porosity in this facies is directly related to kerogen content, as these values are not from wireline tools and not susceptible to hydrogen saturation effects. Carbonate and quartz concentrations are again shown to illustrate their trend with porosity as mentioned previously.

To contrast the Collingwood, the underlying Trenton as observed in our data has very low porosity. Core measured porosity is less than $1 \%$ as shown in laboratory measurements. The overlying Utica Shale however displays values reaching $8 \%$ porosity. The porosity structure of neighbouring formations is unknown since samples were not prepared for imaging.

\subsection{Permeability}

Core measured data from the Collingwood interval suggests that there is very little permeability available. Vertical permeability measurements universally are very low $(<0.1$ md (millidarcy)) highlighting the finely laminated, fissile nature of deposition. Outlier values of 90 degree permeability range from 1-7 md showing some zones of enhanced permeability. Finally, maximum permeability measured ranges from 0.1-13 md showing zones of developed hydraulic communication.

The JEM Bruggers 3-7 for example, has a maximum permeability of $3.1 \mathrm{md}$ at the hardground contact (9,660' core depth) and an overall average of $0.2 \mathrm{md}$ max permeability from 30 measurements made from 9,660' to 9,690' at one foot intervals. The JEM Weingartz 1-7A has a maximum permeability of $13 \mathrm{md}$ at a depth of 10,095' near the top of the unit and averages $1.9 \mathrm{md}$ max permeability from 19 measurements at one foot intervals throughout the core.

\subsection{TOC and Geochemical Data}

TOC content of the Collingwood is significantly higher than surrounding strata. The Collingwood is a very dark limestone, displaying its high kerogen content visually when contrasted with the Trenton. Pyrolysis calculated values from the three deep basin wells provided by MGRRE show the Collingwood to range from 1-6\% in TOC by weight. The upper part the section in the siliceous micrite facies has the highest recorded values of TOC. The homogenized facies is generally lower in TOC and is physically concentrated near the base of the unit. TOC content also drops near the top of the Collingwood in the hardground facies and in the shell debris facies. The JEM Bruggers 3-7 averages overall with a TOC wt\% of 2.215 while the upper third of its section from 9,660-9,670' averages to $2.92 \%$. It is likely that the lack of fossil debris and environmental preservation or production mechanisms associated with the laminate mud facies are responsible for its elevated organic content. 
The Utica Shale sampled in these data show TOC wt\% ranges from $0.5-1.5 \%$, statistically less rich than the Collingwood. The reasons for the change in TOC concentration are speculative. It is possible that either the production rate of organic material dropped, the sedimentation rate increased, or that the environment that fostered preservation changed. It is beyond the scope of this project to ascertain which of these mechanisms resulted in the change of TOC wt \%. It is however worthwhile to note this fact and the complementary data from the Trenton Formation showing values less than 1\%. This indicates that preserved organic material does not occur until Collingwood and Utica time.

The Collingwood in the deep basin is thermally mature as indicated by core and pyrolysis data. One such computed result from this data, the production index (PI), is used to characterize the evolution of organic matter, or the generative capabilities of a source rock. The PI is calculated by taking the amount of free hydrocarbons (S1) generated during pyrolysis and dividing it by the sum of free hydrocarbons and subsequently generated hydrocarbons (S2) from the thermal cracking of non volatile organic material. This quotient is then an indicator of the generative evolution of a source rock. A higher resulting value indicates that more hydrocarbons have been generated. The average PI value for the JEM Bruggers 3-7 in Missaukee County is 0.375 indicating that a good deal of the generative capabilities of the Collingwood have been exhausted. The JEM Weingartz 1-7A and Hunt Winterfield Deep Unit A-1 have PI's of 0.411 and 0.446 respectively and are more evolved. Hydrogen and Oxygen indices (HI, OI, measurements of organic material concentration and origin) in the JEM Bruggers 3-7 average to 23 and 16 respectively over the Collingwood. The more mature Hunt Winterfield Deep Unit A-1 shows averages of 11 and 15 for hydrogen and oxygen indices.

Using the pyrolysis data and converting TMax values to CAI equivalencies and using Hogarth and Sibley's CAI data for the Trenton Formation we were able to construct a rough approximation of thermal maturity across the northern part of the Michigan Basin for the Collingwood (Hogarth and Sibley, 1985). The result shown in figure 7.2, gives a general oil/gas window somewhere around the southernmost border of Antrim, Otsego, and Montmorency counties. This estimate has been supplemented by available production data in Cheboygan and Missaukee Counties of liquid oil and dry gas/condensate respectively.

In addition, the Collingwood in Canada as studied during the OSAP has shown to be very organic with TOC values of up to $11 \%$ and has produced liquid hydrocarbons as oil (Macauley and Snowdon, 1984; Barker, 1985). The PI values in Canada range from a very mature 0.57 in the Ottawa area to a very immature 0.06 at Manitoulin Island. This shows the vast differences in maturation of the Collingwood across the Canadian province of Ontario. kerogen content in Ontario has been identified as a mixture of Type I and II kerogens (Macauley and Snowdon, 1984). In the Michigan Basin, due to high maturity in the deep basin, kerogen classifies as a Type IV or inertite based on HI/OI cross plots from pyrolysis data. 


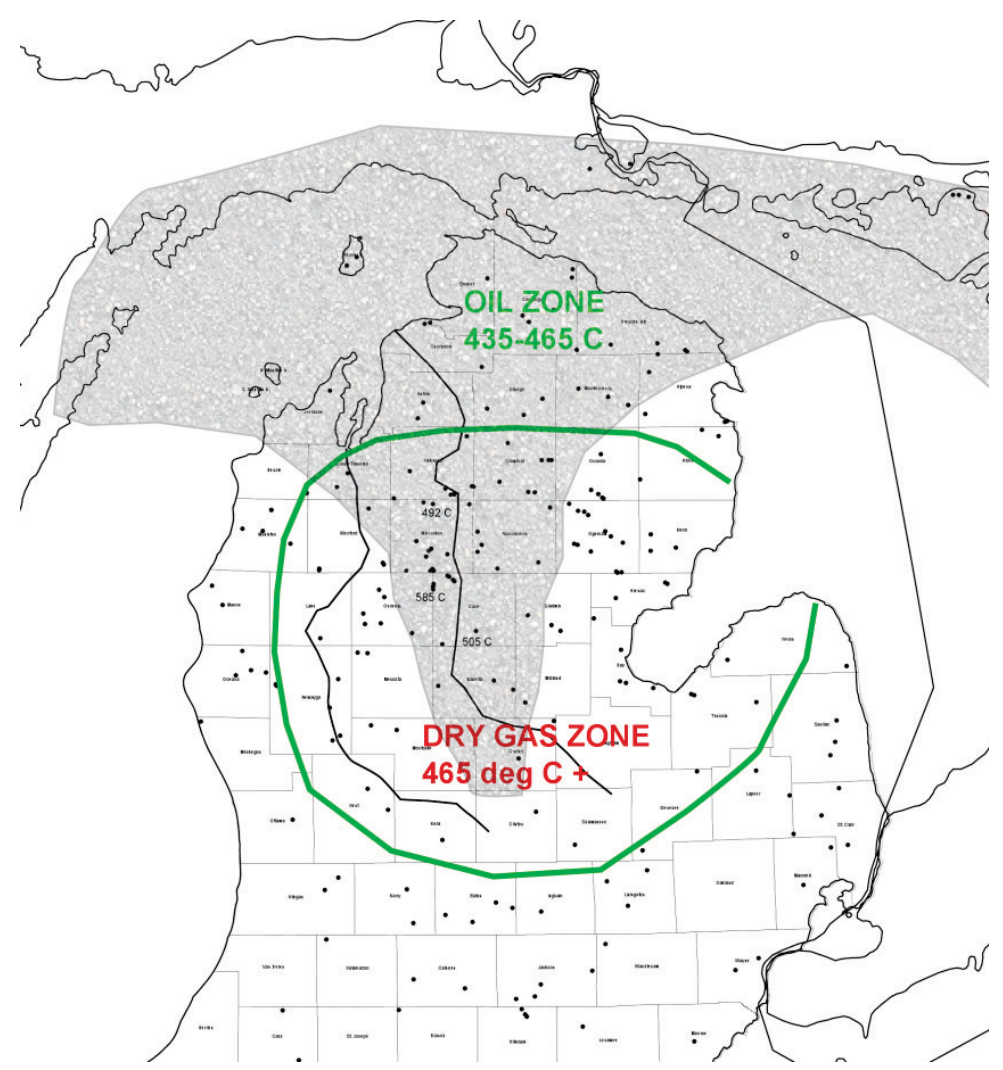

Figure 7.2: Estimated Oil \& Gas Window for the Collingwood calculated from Trenton Formation Conodont Color Alteration Index Data (Hogarth and Sibley, 1985) and pyrolysis data. Temperatures shown are pyrolysis TMax values in degrees Celsius. The shaded region represents the extent of the Collingwood Member. 


\section{Chronostratigraphic Correlation}

In 1978 Lilienthal published stratigraphic cross sections across the Michigan Basin as part of a Michigan Geological Survey Report of Investigation (\#19) (Lilienthal, 1978). In his dissection of the middle to upper Ordovician units he identifies and marks the top of a presumed metabentonite package "TG-1" in the Trenton Formation (figure 8.1). Lilienthal notes that "TG-1" is a correlatable bed and may be tracked throughout much of the basin. It is known that certain bentonite beds can be found as far away as the Upper Peninsula of Michigan in Chandler Falls of Escanaba and distributed across much of the Midwest (Delano, et al., 1990).

In an attempt to map a chronostratigraphic horizon through the Collingwood and Trenton, we have marked Lilienthal's TG-1 in as many of the geophysical well logs that were appropriate. Resulting inconsistencies have been found with using this bed as a chronostratigraphic marker in the Trenton. As an example, the overall character of the Trenton gamma-ray signature changes significantly between Clare and Roscommon counties moving in the northward direction. It is difficult to identify TG-1 and distinguish it between other high amplitude deflections in gamma-ray that are present.

Although basement depth does not change considerably in the transition between Clare and Roscommon counties the overall thickness of the Trenton does by approximately 80 feet (figure 8.2). In comparing two logs side by side from this region (figure 8.3) a series of high amplitude gamma ray spikes appear in the Roscommon County well approximately where TG-1 should be in the Clare County well. The Clare County well exhibits the typical Trenton gamma-ray signature that is seen in the thickest deposits in the south-eastern half of the Michigan Basin. This transition zone however results in the end of the expected gamma-ray character and the start of a more exotic, noisy variant that exists in the north-western half of the Michigan Basin.

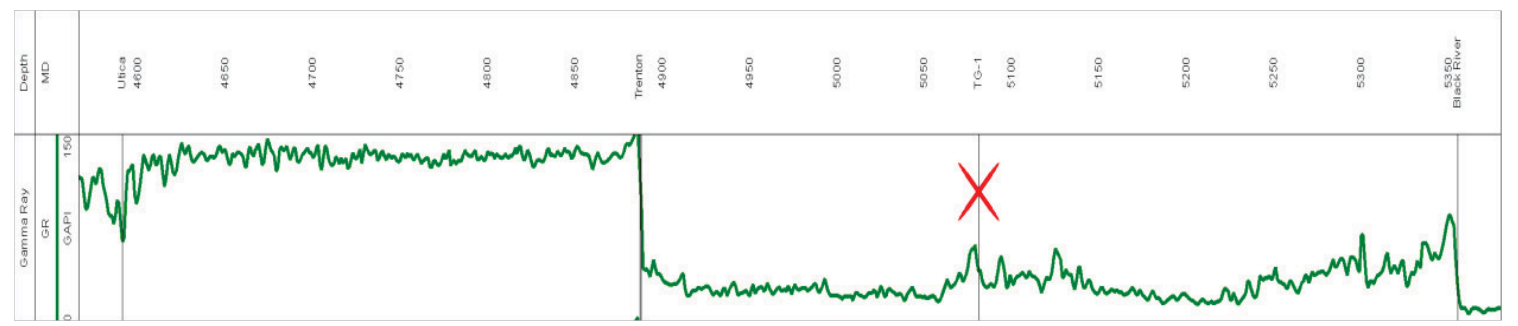

Figure 8.1: Typical Trenton Gamma-Ray Signature showing TG-1 (as indicated by red X), from Miller Bros. \& Atlantic Richfield, Arcon \& Patton 1-34 (API: 21-147-38965-0000), St. Clair County, MI. 


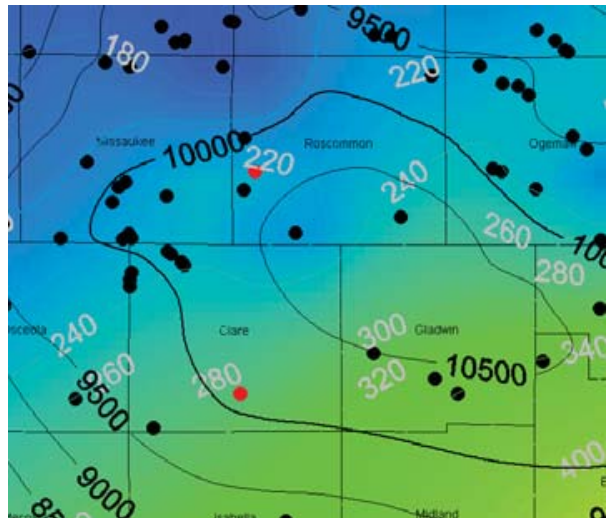

Figure 8.2: Selected wells in zone of thickness transition (Trenton Formation) highlighted in red (see figure 8.3). Black contours indicate burial depth (feet). Grey contours and colors indicate thickness of the Trenton Formation.

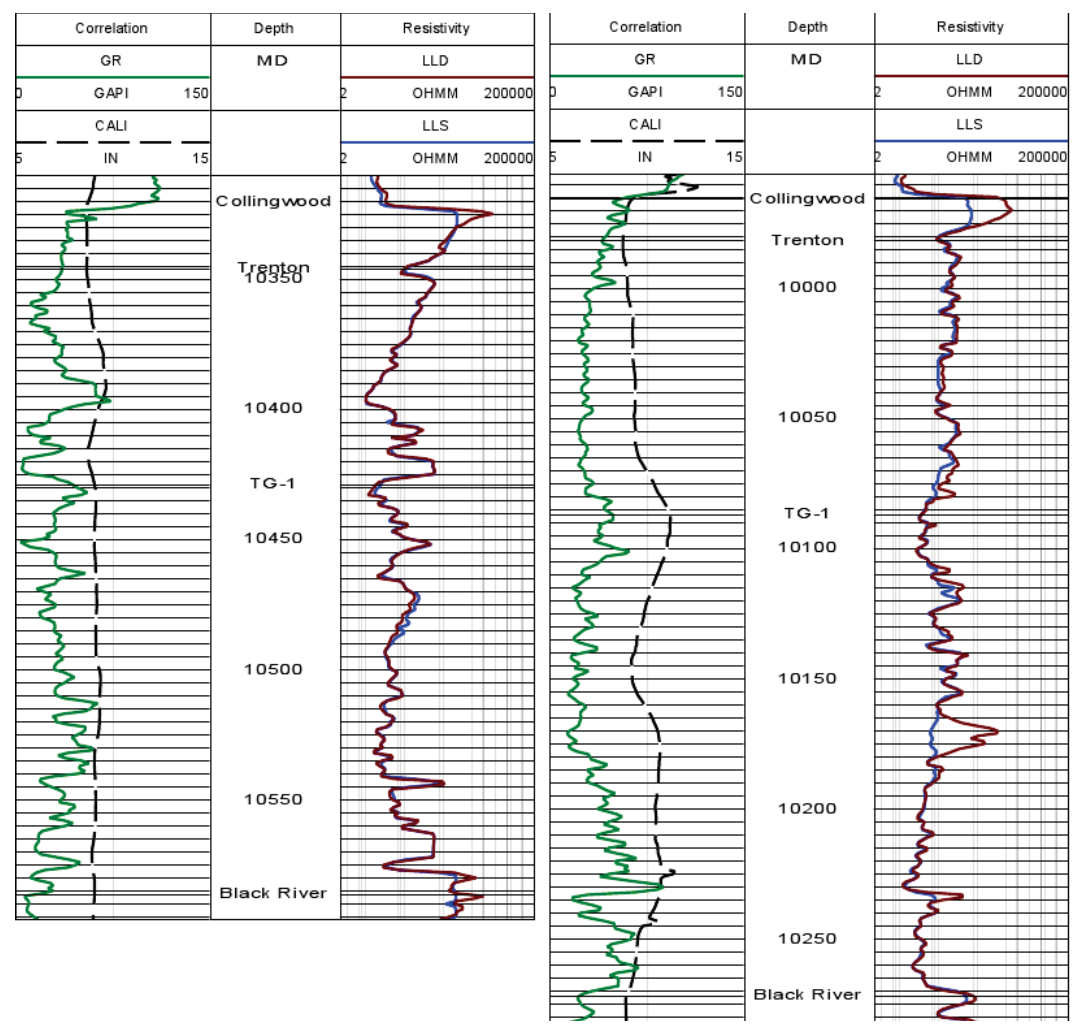

Figure 8.3: Gamma-ray, caliper, and resistivity logs for the Dart Oil and Gas Corporation, Dalrymple et al 1-16 (API: 21-143-34537-0000), Roscommon County, MI (left) and Marathon Oil Co., Weingartz et al 1-7 (API: 21-035-34611-0000), Clare County, MI (right). Well locations shown in figure 8.2.

Many of the wells in the transition zones are absent in Lilienthal's cross sections either due to logs not being available at that depth or ambiguity in selecting TG-1. Consequently this gap traverses a broad area of the Collingwood and clarification is important in order to develop a chronostratigraphic framework for the deposition of the Collingwood. 


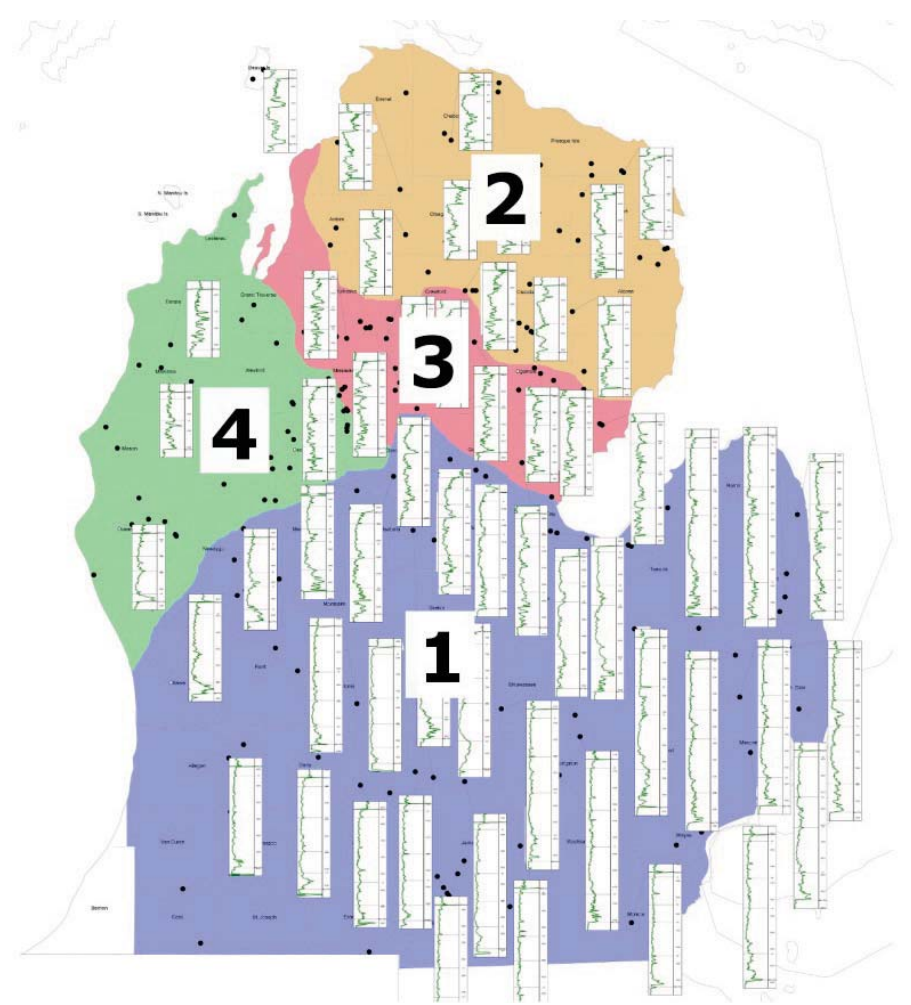

Figure 8.4: Correlative regions of gamma-ray in the Trenton Formation.

The gamma-ray signature in the northwestern half of the Michigan basin is noisy and difficult to delineate. It does however follow several distinct trends that can be observed in smaller regions depicted in figure 8.4. Region 1 corresponds to the carbonate platform and the typical Trenton gamma-ray signature that was shown in figure 8.1. Region 2 has a distinct shape with the most shallow, highest amplitude wedge thinning toward the northeast (of which the Collingwood is a part). Wells observed in regions 3 and 4 are also each respectively correlative, exhibiting their own unique gamma-ray signatures. An additional image of gamma-ray logs in the Trenton is available in figure 11.1.

One possible explanation for the behaviour of gamma-ray in the Trenton may be geologically related to a carbonate shelf margin that was present during the time of deposition (Wilson et al., 2001). Wilson et al have noted via well cores that the Trenton Formation is darker and more argillaceous in the north-western half of the basin as opposed to the southeast consistent with appropriate criteria to identify a carbonate shelf margin (Flugel, 2010). 


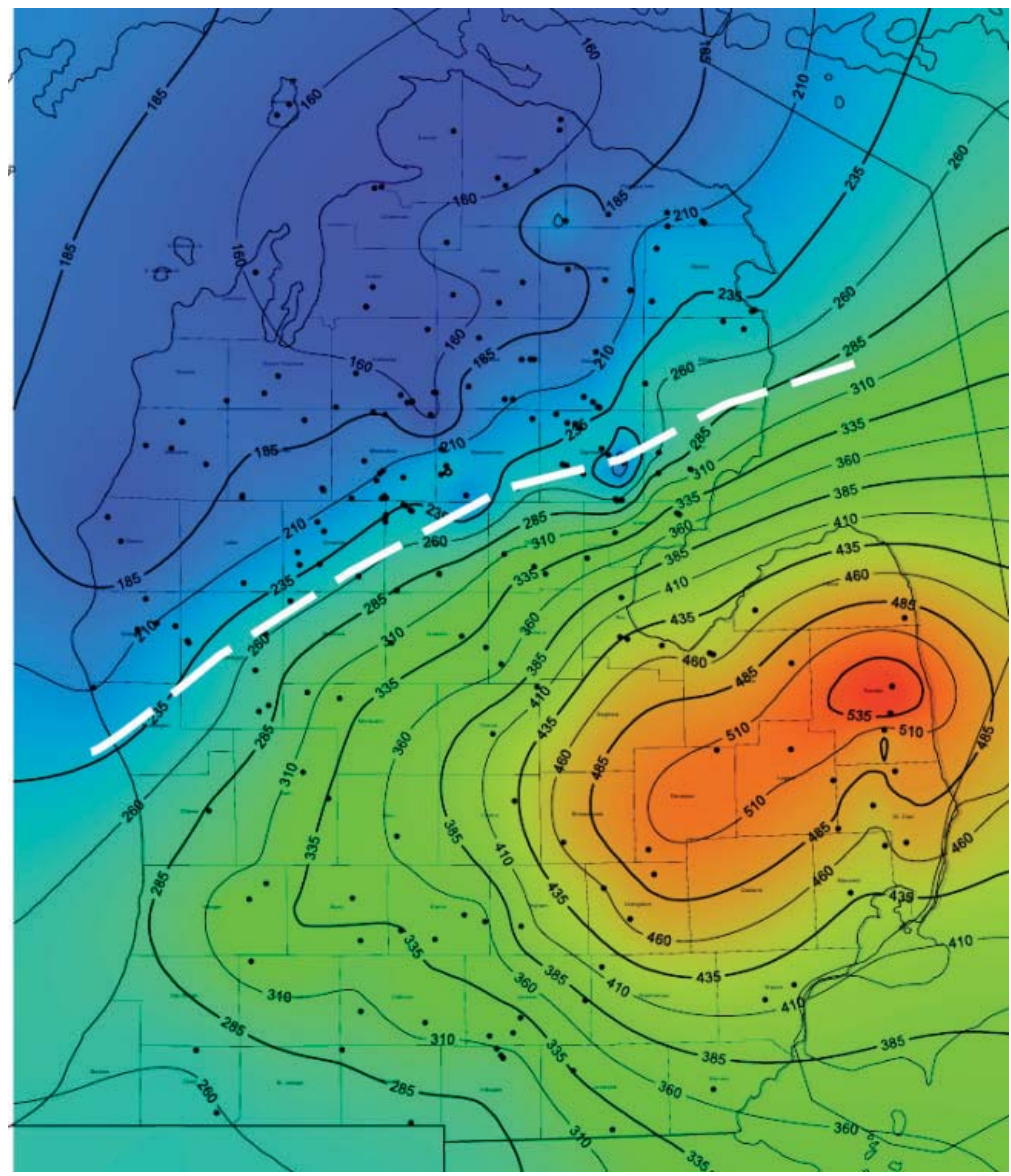

Figure 8.5: Isopach map of the Trenton Formation with contours and colors indicating thickness in feet. White dotted line indicates proposed location of carbonate shelf margin as discussed in accompanying text.

The south-eastern quadrant of the basin represents the thickest portion of carbonate deposition. It is possible that the low amplitude, thick deposits in this quadrant are a result of deposition keeping pace with subsidence and sea level changes and have been associated with a carbonate platform facies (Keith, 1988; Sharma et al., 2003). The south-western quadrant has thinner deposition and lower gamma-ray amplitude than the south-eastern quadrant; however their gamma ray signatures both correlate very well. The north-western half of the basin, where deposition is thinnest and most convolute, represents a deeper, more euxinic environment as interpreted by Wilson et al (Wilson et al., 2001). The thickness of the Trenton Formation is depicted in figure 8.5 illustrating the presence of a carbonate platform (lower right, red) and carbonate shelf margin (white dotted line). 
It is possible by examining the isopachs of the intervals Trenton (top) to TG1 and TG1 to Black River (top) (figure 8.7) to determine that there is relatively little change in depocenter between the two units. This suggests a consistent depositional environment across the basin throughout the entire Trenton sequence. Any possible environmental changes did not result in different deposition patterns on a large scale, however it is not known if metabentonite layers are consistently deposited in the Michigan Basin. In addition, it is not possible to determine whether or not the Collingwood was syndepositional with the top of the Trenton (in areas absent of the Collingwood), being unable to track the uppermost bentonites across the basin. It is also worthwhile to note that other authors have shown the Trenton and Utica formations to have been deposited syndepositionally in different areas of New York State (Goldman, et al., 1994). This alludes to the complexities of deposition and should be taken into consideration in order to develop an accurate model. A detailed mapping of bentonites in the Trenton Formation of the Michigan Basin may yield answers to some of the proposed questions.

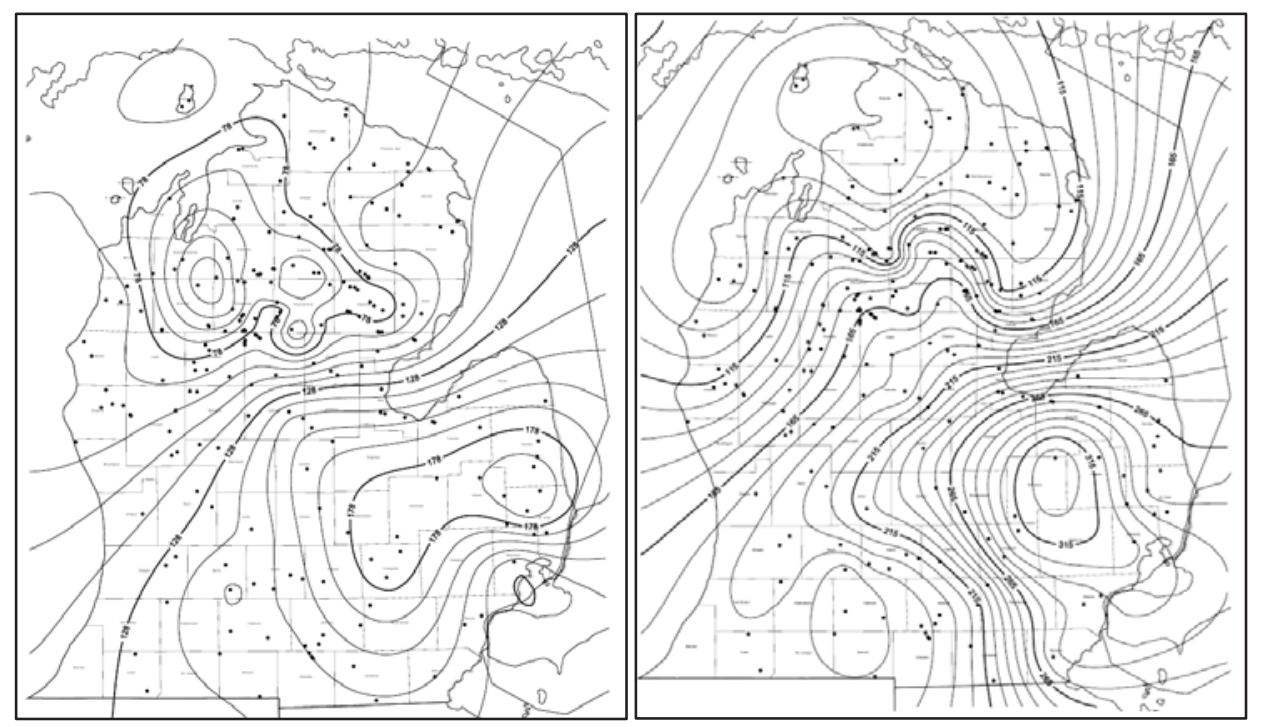

Figure 8.6: Top of Trenton Formation to TG-1 isopach (left) and TG-1 to top of Black River Formation isopach (right). The thicknesses values depicted by contours are shown in feet. 


\section{Petrophysical Response}

\subsection{The Trenton Formation}

The petrophysical response of the Trenton formation as a sequence is that of a typical carbonate. Gamma-ray amplitude is generally low with exceptions of high amplitude spikes (k-feldspar metabentonites) that are found throughout the Michigan Basin. Specifically, these deflections are most visible in the carbonate platform where they contrast in the thick, low amplitude, and clean limestone.

In the north-western half of the basin the Trenton has a much noisier, higher amplitude gamma-ray signature due to clay and organic material in a more euxinic environment (Wilson et al., 2001). In general, the overall trend of the Trenton's gamma-ray amplitude is to increase toward the northwestern half of the basin as shown (figure 9.1).

The resistivity response of the Trenton formation varies regionally. In some areas of the Michigan Basin and subsurface Ontario, the Trenton may act as a reservoir or may be self sourced (Rancourt, 2009). Reservoirs typically have been observed in specific fields such as the Albion-Scipio of southcentral Michigan. Although there is a possibility for kerogen or hydrocarbon saturation in the Trenton in the areas of the Michigan Basin where the Collingwood is also present, it is has been observed that it is not typically the case. The Trenton Formation generally has a low resistivity with any large amplitude variations near the Collingwood contact. Invasion profiles have also been noted to be very small in the Trenton, shown by a low separation of deep and shallow resistivity readings in logs.

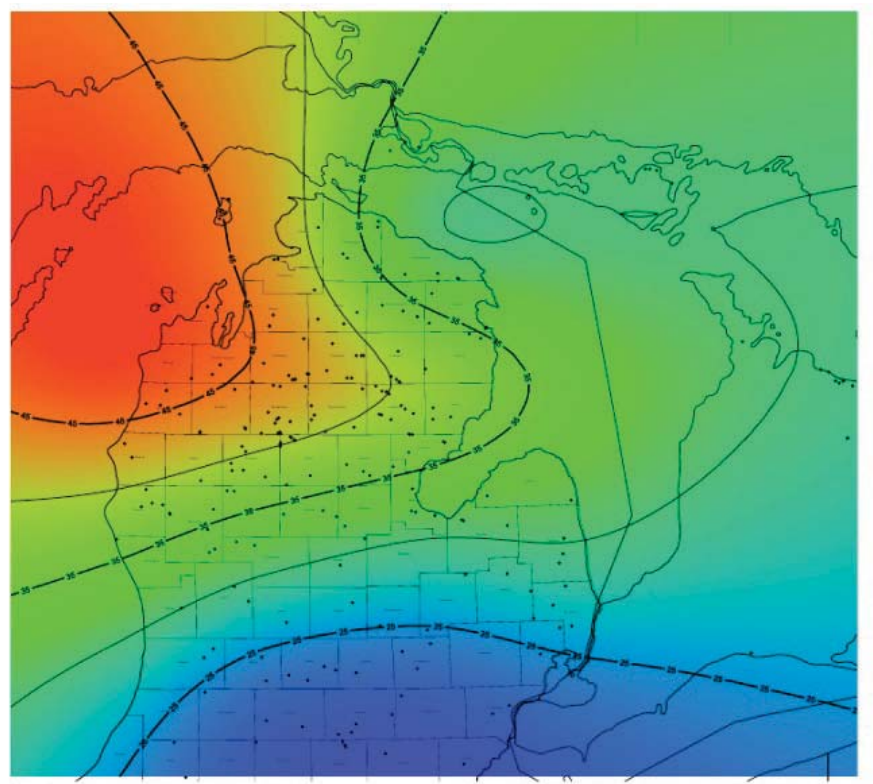

Figure 9.1: Trenton Formation gamma-ray amplitude trend shown. The gamma-ray value is computed as an average over the entire interval. Contours and colors indicate amplitude in GAPI. The highest gamma-ray amplitudes are shown in red. 
Neutron porosity readings are typical of that of a tight limestone due to low physical porosity and lack of hydrocarbon, kerogen, and bound water effects. In essence, since most neutron porosity tools are calibrated in a $100 \%$ limestone matrix saturated with water, the porosity readings in the Trenton are assumed to be very close to actual values where it is known to be a clean limestone. Other areas in the Trenton that may contain appreciable levels of dolomite, silica, clay, or organics would require a more detailed calibration of neutron porosity readings.

Sonic response in the Trenton is fast due to compaction, low porosity and regional dolomitization ranging between 50-60 us/ft. Bulk density values typically trend near the limestone value of 2.71 and may increase in dolomitized zones. Caliper readings in the Trenton generally appear to increase when compared to the overlying Collingwood and Utica. The exact reason for this is unknown, but it may be related to the formation solubility in drilling mud or brittleness resulting in drill string damage. Finally, the Trenton has displayed very low levels of organic content throughout the majority of its sequence with exceptions immediately near the Collingwood contact.

\subsection{The Collingwood Member}

When transitioning into the Collingwood Member from the Trenton formation petrophysical response is generally indicative of a source rock resulting in elevated resistivity, neutron porosity, and sonic transit time. Bulk density readings are conversely very low when assuming a pure carbonate matrix. The nature of this response is due to adsorbed hydrocarbons, kerogen, and higher porosity when compared to the inorganic, tighter limes of the Trenton.

The gamma-ray signature of the Collingwood varies regionally. It is generally noisy and relatively high amplitude (approximately 50-90 GAPI) due to clay and organic content. In most cases, the Collingwood can be easily distinguished from the Utica (100+ GAPI) and Trenton ( $<50$ GAPI) by its gamma-ray amplitude which is between the two. It should be noted however, that when evaluating gamma-ray readings in the Collingwood it is suggested that they should not be used as an indicator of shaliness (Glover, 2000).

The nature of the source of the gamma-ray content in the Collingwood can be speculated from one spectral gamma-ray log that was found to be available from the Hunt Energy Winterfield Deep Unit A-1 well in Clare County (summarized in table 4). This log shows that transitioning from the Trenton into the Collingwood Thorium (Th) and Uranium (U) content rose $55 \%$ while Potassium (K) only $3 \%$. Low $\mathrm{K}$ content may indicate a Th rich clay and $\mathrm{U}$ content is likely related to organic material (Glover, 2000). 
Table 4: Spectral gamma-ray data summary from Hunt Energy Corporation, Winterfield Deep Unit A-1, (API: 21-035-33680-0100), Clare County, MI.

\begin{tabular}{|l|l|l|}
\hline \multicolumn{4}{|l|}{ Collingwood Averages } \\
\hline THOR ppm & URAN ppm & POTA \% \\
\hline 3.041768 & 2.836506 & 1.11276 \\
\hline Trenton Averages & 1.08005 \\
\hline 1.956434 & 1.833144 & 3.028373 \\
\hline Percent change between Collingwood and Trenton \\
\hline 55.47509 & 54.73446 & \\
\hline
\end{tabular}

Utilizing Th/K crossplots (Charts Lith 2/CP-19 from Schlumberger (Schlumberger, 2005)) we can also perform clay typing from the spectral gamma-ray data. In the Hunt Energy Winterfield Deep Unit A-1, an average of $1 \% \mathrm{~K}$ and $3 \mathrm{ppm}$ Th indicates mica and chlorite zones suggesting an illite dominant clay, which was physically observed. In computed mineralogy I/C analysis we found iron chlorite compromising approximately half of the clay total. No environmental potassium corrections were made for drilling mud that was documented as "brine" on the well log header. It is worthwhile to note is that it is also possible that elevated Th is related to quartz silt beds or organic-rich beds as an insoluble residue (Lucia, 2007).

Facies in the core can also be estimated from gamma-ray. In the JEM Bruggers 3-7 the hardground, shell debris, and homogenized facies have low gamma-ray amplitudes. The siliceous micrite or laminated mud facies has higher gamma-ray amplitude by comparison. Plotting this data together (figure 9.2) and comparing it to the core section allows us to verify the trending between gamma-ray and facies changes. In this way, gamma-ray can be a useful tool in order to construct a rough approximation of facies.

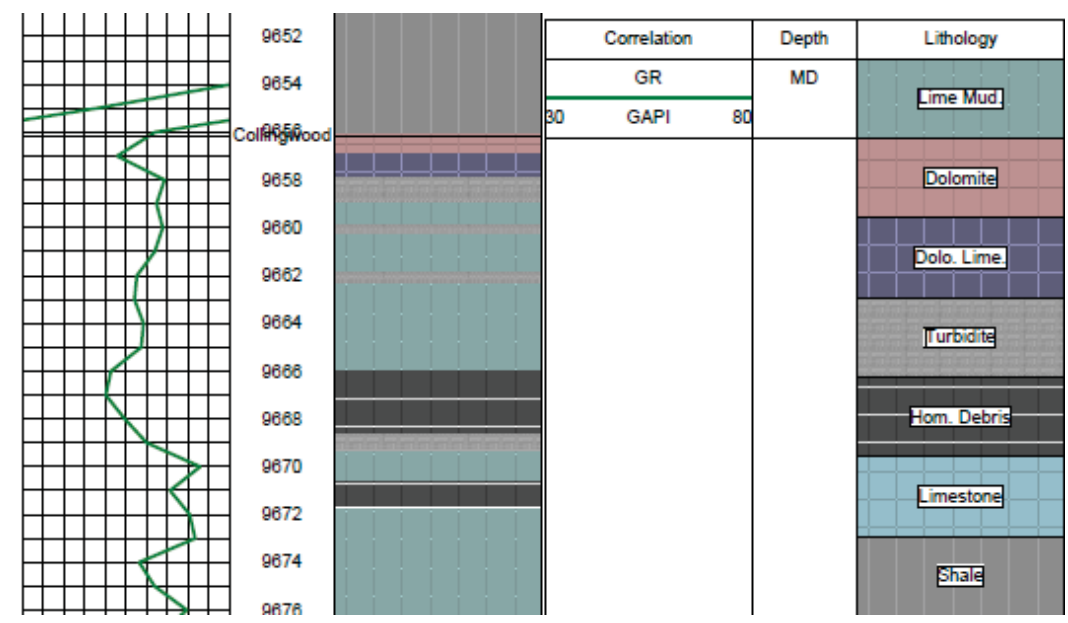

Figure 9.2: Facies and core lithology depicted against wireline gamma-ray. JEM Petro Corporation, Bruggers No. 3-7 (API: 21-113-34078-0000), Missaukee County, MI. Log depth shown is 4' shallow relative to core depth. 


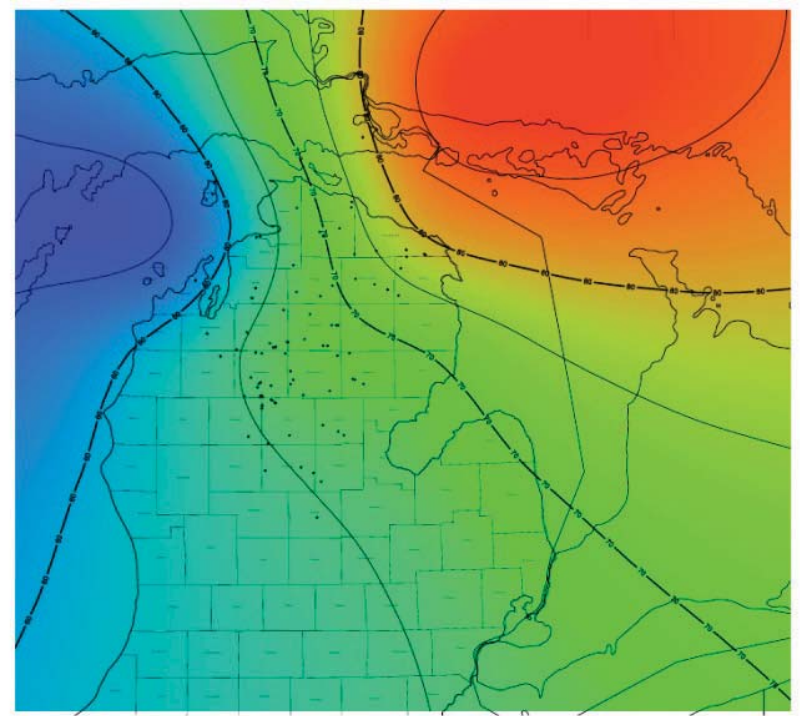

Figure 9.3: Collingwood Member gamma-ray amplitude trend shown. The gamma-ray value is computed as an average over the entire interval. Contours and colors indicate amplitude in GAPI. The highest gamma-ray amplitudes are shown in red.

The regional pattern of gamma-ray in the basin shows the Trenton to have maximum amplitudes in the northwestern half of the basin and the Collingwood in the northeastern quadrant (figure 9.3). In the case of both formations being primarily carbonate, the reason for the change in trending of gamma-ray amplitudes is unknown. It may be speculated however that the deeper, more euxinic environment of the Trenton may be responsible for its elevated gamma-ray signature (Wilson et al., 2001). In the Collingwood, elevated concentrations of organic material (11\% TOC) and clay content (15\% iron chlorite/illite) that have been observed in Canada are likely responsible for the nature of its gamma-ray trend (Macauley and Snowdon, 1984; Rancourt, 2009).

The Collingwood, as a source rock is organic rich and has a very high resistivity deflection across its section due to adsorbed hydrocarbons and kerogen. This resistivity profile is an excellent indicator in indentifying the formation in geophysical logs. Care should be taken however as noted by Rancourt that "self sourcing" areas of the Trenton Formation of southwest Ontario (where the Collingwood is absent) are stratigraphically correlative with the Collingwood in the Michigan Basin (Rancourt, 2009).

The overall character of the resistivity response of the Collingwood is regional. It may appear as a gradual increase or decrease, a sharp spike, or a doublet. The doublet profile has been observed in many wells (including cored ones) and corresponds to a zone of low organic content in the laminated mud facies (figure 9.4). Invasion profiles were calculated from non clipped well log suites with microresistivity measurements. From the Newport, Roseville Gun Club "B" 1-17 (API: 21-143-374090000) in Roscommon County using Tornado charts a 35" depth of invasion was calculated in the Collingwood at approximately 10,870' with 9.3 ppg mud. The Fairway Petroleum, McNeel 1-8 (API: 21-073-40823-0000) in Isabella County was calculated to have 15-20" invasion depths in the Collingwood at approximately 8,900'. The Trenton formation generally does not exhibit high separation of resistivities. 


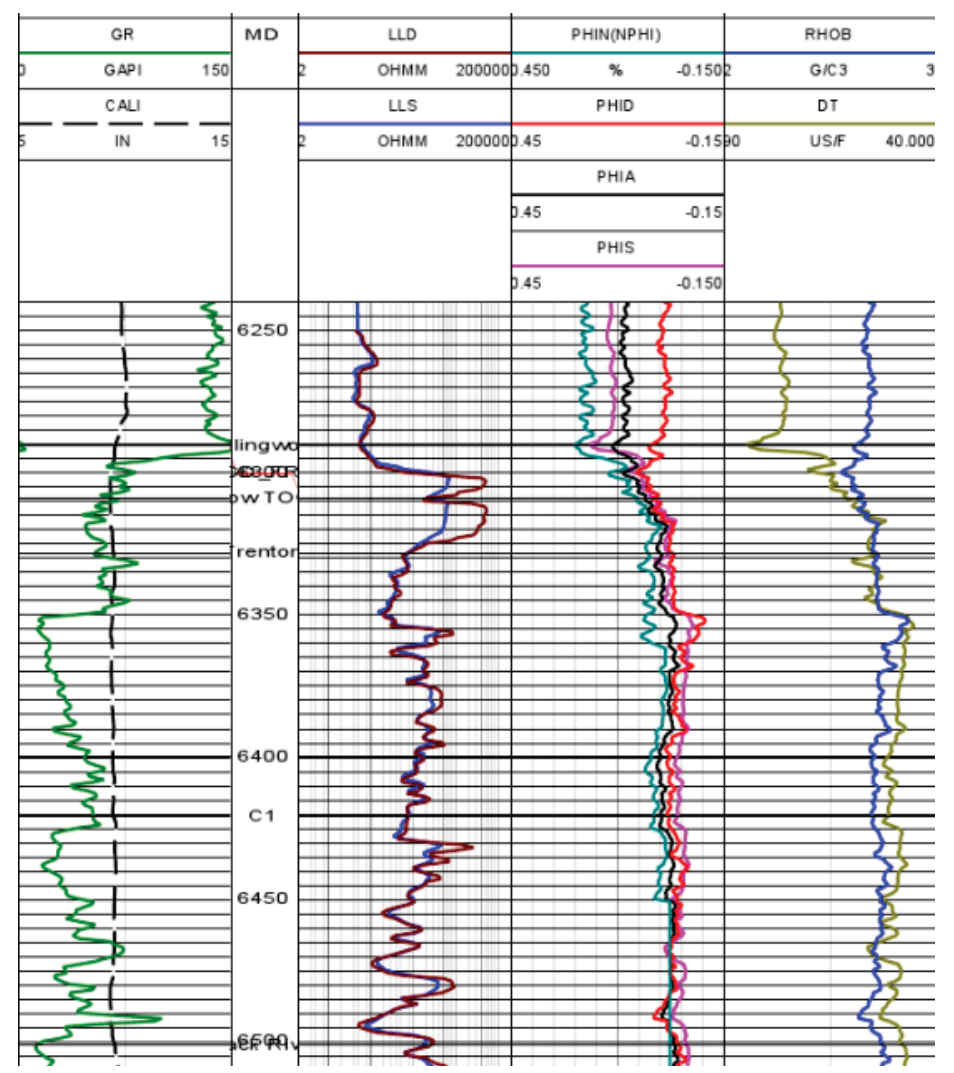

Figure 9.4: Log suite from Collingwood to Black River interval. The characteristic resistivity doublet is visible in the second track. Energy Acquisition Corporation, North Michigan Land \& Oil Corp. 1-27 (API: 21-029-34824-0000), Charlevoix County, MI.

The Collingwood has an elevated neutron porosity response due to hydrogen rich kerogen, generated fluids (petroleum), and physical porosity. The overall readings are generally much higher than the underlying Trenton and lower than the Utica (due to bound water in clays). An error is introduced to calibrated neutron porosity measurements which accurately respond to only a $100 \%$ limestone matrix filled with water. This error is manifested by the lithology and source rock nature of the Collingwood deviating from a non-organic limestone. Laboratory measured core porosities are much lower than calculated porosities on wireline logs. The true porosity of the Collingwood is therefore bound by the laboratory measured and wireline measured porosity values.

Sonic porosities are computed the highest using a Wylie time average (accounting for 90\% calcite, $10 \%$ quartz matrix and DTMa of 50, DTfl of 189). It is questionable how much kerogen and silica effect sonic velocities and how to adjust these values. Neutron-density average computed porosity seems the most appropriate as it averages error from both tools and trends very well with core measured porosity after corrections.

Comparing core measured porosity, lithology, and petrophysical log curves to each other has yielded trends with various facies in the Collingwood. For example, we find that the dolomitic hardground surface that was previously identified as having a high porosity in core measurements reads very low 
in wireline logs. This may be explained by low tool resolution and the thin nature of this facies. The shell debris and homogenized facies also show relatively low porosity values in wireline logs. The most porous zone in the Collingwood is the finely laminated micritic facies, not only having a high core measured porosity, but also wireline porosity due to high TOC content and its effect on tool response.

Bulk density is a very useful indicator of the Collingwood in wireline logs. The source rock nature of the Collingwood causes values to deflect against the underlying Trenton due to: (1) kerogen content; (2) silica content; and (3) adsorbed hydrocarbons. A simple method of visualizing the Collingwood can be done by highlighting lower deviations from a value of 2.71. An example is shown in figure 9.5. Bulk density derived porosity was also examined on large scale and typically exhibits the lowest porosity estimate as compared to neutron and sonic derived values (figure 9.6). Values also correlate very well with TOC due to the effect of low density kerogen $\left(\sim 1.2 \mathrm{~g} / \mathrm{cm}^{3}\right)$ on tool readings.

It is worthwhile to note that in the overwhelming majority of calliper logs examined the Collingwood appears to maintain borehole stability. In some cases washouts have been observed at the UticaCollingwood contact and borehole size may change slightly traversing into the Trenton. Overall however, logs suggest a high level of confidence in pad-style lithodensity readings in the Collingwood interval due to favourable borehole conditions.

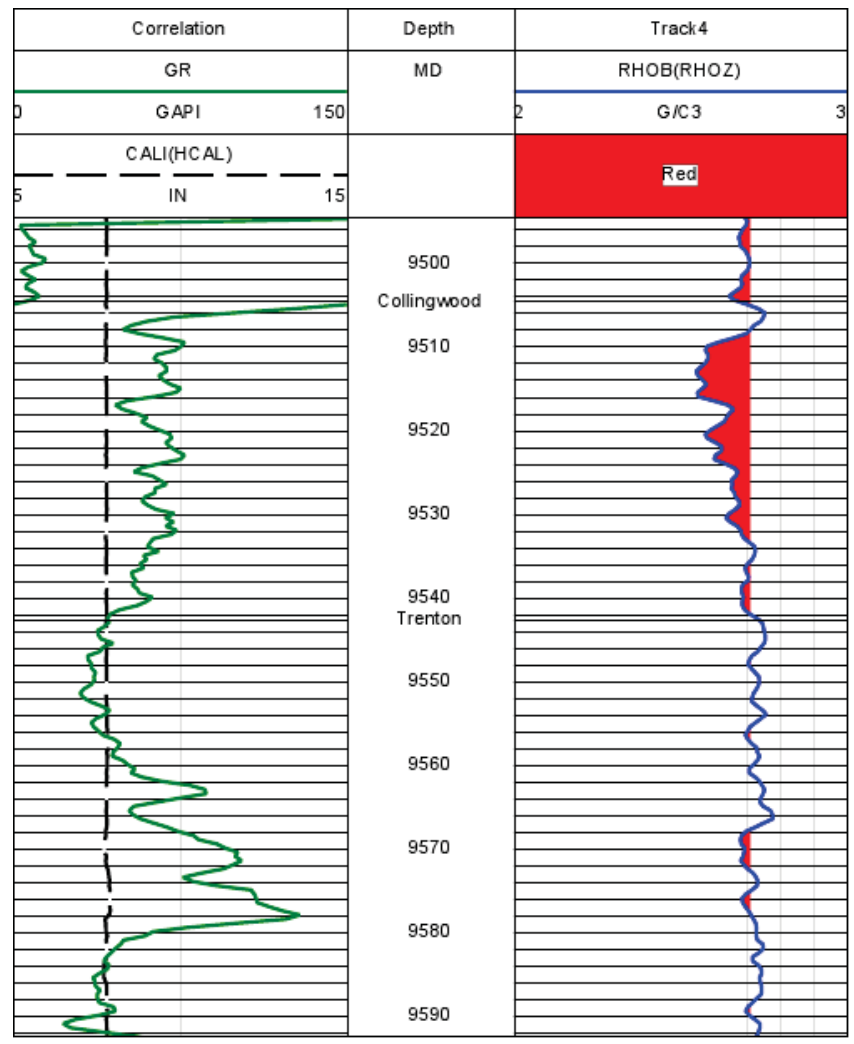

Figure 9.5: Log suite showing bulk density deviation from limestone standard $\left(2.71 \mathrm{~g} / \mathrm{cm}^{3}\right)$ shaded in red. Petoskey Exploration LLC, State Pioneer 1-3 (API: 21-113-59919-0000), Missaukee County, MI. 


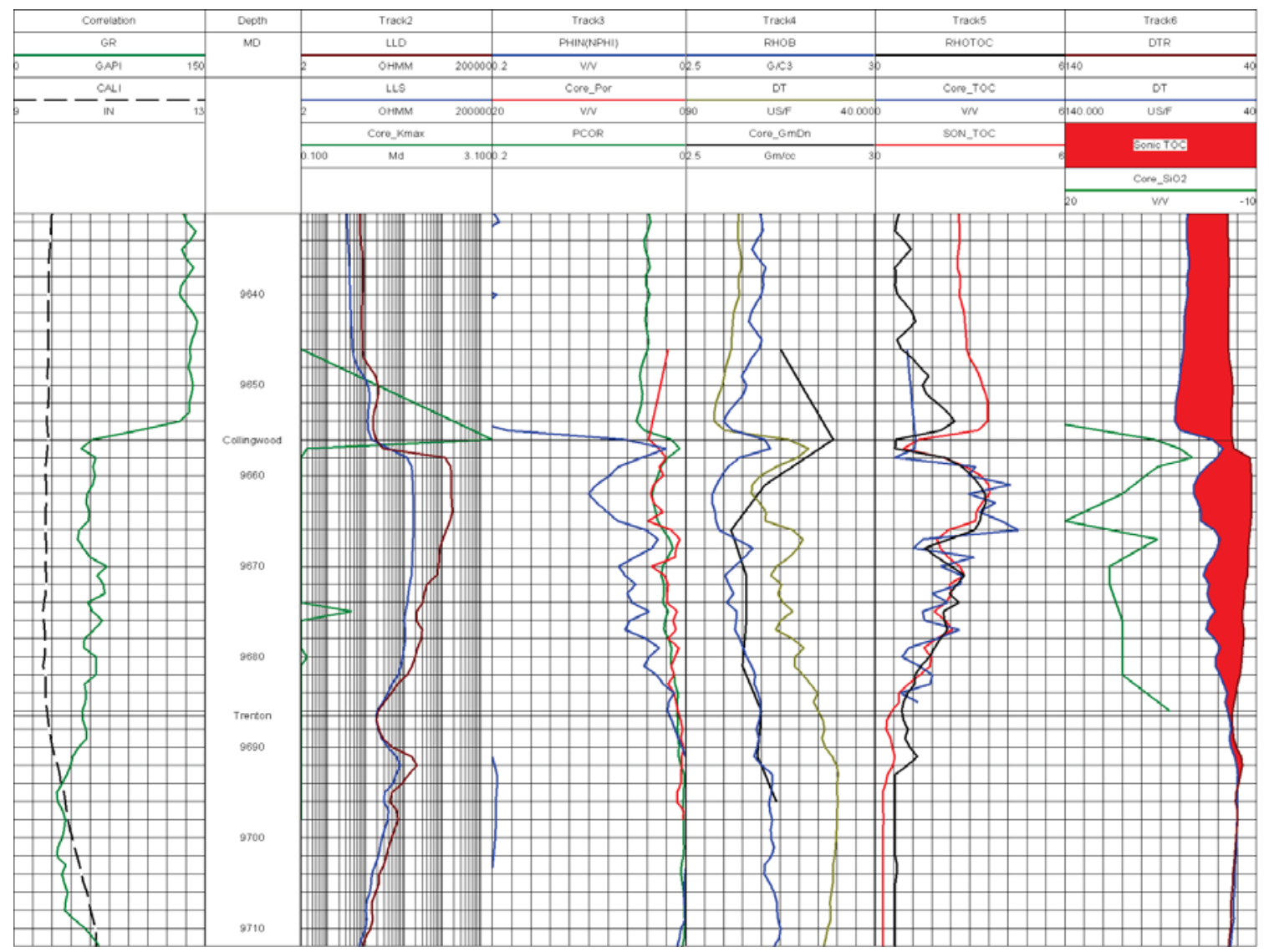

Figure 9.6: Full log suite, JEM Petroleum Corporation, Bruggers No. 3-7 (API: 21-113-340780000), Missaukee County, MI. Depth shown is log depth. Core data displayed depth shifted to match log depth.

The JEM Bruggers 3-7 was chosen to study due to its close proximity to the State Pioneer \#1-3, its good representation of the facies in the Collingwood, and a large amount of data available from a multitude of analyses (i.e. XRD, SEM, etc). The wireline tool response in the JEM Bruggers 3-7 is considered typical of the Collingwood as discussed previously in this section. There are several interesting features and trends however that became apparent after organizing the data together visually.

One such feature is an increase of permeability in the inorganic, resistivity minima of the 'doublet'. Another trend is that most measurements seem to track with the amount of silica contribution. There is not enough data available from other wells to make a generalized statement of these properties across the Collingwood as a whole. They should warrant further investigation and may prove to be useful in exploiting the Collingwood to its full potential as a reservoir.

By understanding the response of wireline tools to the Collingwood we were able to define the best possible picks across the Michigan Basin (figure 9.7). Wellbore resolution was particularly poor in the northern basin region. In figure 9.7 it should also be noted that control points exist in the Upper Peninsula and St. Joeseph's and Manitoulin islands to restrict the contours. 


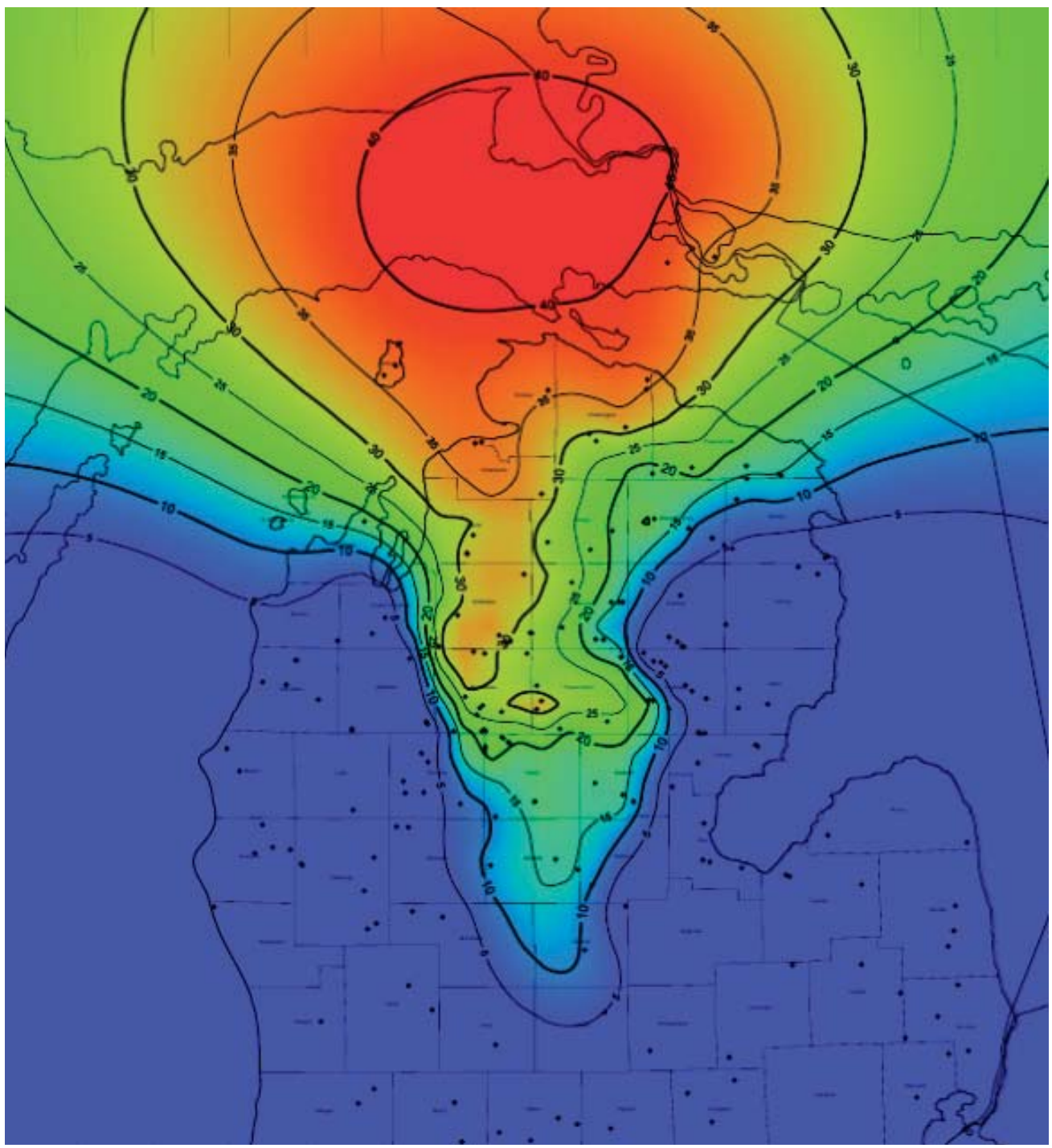

Figure 9.7: Isopach of the Collingwood Member. Thickness depicted in contours and color in feet. Black dots on image are wellbore data points used to constrain contours. Minimum curvature gridding algorithm used.

\subsection{The Utica Shale}

The Utica Shale overlies the Collingwood. It is composed with dominant silica and clay components and very little carbonate content. Gamma-ray readings in the Utica generally contrast very well against the Trenton where the Collingwood is absent, and against the Collingwood when present.

The Utica Shale has a high gamma-ray amplitude (100 GAPI+) contributed to from clay content and organic material. This is a very good indicator to use when picking the Collingwood-Utica contact. In the Hunt Energy Winterfield Deep Unit A-1 spectral gamma-ray log, it was observed that in the Utica Shale, the Th/K ratio increases much more dramatically than in the Collingwood indicating the presence of potassium rich clays as the primary source of radiation. 
Resistivity in the Utica Shale is relatively low even with some organic material present. In most examples where the Collingwood is present the Utica can be delineated by resistivity. In addition, elevated neutron porosity is a valuable indicator of the transition from the Collingwood to the Utica. The elevated neutron porosity values in the Utica are in response to bound water associated with clays. Sonic transit times in the Utica are typically much higher (slower velocities) than the Collingwood due to porosity, clay structure, and bound water.

Finally, bulk density measurements are not very useful since the composition of the unit renders a value approximately that of the Collingwood and Trenton. Although values are somewhat lower, they are the least useful of the measurements in making picks. 


\section{TOC Approximation}

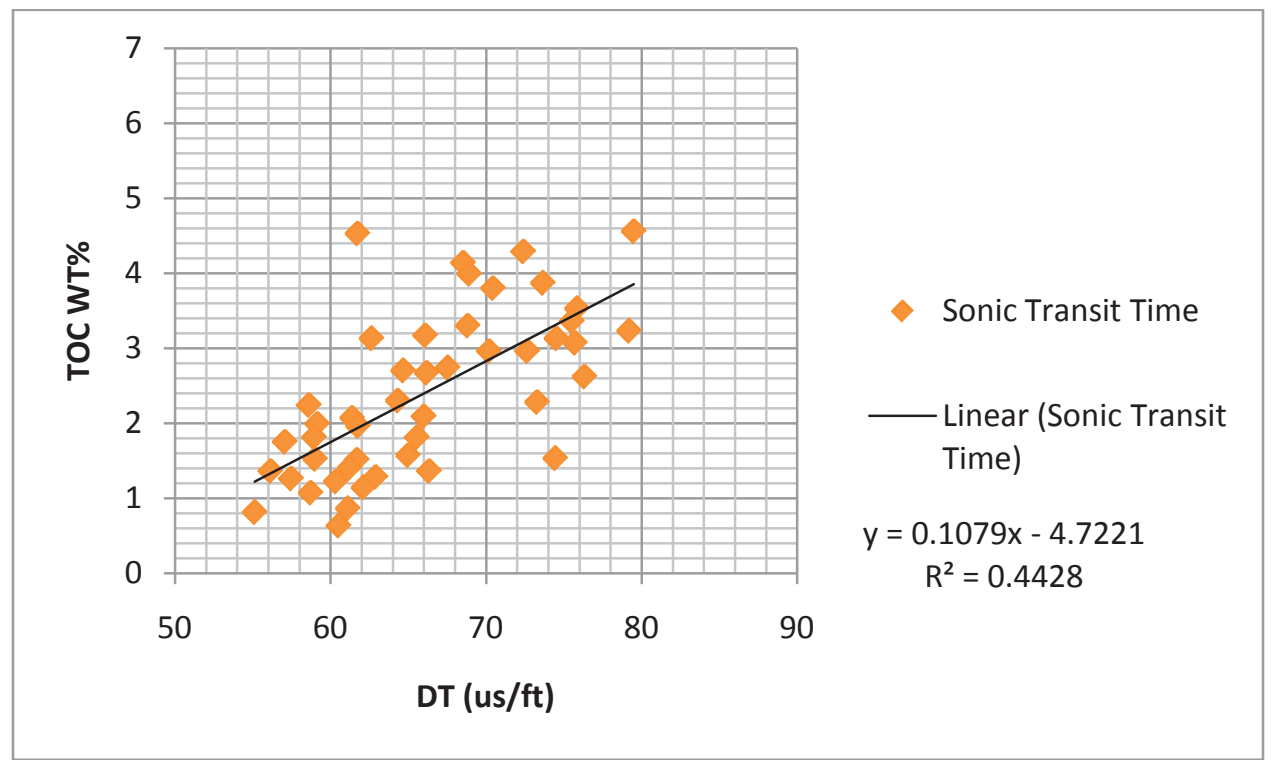

Figure 10.1: Linear regression computed for sonic transit time (from wireline logs) and TOC wt\% (from pyrolysis data) for both the JEM Bruggers 3-7 (API: 21-113-34078-0000), Missaukee County, MI, and Hunt Energy Winterfield Deep Unit A-1 (API: 21-035-33680-0000), Clare County, MI in the Collingwood interval.

Approximation of TOC values from commonly run log suites may be of value in evaluating a potential play across a broad region with limited core data. In following after Passey et al (Passey, et al., 1990), we developed a $\Delta \log R$ technique in the Collingwood by generating linear regressions in the underlying, mineralogically similar, but inorganic Trenton (Bowman, 2010) and using these to quantify deviations. It should be noted that Passey and others observed that sonic transit time (DT) seemed to be the best log measurement to use in this method as it was least susceptible to borehole effects (Passey, et al. 1990; Bowman, 2010; LeCompte and Hursan, 2010).

Core and log data for the three wells used in this study provided by MGRRE were plotted against TOC (wt \%) to examine linear relationships and how strongly they correlated. It was found that the best correlation was (as noted by Passey et al and Bowman) sonic transit time (figure 10.1). Gammaray does not have a very strong correlation as it is likely that the nature of response is related to both clay content as well as organic content, as we have previously seen from spectral gamma-ray data. Neutron porosity and bulk density measurements trend fairly well to TOC. Resistivity values are problematic in our suite of logs due to depth shifts during merging, slow tool response, clipping and borehole damage.

A problem with Passey et al's $\triangle \operatorname{LogR}$ technique to compute TOC is that it relies on a parameter, LOM, as given by the equation provided.

$$
T O C=\Delta \log R \times 10^{(2.297-0.1688 \times L O M)}
$$




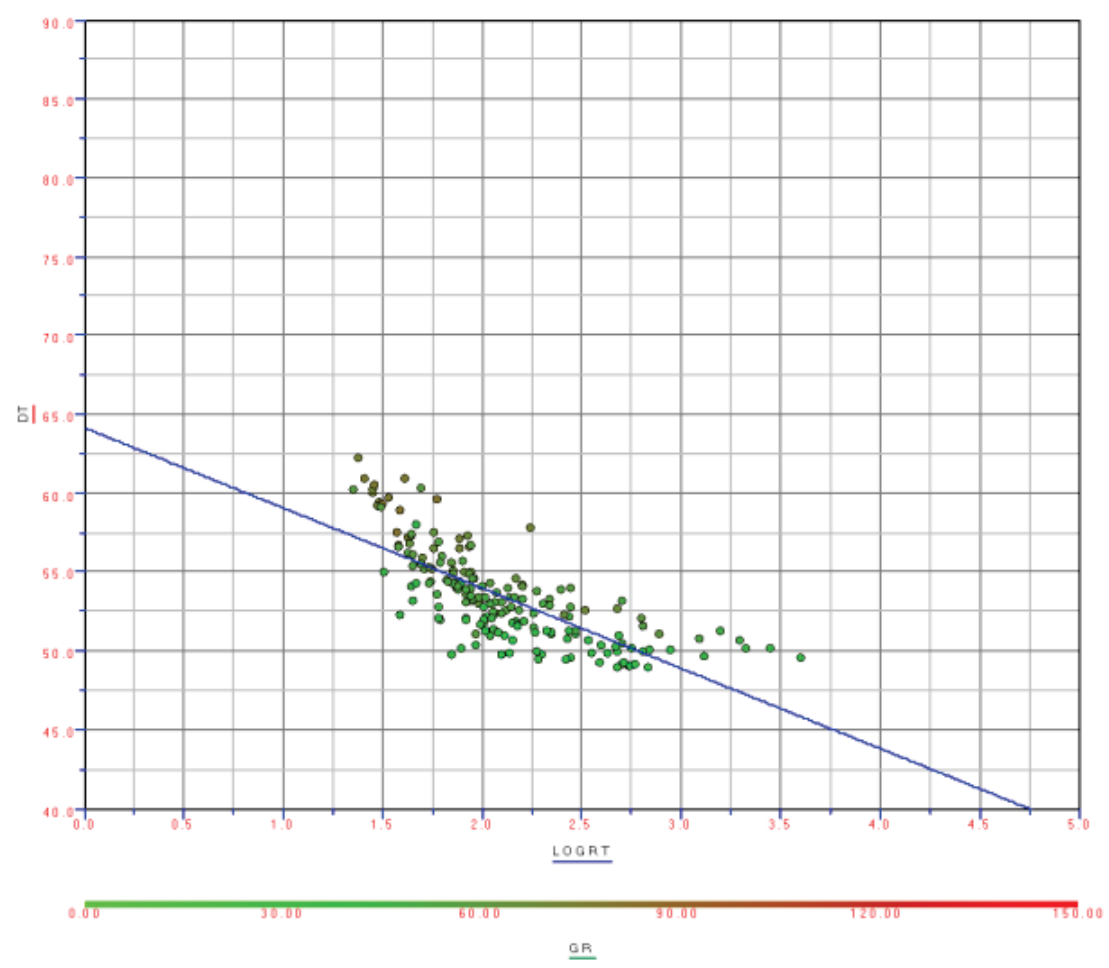

Figure 10.2: DT vs. $\log _{10}$ (Deep Lateralog Resistivity) and corresponding regression line (blue). JEM Bruggers 3-7 (API: 21-113-34078-0000), Missaukee County, MI.

There are several different methods (charts) available, provided by Passey et al and other sources relating various maturity indicators (Ro, TTI, CAI, etc) to LOM. It is somewhat impractical to zone this parameter to individual wells in the basin. If it is to be accounted for as a variable of thermal maturity, a proper thermal model needs to be developed. In any case, this technique was originally not intended for resource play evaluation, rather to identify and evaluate source rocks (LeCompte and Hursan, 2010) and such is treated as a rough approximation of TOC herein. In addition, Passey et al and other authors have also noted that the empirical equations provided for TOC calculation were calibrated for LOM values between 6 and 12 only. Subsequent values outside of this range cause over or under prediction of TOC. Corrections have been provided to these equations by other authors since (LeCompte and Hursan, 2010).

Following after Bowman, a more feasible, robust approach to the $\Delta \operatorname{LogR}$ method was employed using linear regressions. For each individual well, a regression was made with DT and RhoB against $\log _{10}$ of deep resistivity in the Trenton Formation (figure 10.2). The difference taken between the equation for this regression and actual log values in the Collingwood is then proportional to $\Delta \operatorname{LogR}$ as determined by Passey through overlays. We then took our proportional $\Delta \operatorname{LogR}$ values and used them in TOC calculations along with LOM values generated from a crude thermal model produced from CAI data. This TOC value was then calibrated to core data in the deep basin (figure 10.3). 


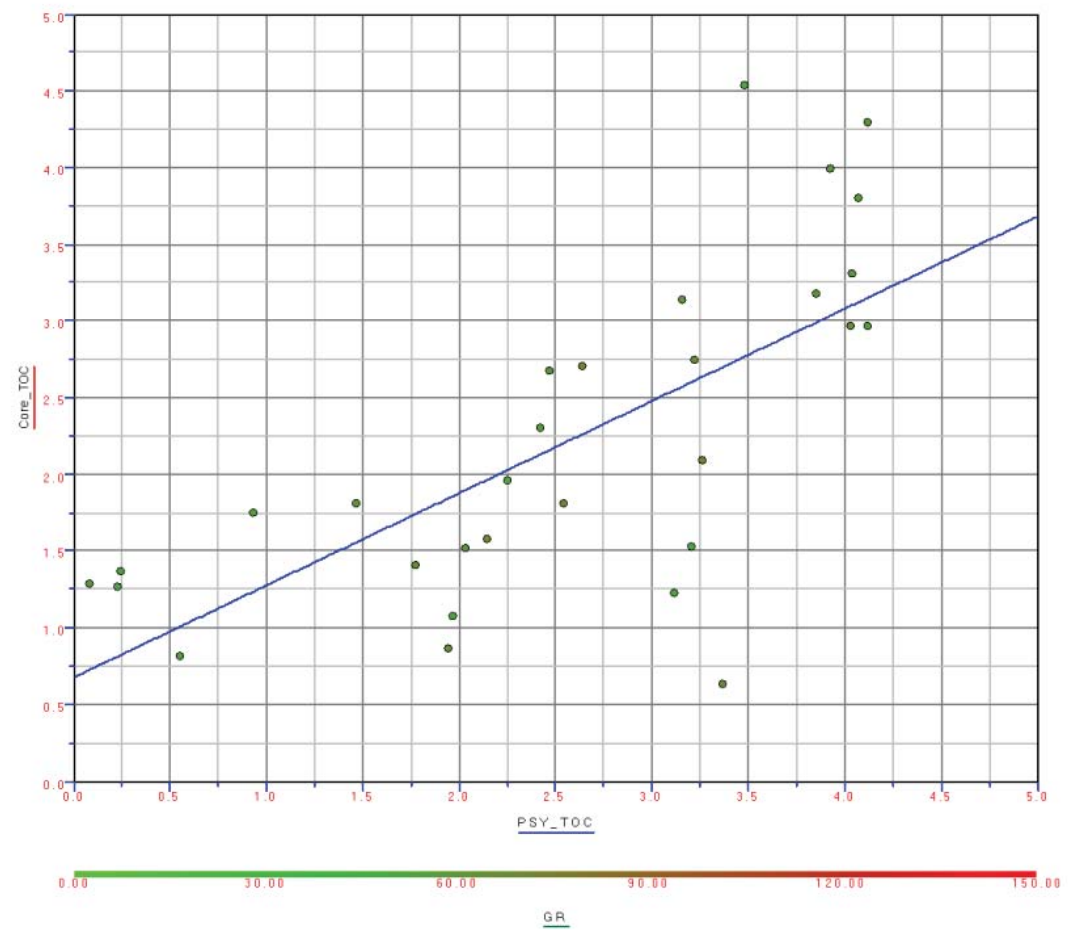

Figure 10.3: Core measured TOC against TOC calculated via Passey's method and resulting regression to indicate fit. JEM Bruggers 3-7 (API: 21-113-34078-0000), Missaukee County, MI.

Our thermal model takes depth into consideration to alter LOM in shallower, less mature regions as indicated by CAI data and expected (Hogarth and Sibley, 1985). Further work could be performed in order to develop a more accurate thermal model of the Michigan Basin based on publications from other authors (Cercone, 1984; Nunn et al., 1984; Vugrinovich 1989).

The results of mapping TOC values in the Collingwood across the Michigan Basin indicate that the Collingwood has the highest values of TOC in the northern part of the basin and the lowest in the more mature zones of the deep basin center. This is supplemented by core and outcrop data from this study and Canadian data from Manitoulin and St. Joseph islands (Macauley and Snowdon, 1984). 


\section{Geologic Model}

The Collingwood was deposited during the Middle to Late Ordovician. At this time Laurentia was situated along the equator and the Taconic Island Arc was converging with the continent resulting in orogenic development and tectonic subsidence (Keith, 1988; Stanley, 2005). Volcanism was prevalent as indicated by preserved metabentonite layers that are visible in the underlying Trenton Limestone from the Taconic Foreland Basin all the way into the Michigan Basin and across the Midwest (Delano, et al., 1990; Goldman, et al., 1994).

It has been suggested by several authors that there was a large carbonate platform of Trenton and Black River time that likely stretched from the Algonquin to Kankakee arch (Catacosinos et al., 1991; Wilson et al., 2001). It is further suggested that this platform was a product of rich carbonate production that kept pace with subsidence and sea-level rise resulting in thick sequences of deposition (Wilson et al., 2001). By examining a map of gamma-ray logs from the Trenton Formation we can see that the thickest deposits of the carbonate platform are in the south-eastern quadrant of the Michigan Basin near Sanilac and Lapeer counties (figure 11.1). We can also allude to the the overall character of deposition by the gamma-ray amplitude and signature.

The carbonate platform of the Trenton Formation and the Algonquin Arch have been studied by Wilson et al (Wilson et al., 2001) and Rancourt (Rancourt, 2009) respectively with no evidence of subariel exposure or shoaling found for either. Wilson et al propose an argument that water depth in the northern part of the Michigan Basin during the Trenton could be assumed to be "tens to $300 \mathrm{ft}$ " and that the absence of tidal flat facies suggests "some depth of water to permit open marine circulation over such a wide area" (Wilson et al., 2001). Additional evidence for deeper waters is provided by Rancourt in his identification of a species of deep, cold water conodonts present in the formation in the Canadian subsurface (Rancourt, 2009).

As one traverses from the south-eastern portion of the Michigan Basin to the northwest, both the Trenton and Black River formations thin relatively quickly. Wilson et al suggest that the northern area of the Michigan Basin during this time "coincides with the thick, subsident area of CambrianOrdovician deposition" (Wilson et al., 2001). Assuming deeper waters off a carbonate shelf suggests a carbonate shelf margin was present. Past this margin in the deeper waters, deposits in the Trenton have been noted to be thinner, darker in color, and generally have higher gamma-ray amplitude (figure 11.1) (Wilson et al., 2001). 


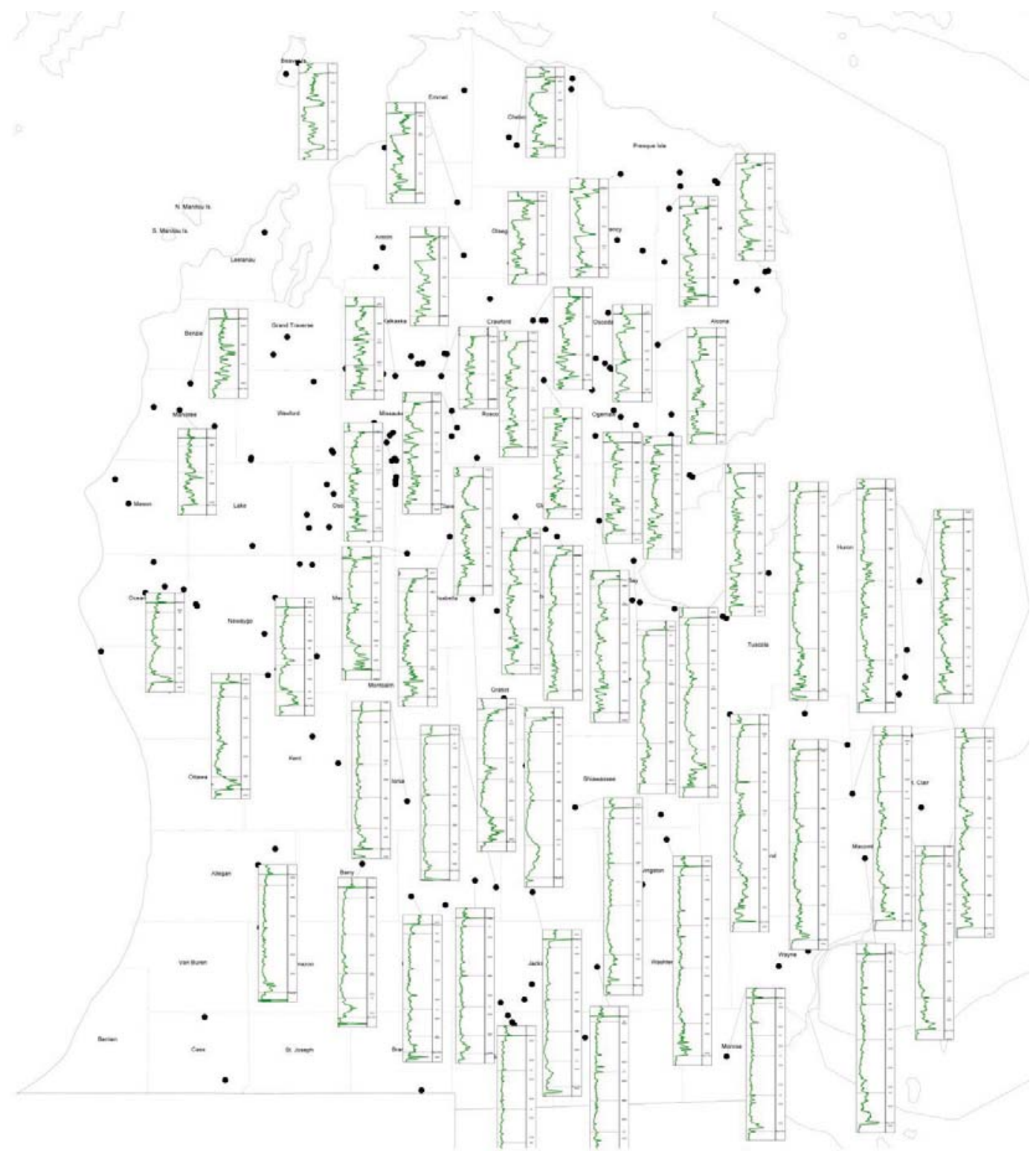

Figure 11.1: Gamma-ray logs from the Trenton Formation in the Michigan Basin. Log scale shown is 0-150 GAPI. Larger image shown in appendix (figure 14.1).

Examining stratigraphic cross sections of the Utica, Collingwood, Trenton, and Black River formations large scale trends across the Michigan Basin can be identified. In the following cross section of figure 11.2, the Utica Shale thins toward the south of the basin and has higher gamma-ray amplitude in the northern portion of the basin. The Collingwood is the only package in the group (Utica, Collingwood, Trenton and Black River) that thickens toward the north of the basin. It also develops higher gamma-ray amplitude in the northern part of the basin. The Trenton and Black River thicken toward the southeast with much lower gamma-ray amplitudes in the carbonate platform depocenter they share. 


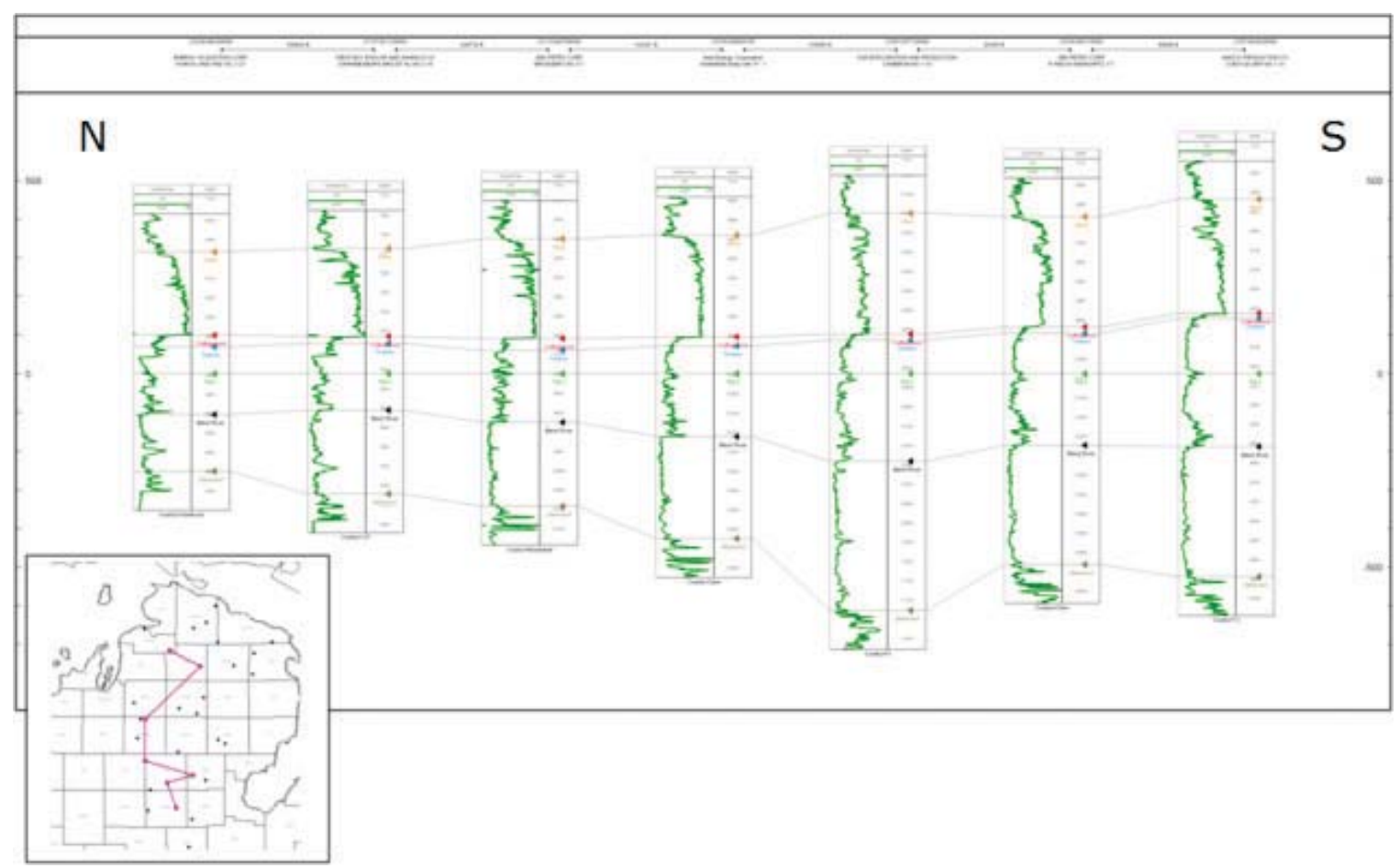

Figure 11.2: Stratigraphic cross-section as depicted by pink line shown. Cross section is leveled on TG-1 as datum. Picks for Utica Shale, Collingwood, Trenton, Black River, and Glenwood formation tops shown. Larger image in appendix (figure 14.2).

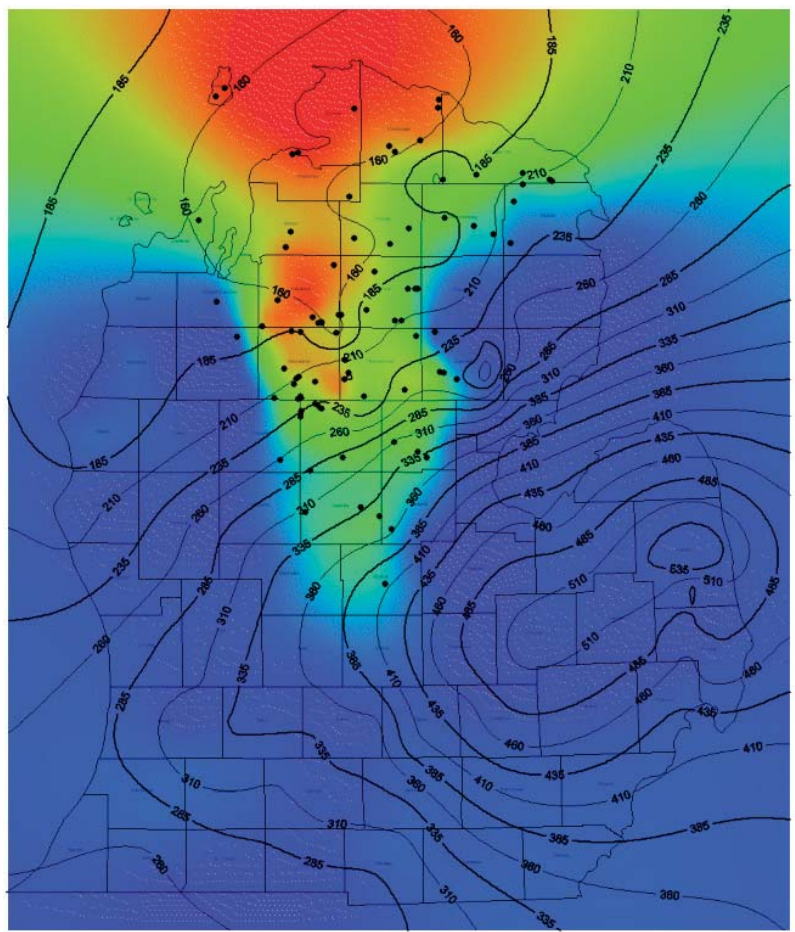

Figure 11.3: Collingwood isopach (colors) superimposed on Trenton isopach (contours). All displayed values measured in feet. Red represents maximum thickness. 
If we examine the Collingwood isopach map superimposed on the Trenton's (figure 11.3) we find that the majority of Collingwood deposition is over the thin Trenton deposits in the northern half of the basin. Note that the Collingwood deposition thins toward and ends near the carbonate platform of the Trenton. Not knowing the exact nature of subsidence and deposition during this time frame, we can only speculate that a carbonate shelf margin present in the Trenton, as suggested by Wilson et al (Wilson et al., 2001), would explain the southern termination of the Collingwood as a facies change. Well cores from Isabella and Gratiot Counties should show a shelf margin or slope facies in the Collingwood if this is the case.

The mechanism responsible for the east and west lateral extents of the Collingwood is unknown. One guess is a combination of subsidence and conformance to topographic highs in the basement structure of the basin. Specifically the midcontinental rift appears to flank the west extent of the Collingwood and the Grenville front, the east (figure 11.4). The Grenville front has been noted as being important in shaping Ordovician deposition patterns (Wilson et al., 2001). An eastward tilted profile of subsidence (Howell and Van Der Pluijm, 1999) combined with the Grenville front as a basement high (Wilson et al., 2001) may also have contributed to the east and west boundaries of the Collingwood.

The thickness of the Collingwood increases in the Michigan Basin when moving from south to north. This is a remarkable difference between the over and underlying sediment packages, specifically, the Utica Shale and Trenton Limestone, as they both trend in the opposite direction with depocenters in the southern portion of the basin. We believe that this is a key environmental indicator in developing a depositional model for the Collingwood. If we look at the underlying Trenton isopach and assume that it was laid upon a completely in-filled basin with no subsidence we end up a structure similar to that in figure 11.5. The actual profile of subsidence that the Collingwood would have been laid upon is unknown due to a sandstone fill-in (Fisher and Barratt, 1985) above the Sauk Sequence and the rapid accumulation of the Utica Shale (Wilson et al., 2001).

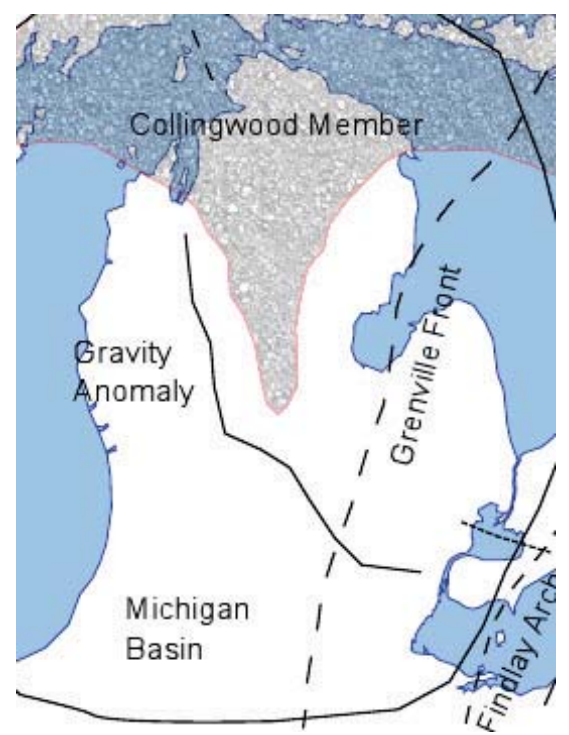

Figure 11.4: Structural features of the Michigan Basin that may be responsible for the deposition pattern of the Collingwood (shaded region). 


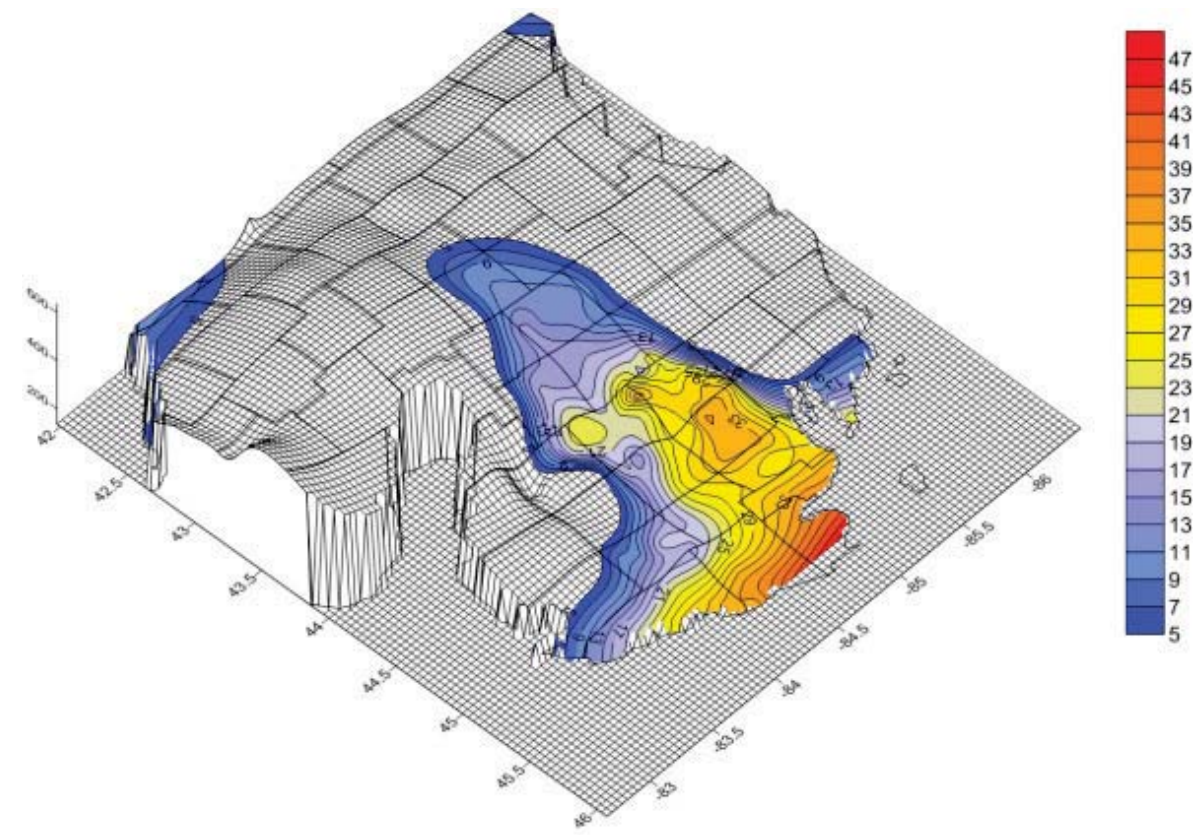

Figure 11.5: Collingwood isopach (colored contours) superimposed on Trenton isopach (wireframe). Both units measured in feet.

Post-Collingwood, the Utica Shale was deposited as the result of the Queenston delta and spillover from the filled Taconic Foreland Basin (Keith, 1988). The nature of the Utica is to increase in thickness toward the south of the basin. Howell and Van der Pluijm show that the basin-centered isopach pattern for the Utica Shale in the Michigan Basin does not necessarily imply basin-centered subsidence during this time frame, but "the infilling of an existing bathymetric low". Howell and Van der Pluijm also state that due to the lack of basin-centered subsidence the depocenters of the Trenton and Black River are shallow-water carbonate platforms (Howell and Van Der Pluijm, 1999). We do know however that the Michigan Basin's depression was shaped at this point due to sandstone accumulations in the depocenter from the Precambrian (Fisher and Barratt, 1985).

The mechanism responsible for the Collingwood's preservation of organic material is unknown. If we look at the facies in the Collingwood we see that the majority of the member consists of a dark, kerogen rich micrite. At times, there are occasional layers of fossil debris (previously suggested to be tempestites) that show up in the sequence but even these are still embedded in a dark micritic matrix. There is very little bioturbation present and fine, horizontal laminations that indicate a low energy environment.

One obvious conclusion to draw would be that the organic richness of the Collingwood might be related to an anoxic basin environment. It has been shown, however that "black shales" have been found deposited in open-ocean environments from large scale anoxic events (Hay and Cisne, 1988). Some of these black shales are nearby and chronologically correlatable to the Collingwood, specifically the Cynthiana-Pleasant Point shale in Ohio and Late Ordovician shales in the Taconic Foreland Basin. The shales in the Taconic Foreland Basin, previously thought to be related to conditions of limited basinal circulation have been re-evaluated (Hay and Cisne, 1988). Hay and Cisne suggest 
oxygen deficiency as a result of density stratification from climate change due to humid climate and poor water circulation due to a lack of polar ice caps (Hay and Cisne, 1988).

The most appropriate physical model for the Collingwood given the supporting information gathered is a carbonate shelf (Flugel, 2010). Along this shelf, a margin should exist past which a slope or distally steepened ramp. Flugel suggests that "a shelf break" exists to detect shelf margins. The shelf break is defined as a point where a significant change in gradient occurs. This transition may show a change from thick, light colored carbonates of the shelf, to dark, siliceous carbonates associated with deeper waters. The trend of the Trenton increasing in shale content and organic material in the northwestern quadrant of the basin has already been noted (Wilson et al 2001). Flugel describes basinal muds in his model as: (1) fine grained; (2) low energy; and (3) laminated. This matches the Collingwood very well as it has been observed.

A carbonate shelf model also gives a production and preservation mechanism for organic content. Near carbonate shelves, upwelling currents can occur which can bring nutrients from the deeper slope area to the surface waters. These nutrients then generate conditions favorable for high production of organic material by phytoplankton. This high level of productivity may result in depletion of oxygen in the deeper waters resulting in stratification and development of an anoxic bottom layer. This idea of upwelling has been suggested by other authors as well as a means of organic production and preservation (Harris, 1984; Churcher, et al., 1991). 


\section{Conclusions}

The Collingwood Member of the Trenton Formation in the Michigan Subsurface can be characterized as a very organic rich carbonate. Outcrop samples that were examined in this study, however, have not displayed this facies. They instead have very closely resembled the Trenton Formation in the subsurface of Grand Traverse County, MI, described by Hiatt (Hiatt, 1985). This difference may be attributed to an unresolved ambiguity concerning the outcrop exposures in Michigan's Upper Peninsula detailed in this study. Additional work should be performed in order to properly characterize the outcrops of the Collingwood in the Upper Peninsula.

Analysis of subsurface core samples and data provided by MGRRE show the Collingwood in the Michigan Basin to be an organic rich, microcrystalline limestone with very low permeability (1-13 md) and low porosity (2-4\%). Four unique facies were identified in Collingwood cores as: (1) a phosphatized hardground facies; (2) shell debris facies; (3) siliceous micrite facies; and (4) a homogenized variant of (2) and (3). Thin section petrography and SEM imaging characterize the nature of porosity in the Collingwood as microporosity located in the rock matrix with pore sizes ranging from 1 to 15 microns in diameter. No porosity was observed in embedded clasts.

XRD mineralogy analysis and SEM x-ray mapping indicate that the Collingwood is composed primarily of calcite, dolomite, silica, and clays. Further analysis of insoluble residue shows microcrystalline silica, illite, muscovite, iron chlorite, pyrite, and kerogen. Microscopy imaging of the insoluble residue and previous SEM imaging depict the physiological relationships of the mineral phases as kerogen deficient silica clasts and bladed plates of kerogen rich clay embedded in a kerogen rich micrite matrix. Difficulties experienced in the process of dissolving carbonate content in the Collingwood suggest that simple acid treatments may not suffice. In addition, the possibility of exploiting the silica components of the Collingwood as generated porosity through HCl-HF solution may be useful to increase porosity and permeability.

Pyrolysis data indicates that the Collingwood is thermally mature in the deep basin and produces dry gas and condensate. Additional examination of the thermal history of the Michigan Basin indicates an oil window approximately around the southernmost border of Antrim County. This is supplemented by production data from Cheboygan County indicating a liquid oil phase.

Chronostratigraphic correlation of metabentonites in the Trenton Formation through gamma-ray logs was successful in the south-eastern portion of the Michigan, but not in the north-western half due to higher background clay content and a much weaker correlation.

The petrophysical response of the Collingwood was studied in detail resulting in the mapping of its extents fully across the Michigan Basin. The Collingwood has been shown in wireline logs to be highly resistive with intermediate gamma-ray amplitude, high neutron porosity, low bulk density, and slow sonic velocities. Dipmeter logs were studied in an attempt to identify if natural fractures are present in the Collingwood. The results from dipmeter log analysis indicate that the data is unreliable and inconclusive. No natural fracturing of the Collingwood has been observed in core. 
The $\Delta \log R$ technique from Passey et al (Passey, et al., 1990) combined with linear regressions proposed by Bowman (Bowman, 2010) give a plausible method of identifying the Collingwood in wireline $\log$ suites and estimating values of TOC. A more robust thermal model and additional well core from the northern areas of the Michigan Basin could make this a very useful analysis tool to characterize TOC across broad regions.

Finally, data collected in this study and supplemental data from publications were used in order to construct a geological model for the Collingwood. Results indicate that it is likely that a carbonate shelf margin existed in the Trenton Formation and deposition beyond this margin is responsible for the thin, more argillaceous, and organic deposits in the north-western half of the Michigan Basin. The exact mechanisms that resulted in the shaping the Collingwood's deposit and production or preservation of its high organic content are unknown. 


\section{References}

Awdish, R.M. Wolverine Gold Rush? The Utica/Collingwood Shale Gas Play: Michigan's Answer to the Marcellus Shale. March 2011. http://www.pepperlaw.com/publications_update.aspx?ArticleKey=2057 (accessed Apr. 2011).

Barker, J.F. "Geochemical Analyses of Ontario Oil Shales." Open File Report, Ontario Geological Survey, 1985.

Bowman, T. "Direct Method for Determining Organic Shale Potential from Porosity and Resistivity Logs to Identify Possible Resource Plays." AAPG Search and Discovery Article 110128 (June 2010).

Brett, C.E., and W.D. Liddell. "Preservation and Paleoecology of a Middle Ordovician Hardground Community." Paleobiology Vol 4. No. 3, 1978: p. 329-348.

Carozzi, A.V. Sedimentary Petrography. Englewood Cliffs: PTR Prentice Hall, 1993.

Catacosinos, P.A., P.A. Daniels, and W.B. III Harrison. "Structure stratigraphy, and petroleum geology of the Michigan basin." AAPG Memoir 51 (1991): p. 561-601.

Catacosinos, P.A., W.B. III Harrison, R.F. Reynolds, D.B. Westjohn, and M.S. Wollensak. Stratigraphic Nomenclature for Michigan. Straigraphic Chart, Michigan Department of Environmental Quality Geological Survey Division and Michigan Basin Geological Society, 2000.

Cercone, K.R. "Thermal History of the Michigan Basin." AAPG Bulletin v.68 no. 2, 1984: p. 130-136.

Churcher, P.L., M.D. Johnson, P.G. Telford, and J.F. Barker. "Stratigraphy and Oil Shale Resource Potential of the Upper Ordovician Collingwood Member, Lindsay Formation, Southwestern Ontario." Open File Report, Ontario Geological Survey, Ontario, 1991.

Cochrane, R.O. "Evaluation of the Conventional and Potential Oil and Gas Reserves of the Ordovician of Ontario." Open File Report, Ontario Geological Survey, Ontario, 1984.

Cross, T.A., R.L. Dodge, J.C. Howard, and E.S. Siraki. Basin Analysis (Petroleum Geology GL804). IHRDC, 1995.

Delano, J.W., et al. "Petrology and Geochemistry of Ordovocian K-Bentonites in New York State: Constraints on the Nature of a Volcanic Arc." Journal of Geology, 1990: p. 157-170.

Fisher, J.H., and M.W. Barratt. "Exploration in Ordovician of Central Michigan Basin." AAPG BUlletin V. 69 No. 12, 1985: p. 2065-2076.

Flugel, E. Microfacies of Carbonate Rocks; Analysis, Interpretation and Application. 2nd Edition. Springer, 2010.

Folk, R.L. "Practical petrographical classification of limestones." AAPG Bulletin v.43, 1959: p. 1-38

Fox, E. Say Hello To The Collingwood Shale. May 2010. http://stocks.investopedia.com/stockanalysis/2010/say-hello-to-the-collingwood-shale-atls-eca-bbep-kwk0518.aspx (accessed Sept. 2010).

Glover, P.A. "Personal Webpage of Dr. Paul Glover." Petrophysics MSc Course Notes. 2000. http://www2.ggl.ulaval.ca/personnel/paglover/CD\%20Contents/GGL-

66565\%20Petrophysics\%20English/Chapter\%2012.PDF (accessed Jan. 2011). 
Goldman, D., C.E. Mitchell, S.M. Bergstrom, J.W. Delano, and S. Tice. "K-bentonites and Graptoilte Biostratigraphy in the Middle Ordovician of New York State and Quebec: A New Chronostratigraphic Model." Palaios V.9, 1994: p. 124-143.

Harris, D. "Graphic Logs of Oil Shale Intervals-Ordovician Collingwood Member and the Devonian Kettle Point and Marcellus Formations." Open File Report, Ontario Geological Survey, Ontario, Canada, 1985.

Harris, D. Straigraphy and depositional environment of the Collingwood Formation; a middle Ordovician oil shale from Ontario, Canada. unpubilshed thesis. Sudbury: Laurentian University, 1984.

Harrison, W.B. III. "Organic Shales and Fine-grained Organic Carbonates of the Michigan Basin Core Viewing Workshop." AAPG Eastern Section Annual Meeting. Kalamazoo, MI, 2010.

Harrison, W.B. III. "The Collingwood/Utica Shale in Michigan." Michigan Basin Insights and Field Experiences. Mt. Pleasant, MI, 2011.

Hay, B.J, and J.L. Cisne. "Deposition in the Oxygen-Deficient Taconic Foreland Basin, Late Ordovician." AAPG Studies in Geology; The Trenton Group of eastern North America; Deposition, Diagenesis, and Petroleum 29 (1988): p. 113-134.

Hiatt, C.R. A petrographic, geochemical, and well log analysis of the Utica shale-Trenton limestone transition in the northern Michgian basin. Thesis. Houghton: Michigan Technological University, 1985.

Hinks, A.W. "Gravity Anomalies Associated with Michigan Basin Dundee Formation Fractured Hydrothermal Dolomite Reservoirs and Implications for Exploration." Michigan Basin Insights and Field Experiences. Mt. Pleasant, MI, 2011.

Hogarth, C.G., and D.F. Sibley. "Thermal history of the Michigan basin: evidence from conodont color alteration indecies." Michigan Basin Geological Society Special paper 4 (1985): p. 45-55.

Howell, P.D., and B.A. Van der Pluijm. "Early history of the Michigan basin: Subsidence and Appalachian tectonics." Geology 18, no. 12 (December 1990): p. 1195-1198.

Howell, P.D., and B.A. Van Der Pluijm. "Structural sequences and styles of subsidence in the Michigan Basin." Geological Society of America Bulletin 111 (July 1999): p. 974-991.

Hussey, R.C. "The Ordovician Rocks of the Escanaba-Stonington Area." Michigan Basin Geological Society Publication Field Guide (1952).

Keith, B.D. "Regional Facies of Upper Ordovician Series of Eastern North America." AAPG Studies in Geology; The Trenton Group of eastern North America; Deposition, Diagenesis, and Petroleum 29 (1988): p. 1-16.

LeCompte, B., and G. Hursan. "Quantifying Source Rock Maturity from Logs: How to get more than TOC from Delta Log R." SPE Technical Paper, Society of Petroleum Engineers, Florence, Italy, 2010.

Lilienthal, R.T. Stratigraphic cross-sections of the Michigan Basin. Lansing: State of Michigan, Dept. of Natural Resources, Geological Survey Division, 1978.

Lucia, J.F. Carbonate Reservoir Characterization: An integrated approach. 2nd. Springer, 2007.

Luffel, D., and J Lorenzen. "Shale Evaluation New Albany Example RPSEA/GTI Project." Spring Topical Conference. Philadelphia, 2009.

Macauley, G., and L.R. Snowdon. "A Rock-Eval appraisal of the ordovician Collingwood shales, southern Ontario." Open File Report, Ontario Geological Survey, Calgary, 1984. 
MDEQ Online Oil and Gas Database. Permit 59919. Oct 2010.

Mehrtens, C. J. "Bioclastic Turbidites in the Trenton Limestone: Significance and Criteria for Recognition." AAPG Studies in Geology; The Trenton Group of eastern North America; Deposition, Diagenesis, and Petroleum 29 (1988): p. 87-112.

Passey, Q.R., S. Creaney, J.B. Kulla, F.J. Moretti, and J.D. Stroud. "A Pratcial Model for Organic Richness from Porosity and Resisitivy Logs." The American Association of Petroleum Geologists Bulletin, December 1990: p. 1777-1794.

Prouty, C.E. "Trenton Exploration and Wrenching Tectonics--Michigan Basin and Environs." AAPG Studies in geology 29 (1988): p. 207-236.

Quinlan, G.M. "Models of subsidence mechanisms in intracratonic basins, and their applicability to North American examples, in Beaumont, C., and Tankard, A.J., eds., Sedimentary basins and basin-forming mechanisms." Canadian Society of Petroleum Geologists Memoir 12, 1987: p. 463-481.

Rancourt, C.C. "Collingwood" strata in South-Central Ontario - A petrophysical chemostratigraphic approach to comparison and correlation using geophysical borehole logs. Thesis. Toronto: University of Toronto, Department of Geology, 2009.

Reed, R.C., and J. Daniels. Bedrock Geology of Northern Michigan: Geological Survey Division of Michigan Dept. of Natural Resources 1:500,000 scale. 1987.

Schlumberger. "Log Interpretation Charts." By Schlumberger Ltd., p. 184-185. 2005.

Sharma, S., G.R. Dix, and J.F.V. Riva. "Late Ordovician platform foundering, its paleoceanography and burial, as preserved in separate (eastern Michigan Basin, Ottawa Embayment) basins, southern Ontario." Canadian Journal of Earth Science Vol 40, 2003: p. 135-148.

Stanley, S.M. Earth System History. 2nd Edition. W.H. Freeman \& Co., 2005.

Tuffnell, P., and R. Ludvigsen. "The trilobite Triathrus in the Whitby Formation (Upper Ordovician) of Southern Ontario and a biostratigraphic framework, in Ontario." Open File Report, Ontario Geological Survey, Ontario, 1984.

Vugrinovich, R. "Subsurface temperatures and surface heat flow in the Michigan Basin and their relationships to regional subsurface fluid movement." Marine and Petroleum Geology 6, no. 1 (February 1989): p. 60-70.

Wilson, J.L., J.M. Budai, and A. Sengupta. Trenton - Black River Formations of Michigan Basin, AAPG Search and Discovery Article \#10020. 2001. http://www.searchanddiscovery.com/documents/trenton/index.htm (accessed Jan. 2011). 


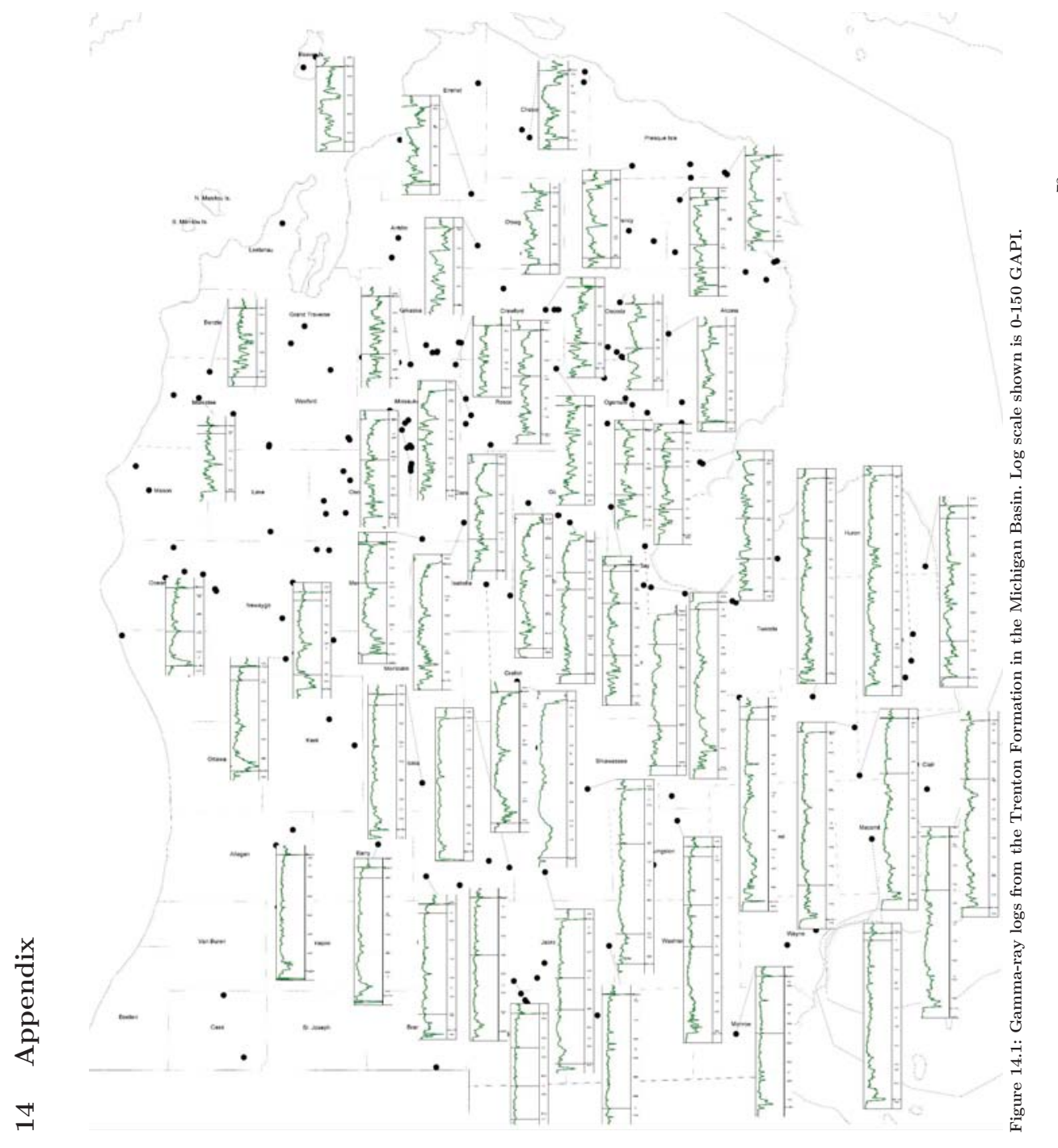




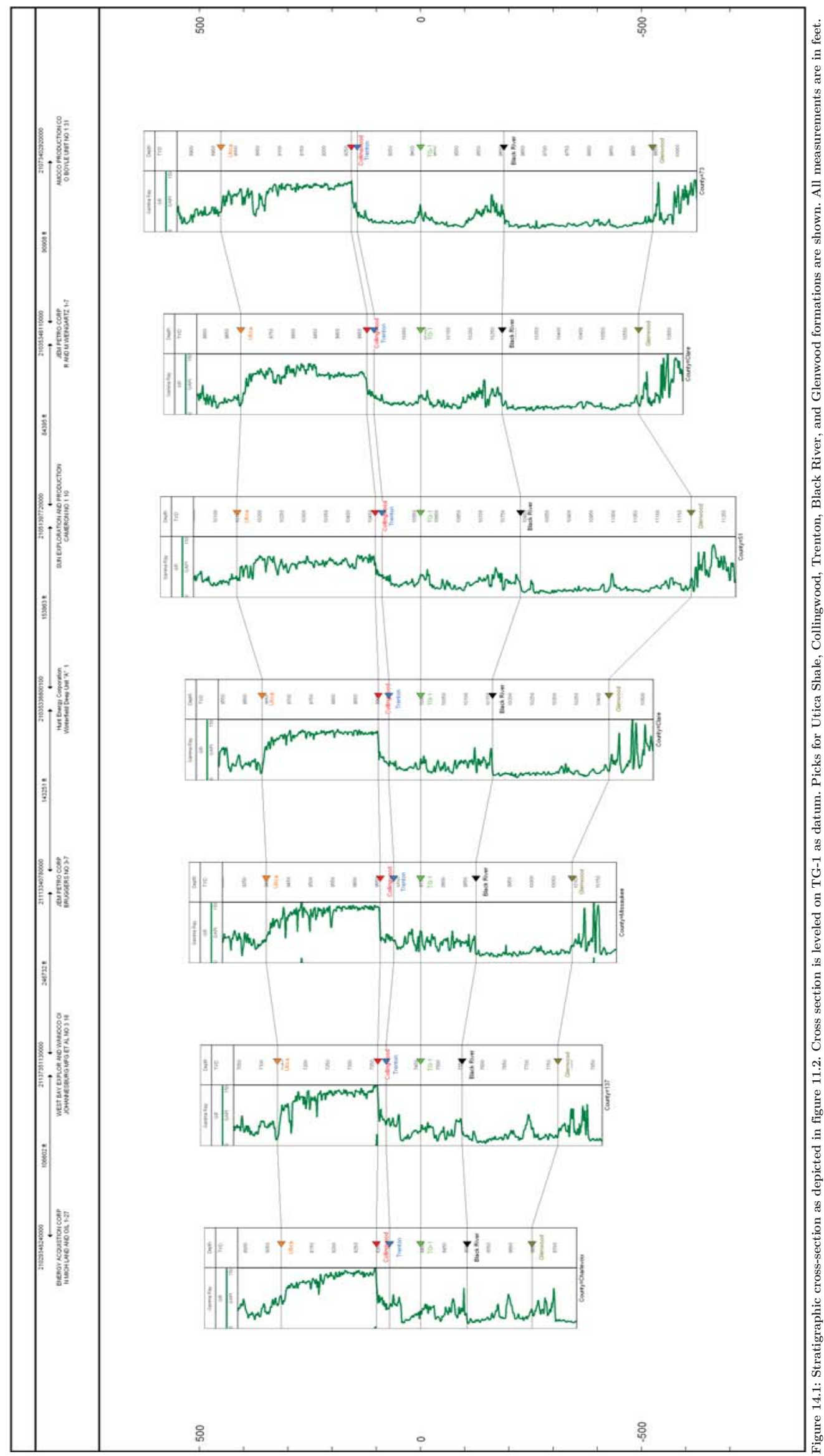

